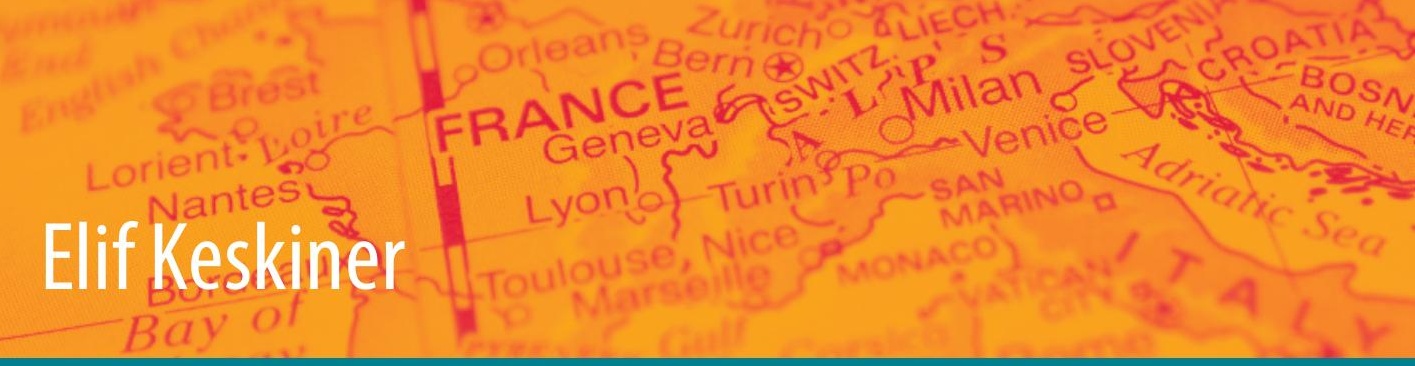

\title{
Youth Transitions among Descendants of Turkish Immigrants in Amsterdam and Strasbourg:
} A Generation in Transition 


\section{IMISCOE Research Series}


This series is the official book series of IMISCOE, the largest network of excellence on migration and diversity in the world. It comprises publications which present empirical and theoretical research on different aspects of international migration. The authors are all specialists, and the publications a rich source of information for researchers and others involved in international migration studies.

The series is published under the editorial supervision of the IMISCOE Editorial Committee which includes leading scholars from all over Europe. The series, which contains more than eighty titles already, is internationally peer reviewed which ensures that the book published in this series continue to present excellent academic standards and scholarly quality. Most of the books are available open access.

For information on how to submit a book proposal, please visit: http://www. imiscoe.org/publications/how-to-submit-a-book-proposal.

More information about this series at http://www.springer.com/series/13502 
Elif Keskiner

\section{Youth Transitions among Descendants of Turkish Immigrants in Amsterdam and Strasbourg:}

A Generation in Transition

黛 Springer Open 


\author{
Elif Keskiner \\ Department of Sociology \\ Vrije Universiteit \\ Amsterdam, The Netherlands
}

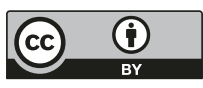

ISSN 2364-4087

ISSN 2364-4095 (electronic)

IMISCOE Research Series

ISBN 978-3-030-11789-4

ISBN 978-3-030-11790-0 (eBook)

https://doi.org/10.1007/978-3-030-11790-0

Library of Congress Control Number: 2019934344

(C) The Editor(s) (if applicable) and The Author(s) 2019, corrected publication 2019. This book is published open access.

Open Access This book is licensed under the terms of the Creative Commons Attribution 4.0 International License (http://creativecommons.org/licenses/by/4.0/), which permits use, sharing, adaptation, distribution and reproduction in any medium or format, as long as you give appropriate credit to the original author(s) and the source, provide a link to the Creative Commons licence and indicate if changes were made.

The images or other third party material in this book are included in the book's Creative Commons licence, unless indicated otherwise in a credit line to the material. If material is not included in the book's Creative Commons licence and your intended use is not permitted by statutory regulation or exceeds the permitted use, you will need to obtain permission directly from the copyright holder.

The use of general descriptive names, registered names, trademarks, service marks, etc. in this publication does not imply, even in the absence of a specific statement, that such names are exempt from the relevant protective laws and regulations and therefore free for general use.

The publisher, the authors, and the editors are safe to assume that the advice and information in this book are believed to be true and accurate at the date of publication. Neither the publisher nor the authors or the editors give a warranty, express or implied, with respect to the material contained herein or for any errors or omissions that may have been made. The publisher remains neutral with regard to jurisdictional claims in published maps and institutional affiliations.

This Springer imprint is published by the registered company Springer Nature Switzerland AG. The registered company address is: Gewerbestrasse 11, 6330 Cham, Switzerland 
To Deniz and Ada 


\section{Acknowledgments}

This book is the result of a 5-year PhD research effort where I had the luxury to go through an enduring experience of researching the lives of the descendants of Turkish migrants in Strasbourg and Amsterdam. During my research and throughout my experience of living in the Netherlands and France, I was always fascinated by their creativity to encompass and embrace various worlds into their being. To my understanding, by their mere existence, they continued to challenge all the boundaries that are invented and enforced upon us. I realized my interest in them did not stem from an identification issue as they were the natives and I was the migrant. I could only try to put myself in the shoes of their parents, who left their lives and families behind in Turkey with the hope that they will go back someday, a longing I myself now often endure. However, the second generation represented the future and their inspiring experience rendered questions of stay or return redundant. Hence I want to begin by expressing my gratitude to my respondents for inspiring me, opening their hearts and lives to me. I have learned so much from them, and I hope I have managed to do justice to their generosity.

I would like to thank my PhD promoters Prof. Maurice Crul, Prof. Manuela du Bois, and Prof. Jan Rath for their supervision and encouragement during my PhD research. The Institute for Migration and Ethnic Studies at the University of Amsterdam provided an academically stimulating but also a congenial working environment for me as a $\mathrm{PhD}$. Among many others, there I've met Maria Bruquetas, Manolis Pratsinakis, and Yannis Tzaninis, who have become great colleagues and dear friends, and I am so grateful that we continue to support and stimulate each other. TIES project introduced me to a great network of scholars where my special thanks go to Jens Schneider, Philipp Schnell, and Levent Soysal for their indispensable contributions.

Writing my dissertation into a book was another craft of understanding and writing. I realized how much I have grown as a researcher and an academic since the completion of my PhD. For that, I am indebted to Maurice Crul, who has been my inspirational mentor. Not only during my doctoral study but also after I have had the chance to work with him in various great projects such as Elites, RESL.eu, and now the BAM Project, and I have learned from him tremendously. I am very proud 
to have shared this learning experience with colleagues and friends from these projects: Ismintha Waldring, Sara Rezai, Frans Lelie, Talitha Stam, and Ali Konyali.

In preparing this manuscript, I am grateful to Anna Triandafyllidou and Irina Isaakyan from the editorial board of IMISCOE Springer for their ceaseless encouragement and assistance and the two anonymous reviewers for their constructive and meticulous reviews. A special thanks go to Liz Cross for her editorial work. All the responsibility for what is written herein lies with me alone.

I am indebted to my parents Asuman and Haydar Keskiner for their eternal support and belief in me. I am grateful to my in-laws, Delgen family, for their encouragement throughout the entire journey. My greatest thanks go to my love Levent, without whom none of this would have materialized. He was present since the first day of my $\mathrm{PhD}$, and before, and his existence was irreplaceable and invaluable. During the making of this book, a great transformation happened in our lives and our daughters Deniz and Ada joined us. Ada endured many of the book revisions in my belly and Deniz as a 2-year toddler, so they deserve a big applause. Since the beginning of this journey, Zeynep Tufekcioglu, Zeynep Yanasmayan, Zeynep Kasli, Isil Oztaysi, Nazli Senses, and Ozge Biner formed my greatest support group sometimes as dearest friends or colleagues and even some as mothers. Such women's solidarity has been crucial for my survival. Thank you all!

In writing this book, I have gone from being a researcher of second generation to being a parent of second generation. Now my husband and I, as migrant parents, are faced with various challenges that most of my respondents and their parents have gone through. The inspiring pathways of second generation in this book continue to encourage me and give endurance. I hope they also become an inspiration for my daughters, Deniz and Ada, to whom I dedicate this book. 


\section{Contents}

1 Youth Transitions of Descendants of Turkish Immigrants . . . . . . . 1

1.1 Youth Transitions .......................... 5

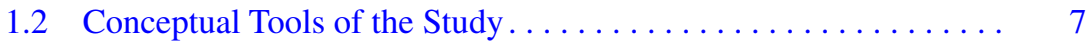

1.3 Case Selection and Methodology. . . . . . . . . . . . . . 13

1.4 Data Collection and Research Techniques.............. 18

References.............................. 21

2 Prolonged Transitions: Early Tracking and Its Implications for

Transitions ............................. 27

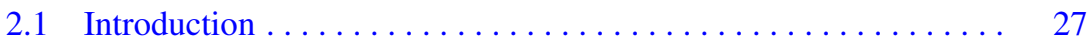

2.2 Stratification in Education Systems . . . . . . . . . . . . . 28

2.3 Transition Experience in Amsterdam and Strasbourg . . . . . . . . 36

2.4 Social Trajectories and Habitus; Experiences of Respondents in a Given Track and How the Track Shapes Them. . . . . . . . 46

2.5 Conclusion: Pre-conditioned Youth Transitions and the Role of Parents . . . . . . . . . . . . . . . . . . . . . . . . 48

References........................ 50

3 Blurring of the Transition Point: Combining Work and Study . . . . 53

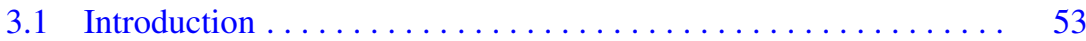

3.2 Structural Contexts for Student Employment in the Netherlands and France from 2005 to $2009 \ldots \ldots \ldots \ldots \ldots 5$

3.3 Work-Study Combination in Amsterdam and Strasbourg . . . . . . . 58

3.4 Conclusion: Implications of Work and Study Combinations. . . . . 72

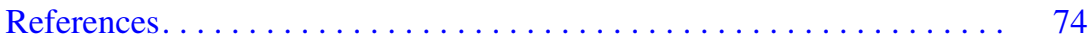

4 Transition Decisions: Intersections of Social Class, Gender

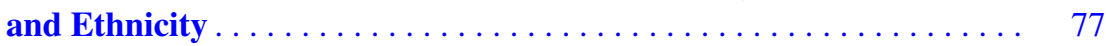

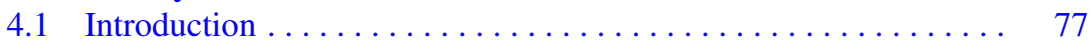

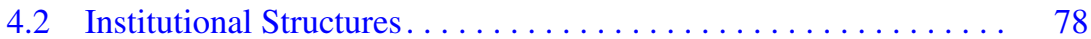

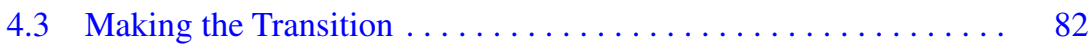


4.4 Conclusion: Gendered Pathways and the Role

of Family Support . . . . . . . . . . . . . . . . . . . . . . . . . . 101

References.................................... 103

5 A Typology of Transition Trajectories. . . . . . . . . . . . . . . . . 107

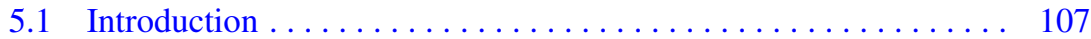

5.2 Transition Typologies in Previous Studies. . . . . . . . . . . . 108

5.3 A New Transition Typology. . . . . . . . . . . . . . 111

5.4 Refining the Transition Typologies: Qualitative Profiles. . . . . . . 120

5.5 Conclusion: Stable versus Shifting Transitions Among

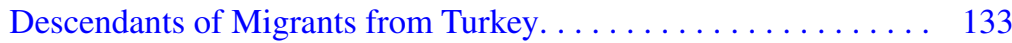

Appendix................................ 135

References............................... 136

6 Conclusion: Developing Forms of Capital in Youth Transitions. . . . . 139

6.1 Developing Forms of Capital Throughout the Transition Process . . . . . . . . . . . . . . . . . . . . . . . . . . 141

6.2 The Intersections of Social Class, Gender and Ethnicity in Youth Transitions . . . . . . . . . . . . . . . . . . . . . . 142

6.3 Comparative Research Design: Amsterdam and Strasbourg . . . . . . 144

6.4 Possible Future Avenues of Research and Policy Implications . . . 145

References......................... 146

Correction to: Youth Transitions among Descendants of Turkish

Immigrants in Amsterdam and Strasbourg:

The original version of this book was revised. This book was inadvertently published with incorrect affiliation of the author "Elif Keskiner". It has now been updated as: Department of Sociology, Vrije Universiteit, Amsterdam, The Netherlands. The correction to this chapter is available at https://doi.org/10.1007/978-3-030-11790-0_7 


\section{Chapter 1 \\ Youth Transitions of Descendants of Turkish Immigrants}

Writing this, I am sitting at a table in the library of a tertiary vocational school in Zwolle, a medium size Dutch city. I am surrounded by the descendants of immigrants from Turkey. They have no idea I am writing about them, much less that I understand, and admire, how they are talking in a creative half-Turkish half-Dutch argot. I catch their discussions, which are about everything ranging from the exams next week to the annoying boss at a bijbaan ${ }^{1}$; from worries about finding an apprenticeship to Turkish TV heartthrob Kıvanç Tatlıtuğ's acting in last night's episode; from the latest iPhone features to plans for next summer's holiday in Istanbul; plus a whole lot of gossip about friends in between. Listening in on these conversions, I cannot help but wonder why doubts about these young people's integration dominate current public debates rather than questions about their daily realities: the obstacles that they encounter at school and on the labour market; how they navigate these barriers and how they negotiate the multiple frames of references that enrich their lives. This book seeks to answer these questions, which have indisputable present-day urgency though actually began being asked decades ago.

In 1980, Gündüz Vassaf, a prominent Turkish scholar of psychology, spent a sabbatical in Europe, first in the Netherlands and then in Germany and conducted one of the first studies on the children of immigrants, the findings of which he published in the book Daha Sesimizi Duyuramadık: Avrupa'daki Türk Işçi Çocuklarl. ${ }^{2}$ The title was inspired by something a descendant of a Turkish immigrant told him: "We are not a lost generation, nor are we stuck in between; we just haven't had our voices heard." Vassaf called attention to the problems that children of Turkish immigrants were facing and warned that negligence by both host and home countries would have serious consequences for the futures of these

\footnotetext{
${ }^{1}$ Dutch for 'side job'.

${ }^{2}$ We Still Couldn't Make Our Voices Heard: The Children of Turkish Workers in Europe (Vassaf 1983).
} 
individuals. His study was unique in highlighting the perspectives of immigrants and their children rather than the worries of the host countries or home societies.

Nearly 40 years later, the descendants of immigrants are at the forefront of public debate, garnering attention not only in social science research, but also in government policies and the media. However, in many Western European countries, the public discourse reflects a population largely deaf and blind to the concerns and struggles of these young people, still seeking to apportion blame for their perceived lack of integration. Media reports on integration emphasize the lower educational attainment and higher unemployment rates among the descendants of immigrants, and even overgeneralize some groups' involvement in criminal activities. Negative labels such as 'immigrant', 'ethnic', 'allochtoon' and 'foreign' cast these youth as outsiders, even when they are native-born citizens of their host countries. Considered in this light, the debate around integration appears to mask a systemic unwillingness and/or inability to meet the needs of immigrants and their descendants and embrace their realities; instead, it superficially frames observed inequalities in terms of these groups' own attitudes or deficiencies. With Islamophobia recently dominating public and political discourses, descendants of immigrants from Muslim-majority countries, such as Turkey, also suffer as subjects of suspicion. This has been amplified in the populist discourse of extreme right-wing parties, which have regained political traction in Europe in recent years.

As highlighted by Crul and Schneider (2010), the descendants of immigrants are the new natives of the cities into which they are born and raised. Their numbers are growing and they are transforming the mainstream constitutions of a super-diverse metropolitan world (p. 1257). During the last two decades, considerable research has examined the social and institutional realities faced by the children of post-war immigrants born and raised in various European countries and the United States (Kasinitz et al. 2008; Levitt 2009; Crul et al. 2012; Crul and Mollenkopf 2012). Among these groups, the native-born descendants of Turkish immigrants have been receiving plenty of attention since the early 2000s due to their widespread presence in various European countries (Caglar 1998; Kaya and Kentel 2005; Soysal 2001; Kastoryano 2002; Crul and Vermeulen 2003). Today, Turkish immigrants and their descendants are one of the largest ethnic minorities in Western Europe, and comprise a population of up to eight million people.

From the outset, the case of Turkish migrants has been considered ideal for cross-country comparison as guest-worker migration to various locations occurred around the same time (Crul and Vermeulen 2003). Pioneering comparisons included Kaya and Kentel (2005) who contrasted the integration pathways of Turkish migrants and their descendants in France and Germany and uncovered the role of different citizenship regimes and the host society's institutional structures in shaping the integration outcomes. Another classical study by Kastoryano (2002) dissects the dynamics between state policies in France and Germany and immigrants' demands, focusing on immigrants of North African origin in France and Turkish immigrants in Germany. Such comparative studies began to highlight the role of state policies and express the identity and recognition concerns of Turkish immigrants across different settings. 
Turkish second-generation youth have also become an interesting focus group for social stratification research regarding their experiences in education and labour market settings. In general Turkish second-generation youth have been found to perform worse than their peers with native-born parents, mostly due to their parents' lower education levels. Nevertheless their performance varied across distinct institutional settings in Europe (Crul and Vermeulen 2003). Heath et al. (2008) showed that native-born descendants of Turkish immigrants in Belgium, the Netherlands and Germany performed worse in terms of educational outcomes compared to their peers with native-born parents; however, in the Netherlands and Germany, they attributed this to parental (lower) social class. Schnell (2012) provided a systemic explanation and showed that this group performed better in more comprehensive systems, such as those in France and Sweden, than in stratified systems, such as those in Germany and the Netherlands. Regarding meso-level explanations, Rezai and her colleagues (2015) disclosed the role played by parents and significant others in educational mobility and showed how parents (despite lower education levels) could provide different forms of support which turned out to be influential. Keskiner (2015) displayed that parents deployed varying strategies to influence their children's education across distinct education systems; in countries like the Netherlands where their impact is restricted by the system, they could exert less influence on their children's tracking choices. In Switzerland, Schnell and Fibbi (2016) found that young adults of Turkish and Western Balkan origin were more likely than their peers of native origin to be upwardly mobile in the education system (as opposed to starting high) and that parental monitoring and family cohesion played a significant role in regard to upward mobility.

It has also been shown that descendants of Turkish immigrants are affected by poorer labour market progression and higher rates of unemployment even when education levels have been controlled for in France (Simon 2003), Germany, the Netherlands, Sweden, Belgium, Switzerland and Austria (Lessard-Philipps et al. 2012). These trends have persisted for many years in various countries. Using data from the first wave of the 'Netherlands Longitudinal Life-Course Study' (20092010), Gracia et al. (2016) tested the ethnic penalty argument for second-generation Turks and Moroccans in the Netherlands, taking into consideration not only schooling but also skills and social origins and found that ethnic penalties persist for Turkish second-generation migrants. For example, women of Turkish origin had a higher likelihood of being unemployed even after controlling for education, social origin and skills (ibid). Analyzing two waves of panel data, including a more recent wave, Witteveen and Alba (2018) have shown an increasing employment disadvantage for second-generation Turks and Moroccans and persisting ethnic penalties in hiring processes: after controlling for education background and demographics they found that the youngest cohorts of the second generation were significantly less likely to find employment compared to their peers with native-born parents. Hence the most recent studies showed that difficulties in finding employment after school continue to persist. 
Another strand of emerging research examines the "successful" group within the Turkish second generation, thereby emphasizing that the entire group cannot be categorised as disadvantaged (Crul et al. 2017; Waldring et al. 2015; Schneider and Lang 2014; Keskiner and Crul 2017; Vermeulen and Keskiner 2017). Studies pursuing a more qualitative approach have identified the roles of institutional structures in education and the labour market in shaping the upward mobility of descendants of Turkish immigrants (Keskiner and Crul 2017; Konyali 2017). While successful in uncovering the mechanisms to achieve higher education levels, this stream of research does not account for those individuals who do not achieve upward mobility, nor the type of support mechanisms available (or not) to them. A more diverse sample would be needed to uncover the mechanisms that lead to different trajectories through and out of education, as well as into and in the labour market.

My own contribution to this debate is to provide a comparative analysis on the youth transitions of descendants of migrants. Previous studies have shown the relevance of cross-country comparisons in revealing the roles played by institutional structures, but these have mostly relied on survey data. Combining quantitative methods with qualitative research can help to detect the processes and mechanisms that can explain these general statistical trends. Previously, young people of Turkish origin have been studied within the cultural domain, for example hip-hop culture in Berlin has received considerable attention (Caglar 1998; Soysal 2001). Soysal's study shows that while the general public is wallowing in senseless integration concerns, young people of Turkish origin have become active participants and producers of youth culture in Berlin (2001). As inhabitants of Berlin, they "contribute to the constitution of the city as a diverse, cosmopolitan metropolis in the new Europe" (Soysal 2001, 22). Such studies are crucial to giving a voice to the experiences of second-generation youth. In a more recent study Celik (2015) studied reinforced ethnic identity when faced with perceived discrimination and the experience of "systematic devaluation of ethnic culture"(p. 13). His study is valuable in making a connection between social disadvantage in education and the labour market and ethnic identification and in showing how the two are connected. The negative experiences of Turkish-origin youth in Germany and the effect of reactive ethnicity is very much in line with the recent trends on educational and labour market disadvantage.

To fill an existing gap in research on the education and labour market experiences of the Turkish second generation, ${ }^{3}$ I cover a more diverse sample and use mixed methods. Studies on youth transition put young people front and centre. The analyses emanate from the young people themselves, exploring reality from their perspective and bringing to light their relationships with society at large and its structures. Pursuing an outcome-oriented approach, social stratification research illustrates the disadvantaged position held, in general, by descendants of Turkish immigrants; youth studies concentrate on the processes leading up to such outcomes. As such, youth studies help generate self-serving research tools and theoretical concepts for understanding the complex lives of young people today.

${ }^{3}$ Throughout the book I use the terms "Turkish second generation", "native-born descendants of Turkish immigrants", "descendants of immigrants from Turkey" interchangeably. 


\subsection{Youth Transitions}

Current labour market conditions have caused youth unemployment to skyrocket and insecurities in the labour market careers to intensify. The effects have been hardest on young people who are about to leave school and enter the labour market (Furlong 2009). This transition marks a critical point in the lives of young people. Traditionally, the transition has been considered to be the period "from the completion of full time education to entering into the labour market with a full-time job" (Mueller and Shavit 1998). In the last two decades, youth studies have promoted a new take on 'transition', moving away from its conceptualization as a single point in an individual's biography towards an analysis of the dynamic interplay between multiple transitions that take place simultaneously (du Bois-Reymond 2009a). Today, young people leave their parental home and have children before getting married; they begin working while still at school and may go back to school after having worked for some time and started a family. There is no longer a clear-cut boundary or temporal linearity between work and study (du Bois-Reymond 1998; Wyn and Dwyer 1999). Accordingly, youth sociologists argue that these transitions have become prolonged and more complex (Furlong 2009). One major reason cited for this prolongation is the rising demand for credentials to satisfy the 'knowledge economy' of most Western European countries, compelling individuals to stay in school for longer and delaying their labour market entry (Bradley and Devadason 2008; du Bois-Reymond 1998).

The prolongation of education not only postpones entry into the labour market, but also leads to more complex transitions. The conceptualization of the "transition point" is becoming more and more blurred as people start jobs while still pursuing an education or return to school after having begun to work (Heinz 2009; Wyn and Dwyer 1999). Prolonged and complex transitions also affect perceptions of life course and age. The point of labour market entrance sways conventions about the acceptable age to be considered independent: in most Western European countries, young people are also delaying getting married and having children (Willoughby et al. 2015). Heinz (2009) wrote that "borders between all life phases are becoming fuzzy"; that age as a social marker is losing its significance and that transitions between certain life courses are less age-dependent and show greater variation across individuals, groups and countries.

Many researchers acknowledge the "changing" nature of youth transitions (Bradley and Devadason 2008; du Bois-Reymond 2009b; Furlong 2009; Heinz 2009). Yet, there remains room for discussion about the implications and consequences of these transformations on the lives of young people and whether they apply to all social classes and backgrounds. Tensions tend to arise around the interplay between structure and agency during transitions. Theories forwarded by Beck (1992) and Giddens (1991) have been influential in spurring debate on the individualization of youth transitions (du Bois-Reymond 1998; Evans and Furlong 1996; Furlong 1998). Beck (1992, 2007) argued that insecure labour market conditions, such as unemployment and precarious job contracts, generate a "risk society" in 
which people must "navigate" their biographies: this produces greater individualization in life practices and diminishes the significance of, and attachment to, forms of collectivity, such as social class, gender, marriage and family. In a similar vein, Giddens (1991: 72) observed that individuals are increasingly forced to be conscious of who they are, what they want and what they feel, thus becoming 'the authors of their own autobiographies': this renders them responsible for a "reflexive" process of building "themselves". In life course studies, a life phase called "emerging adulthood" (Arnett and Tanner 2006) has gained prominence. This identifies a developmental stage between adolescence and adulthood and acknowledges that young people nowadays have more agency in navigating their biographies regardless of their social class, gender or ethnicity.

Such arguments that attribute greater agency to young people have their critics. Various scholars argue that today's youth transitions are due to structural transformations, notably post-industrial economies in Western Europe, the booming service economy and growing neoliberal practices in both education and the labour market—none of which necessarily result in increased agency (Furlong 2009). Furlong and Cartmel (1997) found that while the rising role of agency has become more evident in youth discourses, inequalities along the lines of social class, gender and age have persisted. Studying early labour market careers in Bristol, Bradley and Devadason (2008) posited that non-traditional transitions were the result of economic insecurities, rather than young people's own decisions to "navigate" their biographies in line with Beck (1992). Last but not least, Côté and Bynner (2008) and Côté $(2014 \mathrm{a}, \mathrm{b})$ argued that the phenomenon of prolongation has been around longer than many people might think, and that it varies across countries and groups. Lacking empirical proof to make generalizations, they therefore oppose "emerging adulthood" as a universally applicable label. Citing evidence from Canada, Côté and Bynner (2008) emphasize the influence of structural changes, particularly technological transformations and economic globalization. They note that the responses to these changes is neither uniform nor universal, but varies according to social class and local conditions. While some individuals prolong their transitions into higher education, others obtain few educational qualifications and leave school at an early age to start work. Although a higher sense of risk and uncertainty has intensified young people's reliance on social support mechanisms and their families, the extent to which they do so varies across settings. Côté $(2014 \mathrm{a}, \mathrm{b})$ has called for a perspective based on the " "political economy of youth" that pays more attention to material conditions than to subjectivities. He argues that young people are faced with considerably reduced earning power in comparison to adults and have become disadvantaged "as a class". He urges researchers to pay attention to the structural conditions of youth transition and the differences among this group along the class, ethnicity and gender lines that continue to shape their chances. A perspective that is also taken on board in this study.

The research presented in this book not only puts an understudied group under the microscope, but also challenges some of the assumptions that have dominated-and perhaps also clouded - youth transition studies over the last decade. To understand the youth transitions of descendants of Turkish immigrants, we must see which 
trends apply to them and under what conditions. In fact, we must ask whether they do experience prolonged and complex transitions. And, if so, how? Delving more deeply, we can then ask if the descendants of immigrants are also delaying transitions (such as by postponing marriage), and examine the role played by gender, ethnicity and social class. Can these young people still rely on their family for support during transitions if they come from lower social classes, if their parents have relatively low education levels and a different ethnic background? Furthermore, how might gendered values in their ethnic community shape their transitions? At what age and under what conditions are transitions acceptable for second-generation youth?

Previous studies have presented the transition pathways of ethnic minority youth as different from those of the majority group, yet have struggled to interpret these trajectories due to insufficient ethnic minority data (Evans 2002; Lehmann 2007; Plug and Bois-Reymond 2006). For example, Plug and Bois-Reymond (2006) filed young Roma women's trajectories under 'other transitions' since they married and had children earlier than the general population, although the processes or mechanisms that led to such transitions were not scrutinized. Other studies stressed unequal conditions, especially when discussing the transitions of 'ethnic minority youth' (Evans 2002; Evans and Furlong 1996; Lehmann 2007; Plug and BoisReymond 2006; Webster 2009). That term, however, lumps together both immigrants and their descendants, regardless of whether they were born in the host country or a parent's country of origin. Although researchers have often emphasized the discriminatory practices and unequal resources such groups must contend with when transitioning from school to work, not enough attention has been paid to social class, gender and ethnicity, and how those factors shape transitions of immigrants' descendants in different contexts.

This book explores when and how having immigrant parents influences young people's transitions in different settings. Broadly speaking, it scrutinizes social structures to determine how they shape transition outcomes. It shows how immigrants' descendants experience unique conditions and how their youth transitions differ from those of others, due to their ethnic community's gendered values and their parent's resources, often circumscribed by social class and ethnic background. The book uses a comparative design to highlight how social structures interact with institutional structures to present these young people with both opportunities and obstacles during their transitions.

\subsection{Conceptual Tools of the Study}

In analyzing youth transitions as both forms of practice and on-going processes in young people's trajectories, I borrow some concepts from Bourdieu while also staying critical of his theory. Capital theory helps to order the social background of descendants of Turkish immigrants by exploring the forms of capital and resources they possess in relation to different fields. This is innovative since Bourdieu (1984) applied capital theory to study social reproduction among an advantaged middle 
class; I look at how forms of capital can be used to comprehend the reproduction of social disadvantage as well as ways of overcoming such disadvantage and become upward mobile. Migration and ethnic studies have mostly employed the concept of "capital" in terms of social capital. Zhou (2005) used the concept as "ethnicity as social capital", a resource embedded in the Chinese ethnic community and Modood (2004) examined it as a resource embedded in the Pakistani community in the UK. These studies mostly looked at one dimension and operationalized capital as an asset in the community rather than a process that could be activated across the life course. This is mostly because they have used the "capital" as an embedded resource rather than studying forms of capital as a developmental concept in one's social trajectory, which is where the innovative approach of this study lies. Taking into account social class, gender and ethnicity as main social structural dimensions; I study how different forms of capital, or the lack thereof, influence peoples' transition trajectories.

\subsubsection{Social Class: Parents' Forms of Capital}

One of the most common lenses through which to see and evaluate social class is occupational status (Crompton 2010). Most studies of educational achievement among the descendants of immigrants use variables that combine occupational status with educational level to control for the effect of parental background (Heath and Brinbaum 2007). Other studies take parental resources into account to help explain the role that parents play in educational attainment (Crul et al. 2012; Schnell 2012; Van de Werfhorst and Van Tubergen 2007). These studies repeatedly analyse and affirm the role of parental background and involvement in educational attainment. When controlling for parental background Van de Werfshorst and Van Tubergen (2007) found that the descendants of immigrants appeared more likely to succeed than those with native-born parents. Brinbaum and Kieffer (2009) showed that French immigrant parents had higher aspirations for their children than nativeborn parents with similar educational and occupational backgrounds. These studies highlight how, despite apparent similarities in education and economic status among immigrants, there are covert mechanisms and/or resources that significantly differentiate immigrant parents from each other and from native-born parents. Furthermore, youth transition research, still mostly entrenched in the individualization paradigm, can benefit from examining how parental social class influences transition processes. Although recent studies have found that economic insecurities force young people to rely more on family support mechanisms (Cote and Bynner 2008; Jones 2009), they do not specify which kinds of support are significant.

To capture the covert mechanisms of social class in young people's lives, I apply a more detailed class analysis. Savage et al. (2005) proposed that by employing concepts such as capital, assets and resources (CARs) —notably including Bourdieu's forms of capital-we might derive a better understanding of how class inequalities are formed at the micro-level. This approach is conducive to comprehending how 
social class works in practice rather than merely constructing a classification scheme. Savage et al. (2005) credited Bourdieu for providing a dynamic conceptualization of class due to the potential for accumulating or transforming various forms of capital.

For Bourdieu (1985b, 1987), social class is a social space where agents are distributed according to their relative capital and have the opportunity to share a similar habitus. Bourdieu (1985a) proposed four generic forms of capital: cultural, economic, social and symbolic. Capital comprises the material and non-material resources with which individuals are endowed for their struggle in different fields (Bourdieu 1985a). It is thus important to establish the relationship between capital and a field that bestows a symbolic value on it. For Bourdieu (2005: 44), the latter refers to "a field of forces and struggles in which the stake is the power to transform the field of forces". In each field, struggles transpire between "the newcomer who tries to break through the barrier and the dominant agent who will try to defend the monopoly and keep out the competition" (p. 72). The conditions apply to all fields, including politics, religion, education and employment. It should not be forgotten, that the descendants of immigrants are newcomers to many fields where the rules of game are already set.

Forms of capital are not fixed, and their convertibility is a cornerstone of the theory; the forms can develop along the course of a social trajectory and convert into one other. They let us study social class dynamically, as a constant struggle wherein individuals develop and convert various resources in their social trajectories, rather than as a fixed status. Because Bourdieu (1984) initially used forms of capital to study the social reproduction of advantage among the dominant group, he is often criticised for being a theorist of reproduction rather than of change and transformation (Bennett et al. 2009; Friedman 2016; Jenkins 2002). Yet, migration scholars have used his theoretical toolkit to illustrate capital development (Keskiner 2015, 2017; Keskiner and Crul 2017) and intra-group variations of capital acquisition and production (Erel 2010). Erel (2010) showed how, over time, migrant women have developed different forms of capital in their migration trajectories and selectively turned to resources from their home country. In line with her argument, I study the differentiation of capital among immigrant parents to see how it impacts their children's social trajectory, beginning with their education and into their transitions. Despite mostly originating from rural backgrounds in Turkey, the immigrant parents in my study experienced distinct institutional structures in their host countries and wide variations with regard to language acquisition, educational attainment, labour market conditions and exposure to migrant and/or family networks. I hypothesized that this would lead to capital development and conversion among the parents, that might not be directly captured by the statistical models controlling for their "educational level". Erel (2010: 643) stated that forms of capital are "both the product of and productive of differentiations of gender, ethnicity and class within the migrant group". To her list, I therefore add age and generation. Intra-migrant group differentiations of capital development also show variations across age and the generation of migration, since migrants are exposed to different structures at different times. 
To reiterate, I analyze migrant parents' forms of capital expressly in relation to their children's trajectories. Yet, this book's major contribution is to explain how the descendants of Turkish immigrants develop forms of capital in their social trajectories and how they do so across two distinct settings.

\title{
1.2.2 Social Class in the Making: Developing Forms of Capital Along Social Trajectories
}

In his book Distinction, Bourdieu (1984: 109) discusses the concept of social trajectory.

\begin{abstract}
On the one hand, agents are not completely defined by the properties they possess at a given time, whose conditions of acquisition persist in the habitus (the hysteresis effect); and on the other hand, the relationship between initial capital and present capital, or, to put it in another way, between the initial and present positions in social space, is a statistical relationship of very variable intensity.
\end{abstract}

In this definition, Bourdieu suggests that individuals travel along a trajectory and they can, over time, diversify and augment their capital. Nevertheless, he argues, the available pathways and the trajectory one travels depend on one's initial social position. The trajectory's slope will thus be determined by parental resources and position in social space, and the capital available at the end of the trajectory will strongly correlate with initial parental capital. That is to say, young people do not move randomly in social space; their trajectories are structured by institutional settings, contextual factors and their parents' resources. Yet, as Bourdieu (1999) later observed in The Weight of the World, educational systems have become major markers of success and can, to a great extent, affect students' chances to succeed in life. In my study, a social trajectory is not restricted by parental background, and each structure has its own ways of shaping trajectories. In relation to these diverse structures, young people can develop various forms of capital, which may or may not facilitate achieving greater distance from their parents' initial position in social space. Bourdieu's social trajectory was also popular in youth transition studies in the 1980s, although came under fire for its structuralist emphasis. Revisiting the concept, my study argues that even though young people navigate their own transitions - and hence execute agency - their transitions are still bound by social and institutional structures.

In sum, my application of Bourdieu's theories is both flexible and reflexive. On one hand, I use his concepts to articulate the relationship between capital and fields. On the other, his concept of social trajectory allows me to demonstrate that not all trajectories travelled by the descendants of immigrants reproduce their initial conditions. Understanding social trajectories is crucial to understanding the transitions of the descendants of immigrants without relegating them to possessing only their parents' resources or binding them to institutional conditions. Instead, I recognize how they develop certain forms and volumes of capital throughout their education and labour market trajectories. 


\subsubsection{Gendered Transitions}

Gender plays out in different ways through the social trajectories of young people. Gendered forms of capital possessed or developed by mothers and fathers of the respondents is one way in which gendered transitions could be understood. Bourdieu helps elucidate how social class functions and changes at the micro-level of transition. However, this approach is less applicable for my analysis of gender and gendered capitals in social trajectories. Feminist scholars have criticised Bourdieu's writings, commonly taking issue with his depiction of women as bearers rather than producers of capital and his tendency to ignore the role of gender in the acquisition of resources (Adkins 2003; Skeggs 2004a, b, c). McRobbie (2002) argued that Bourdieu's focus on dominated groups and their suffering in The Weight of the World was an elaborate empirical description of their condition rather than a theoretical explication of their reproduction or mobility patterns. Skeggs (2004c) blamed Bourdieu's entrapment in the "dominant symbolic", which is defined and dominated by middle-class values. Researchers have also documented specifically gendered forms of capital. Skeggs (2004a, b) uncovered different forms of gendered capital and values among working-class women, including loyalty and caring. Reay (2004) identified "emotional capital" among mothers and its significance for their children's educational attainment. Hence gendered capitals such as emotional capital will be analysed in the book.

Alongside gendered forms of capital, gender roles, norms and values underpin young people's transition trajectories and affect their education, occupations and matrimonial strategies (McDowell 2009; Gaskell 1992). Gender shapes young people's educational and occupational choices and decisions. During the post-war manufacturing industry boom, gender roles seemed to have had a major influence on transition pathways: men became the breadwinners, working outside the home, and women stayed inside, doing work for their own household. However, this pattern applied mostly to middle-class families where the husbands were able to provide financially for the family. Working-class women have always had to make a living while also bearing the responsibility for household tasks. Clearly, circumstances have changed over the last half century, especially with women's mass entry into education and the labour market. However, these developments led to women being active both in the labour market and at home, where they remain the main caregiver (Hochschild 1989). Such changes are reflected not only in objectively observable trends, but also in young people's subjective orientations, which, in turn, determine their school-to-work pathways. Weis (1990) noted that young women are increasingly motivated to pursue higher education and enter the labour market rather than to become 'mere' homemakers. However, Lehmann's (2007) study showed that while young women were aspiring to higher education and employment, they were motivated in part by their future domestic roles and/or anticipated mothering duties. Talking about their transitions, the young women expressed concern about how to juggle being a mother and a businesswoman, while the young men raised no concerns about marriage or parenting (Lehmann 2007). For other young women, who could not get a foothold in education or the labour market, becoming mothers, pursuing domestic roles and taking up part-time employment 
remained valid transition pathways (Wallace 1987) and this tendency was still evident two decades later (Bynner 2001). Gendered values also pressured young men into certain orientations or options. Bynner (2005) saw how gendered norms forced young men from lower social classes into the labour market earlier. This shows how gender, social class and age intersect to shape transition trajectories. What is considered to be an acceptable transition pathway or an acceptable age to make a certain transition, varies across social classes and is sharply coloured by gender.

Gender not only intersects with social class but also with ethnicity in shaping the transition pathways since ethnic communities' gendered norms and values have a significant effect on young people's motivations, aspirations and social trajectories. A recent study by Hushek (2011) showed that descendants of Turkish immigrants had distinctly different union formation patterns compared to peers with native-born parents: they wedded earlier and usually married a partner from Turkey. Women also married earlier than men. This finding has raised several questions about their youth transitions. What are acceptable and desirable marrying ages for descendants of Turkish immigrants within their ethnic community? How do they vary between men and women? What kind of gendered norms shape their transitions concerning marriage, among other decisions? This book therefore analyzes gendered transitions not only in terms of gendered forms of capital, but also with regard to the intersections of gender, ethnicity, social class and age in shaping the transition trajectories of men and women.

\subsubsection{The Role of Ethnicity}

While previous youth transition studies have documented, though not explicated, the various transition pathways among ethnic minority youth, this book seeks to fill this gap. However, to do that without reifying a group or overgeneralizing certain characteristics (Brubaker 1992, 2004), I needed to first of all recall that the Turkish community I was analyzing encompasses immigrants and their descendants from multiple generations. It should not, therefore, be seen as a homogenous whole: like all ethnic communities, it is a heterogeneous group. This heterogeneity is visible along the lines of social class, gender and generation; the time of, and age at, arrival also affect migrants' life chances in a host country. Waters and Jimenez (2005) illustrated how on-going flows of Mexican migration could lead to the same ethnic community having multiple generations of migrants and their descendants on their own pathways, each moving at their own pace. An immigrant parent who entered the host setting at the age of 30 will acquire different forms of capital than a fellow immigrant parent who arrived as an adolescent: the latter has had more opportunities to learn the local language and enrol in educational institutions, even if for a minor vocational degree. Or, unlike an immigrant parent who might have fallen into unemployment or had to go on sick leave, a migrant parent who has been active on the labour market or established a business will have developed various forms of capital over time, shaping the resources available to them and their offspring. 
Ethnic groups, moreover, are not static entities. They change and develop according to the forms of capital they have brought along with them, as well as in response to the structural conditions within their host country. Early studies described Turkish communities in the Netherlands as low-educated migrants working in low-skilled jobs with the primary goal of saving money and returning to Turkey within a short span of time. Lindo (2000) found that the group had little interest in providing for their children's education; instead they wanted them to work and contribute to family savings. Around the same time, Coenen (2001) showed that there were also Turkish immigrant parents who were trying to encourage their children not to follow their example and to break the circle of disadvantage. Later studies of the same community revealed that as return migration plans faded, expectations for their children's lives shifted (Crul 2013) and the migrants become more supportive of their children's education. Another factor was the disappearance of low-skilled jobs in the host countries' manufacturing industries that had previously provided work for migrants and their descendants: migrants subsequently realized that the only way for their children to access jobs was via the education system.

Ethnicity therefore played a dramatic role in creating the conditions, both subjective and objective, in which descendants of Turkish immigrants found themselves. Moreover, there were differences in the group's norms and values. Explicating this variation, as I do in this book, is key to understanding its effect on young people.

\subsection{Case Selection and Methodology}

Several parameters informed my case selection. The Netherlands and France were fitting choices because each setting had its own unique conditions for youth transitions. Though I focus on a city-to-city micro-level comparison between Amsterdam and Strasbourg, some of the most significant structural differences affecting youth transitions are found at the national macro-level (Devadason 2008). This is especially salient for education systems, which are centralized in both countries (Kerckhoff 1995). My case selection was thus primarily based on the different ways in which the Dutch and the French education systems prepare young people for the labour market. For the descendants of immigrants with no contacts or networks to tap into for career opportunities, education provides the most promising channel for building certain forms of capital.

The Dutch education system is marked by early stratification as pupils are streamed into educational tracks at the age of 12 . The French system is more comprehensive, with tracking occurring at the end of lower-secondary education when students are 15. These stratification processes set the conditions for youth transitions, and are crucial in determining which pathways young people can follow into higher education and the labour market (Bol and Van De Werfhorst 2013). The nature of tracking also points to the retrospective nature of youth transition; rather than happening at one point in time, it is a process that begins at an early age. This book therefore analyses the very experience of tracking. I examine how much space 
educational institutions give parents and analyze the extent to which they are able to influence the tracking process with the forms of capital available to them. Observing differences in schooling sheds light on the unique conditions of prolonged youth transitions since the Dutch and French education systems each have their own routes to higher education (see Chap. 2).

Another major difference between the settings manifests in how school-learned skills are rewarded in the labour market. The Dutch education system offers vocational training at school along with extended internships. The skills acquired through training at school and in internships reflect employer and labour market expectations, thus smoothing access to the labour market (Iannelli and Raffe 2007). In France, school-based vocational education incorporates relatively meagre employment experience and internship; the alternative is an apprenticeship programme, which is less prestigious and thus less popular among young people. Maurice and his colleagues (1986) characterized the French labour market as an "occupational space" wherein skills are gained through on-the-job training, not earlier at school or through internships. As a result, vocational graduates may experience more difficulties finding jobs in France. This book accordingly juxtaposes the differential experiences of vocational and academic track students across the two settings. In so doing, it examines the extent to which institutional settings foster prolonged and complex transitions (see Chap. 4).

Amsterdam and Strasbourg differ with respect to their labour market structures and the impact of macro-economic trends. Over the last decade-and particularly from 2008 to 2009, the year after the global financial crisis hit and the period in which my research was conducted - the Dutch economy was in better shape than that of France. At the time of my research, Strasbourg - the capital of Alsace, one of France's most economically vibrant regions-had relatively low youth unemployment (16\%), though it was still higher than Amsterdam's rate (7\%). Amsterdam's economy is dominated by the service sector, though its financial sector is growing, and healthcare, ICT and knowledge are also major sectors. While Strasbourg has a strong service sector, the Alsace region has also retained a relatively strong traditional manufacturing industry. Factories are a major source of employment in the region, and there are indications that they may be significant in creating employment for descendants of immigrants (Morel-Chevillet 2005).

Comparing these two cities - one classified as a strong service economy and the other as a declining industrial economy increasingly dependent on servicesenabled me to explore whether the persistence of industrial forms of employment influenced youth transitions. For instance, one might hypothesize that young people in Strasbourg, especially those anticipating working in industry, might be expected to pursue more traditional transitions than those in Amsterdam. The Dutch capital's robust service economy also influences the employment market, which provides more abundant opportunities for those leaving, or about to leave, the education system.

The second major reason for my case selection was the presence of a substantial group of Turkish immigrants and their descendants in both cities. In view of this, a brief history of Turkish migration to both countries is useful. After Turkey signed its first bilateral labour recruitment agreement with Germany in 1961, the Netherlands 
signed a similar agreement in 1964 and France followed in 1965. Migration to the Netherlands began on a small scale, but accelerated in the following years (Abadan Unat 2006; Akgündüz 2008). During the recruitment period from 1964 to 1974 up to 30,000 Turks migrated to the Netherlands (Dagevos et al. 2006). Most came from central and eastern Anatolia (Akgündüz 2008). Even though the Netherlands terminated the recruitment agreements in 1974, Turkish migration continued through unofficial channels and family reunification. The largest share of family reunifications took place in the 1980s, when the Netherlands' Turkish population almost doubled. Since the mid-1990s, Turkish immigration to the Netherlands has remained relatively low and stable, with an estimated 4000-5000 young Turks emigrating annually; some to study or work, though mostly for marriage (Nicolaas et al. 2010). Official statistics (CBS 2012) document the Turkish community in the Netherlands as consisting of 388,967 people, $51 \%$ of whom were born in the Netherlands and $49 \%$ of whom were born in Turkey (ibid).

By 1969, France was receiving high numbers of immigrants from Turkey. It cancelled its labour agreement with Turkey in 1974 (the same year as the Netherlands) (Danış and İttİş 2008). According to Turkish employment agency statistics, approximately 55,000 workers emigrated to France between 1965 and 1974 (Akgündüz 2008). However, this number excludes those who entered France via Germany and those who moved along unofficial routes and become legalized at a later date. It is noteworthy that Turkey's initial labour migration flow to France was larger than to the Netherlands. Furthermore, despite 1974s termination of labour agreements, Turkish migration to France persisted through private employers, family reunification and illegal entry. In 1999, official statistics counted 208,000 people of Turkish origin in France (Simon 2003). As French censuses do not collect information on immigrants' descendants born within the country, this statistic only reflects members of the Turkish community born outside of France. Official numbers are unavailable, though Nielsen et al. (2014) estimated France's population to include 500,000 people of Turkish origin.

In the Netherlands, most immigrants from Turkey settled in large cities, such as Rotterdam and Amsterdam (Bocker 2000). Like most guest workers, the majority of Turks were employed in low-skilled manufacturing jobs. In Amsterdam, most were employed in factories, such as Ford or ADM (Rath 2002). Over time, economic conditions caused the closure of these plants and the workers decamped to other industries. Self-employed entrepreneurship also grew among Turkish immigrants. In Amsterdam, Turks formed the largest group of ethnic entrepreneurs during the 1990s, working in catering, retail, wholesale and manufacturing (ibid). Turks were the only immigrant group active in manufacturing industries; in the late 1980s and early 1990s, the garment industry in Amsterdam was largely run by Turkish entrepreneurs relying on co-ethnic workers and using informal employment practices, which were tolerated by the Dutch authorities as they stimulated economic growth (Raes et al. 2002). However, these enterprises were undercut by producers in Eastern Europe and Turkey and they faced further difficulties when the Dutch government imposed tighter labour regulations (ibid), leading to most of the businesses being shuttered. Today, Turkish immigrants and their descendants are active as 
entrepreneurs in the catering and retail industries. However, since the 1990s, inactivity rates have risen among members of the first generation who have become unemployed or officially disabled (CBS 2004).

Turkish guest workers originally came to France to work in its manufacturing industries (Petek-Salom 2002). After the 1973-1974 oil crisis, unemployment started to rise among this group. During the 1990s, the unemployment rate among Turks in France reached 29\% (Simon 2003). While some Turks successfully transitioned to the service economy (notably in construction and catering), the majority remained in labour-intensive industrial establishments (Hargreaves 1995, 2007). According to the 1999 records of the National Institute of Statistics and Economic Studies (INSEE), 64\% of Turks in France were employed as manual workers and only $8 \%$ were self-employed entrepreneurs (Simon 2003). By 2004, the number of Turkish manual workers had fallen to $58 \%$, while those in other jobs rose to $15 \%$ and the self-employed to 9\% (Perrin-Haynes 2008). Turkish immigrants and their descendants have dispersed throughout the country, though they are concentrated in Paris and the regions of Rhone-Alpes and Alsace (Danış and İrtİş 2008). In Alsace, of which Strasbourg is the capital, Turks have mostly held large-scale manufacturing jobs and worked in mining. Almost $80 \%$ of Turkish men in this region work in industry and construction, while Turkish women tend to cluster more in the service and administrative sectors (Morel-Chevillet 2005). Unemployment is a serious problem in France's Turkish community, whose members are three times as likely to be unemployed as peers of European origin (Perrin-Haynes 2008). The situation is most striking among Turkish women, who form the largest group of inactive females among all immigrant and non-immigrant groups in France (ibid).

Turks have comparable populations in the Netherlands and France, but France's larger overall population and the presence of other colonial minorities renders Turkish immigrants less visible. Strasbourg is an exception. This city is home to a Turkish population of considerable size that is even more visible than immigrants from the Maghreb, from which the majority of immigrant communities in France's other major cities originate (Kirszbaum et al. 2009). The Alsace region as a whole has almost 30,000 Turkish immigrants and their descendants (Morel-Chevillet 2005). In Amsterdam, the Turkish population is close to 40,000 (O+S 2012). Most immigrants to both cities were part of the guest worker flows: consequently, the young people I studied are almost exclusively the descendants of guest workers (Bocker 2000; Danış and İrtİş 2008). In both cities, the majority of Turkish immigrants and their descendants live in large suburban districts with social housing. In Amsterdam, the majority live in the west and east, many in social housing complexes (Musterd and Van Kempen 2009). In Strasbourg, the majority are concentrated with other immigrant groups in quartiers such as Mulhouse or Hautepierre (Brabant 1989).

For my case selection, I relied on a descriptive analysis of The Integration of the European Second Generation (TIES) Survey, the first international comparative study on the children of Turkish, Moroccan and ex-Yugoslavian immigrants living in 15 European cities across eight countries (Crul and Heering 2008). Collecting data between 2007 and 2009, the survey set out to compare how "integration contexts" affect the trajectories of immigrants' children and to assess the extent to which they achieve parity with their peers with native-born parents (Crul et al. 
2012). The survey provided detailed retrospective information on educational trajectories, school-to-work transitions and labour market activity. It also documented household composition, parental background, neighbourhood configuration, citizenship status and identity, among other details. I made extensive use of TIES survey data for all the empirical studies within this book, and for background information on Amsterdam, Rotterdam, Strasbourg and Paris. TIES respondents were asked for detailed information about their parents' migration, educational and occupational backgrounds. A preliminary analysis of TIES survey results showed that Strasbourg was a good match with Amsterdam, since the Turkish families in these cities described similar migration histories and educational backgrounds, while respondents in Paris came more from highly educated backgrounds or arrived seeking political asylum. Both cities had a high proportion of migrants from central Anatolia, with $62 \%$ of Turks in Amsterdam and $43 \%$ of Turks in Strasbourg having their origins there. Regions of origin identified in the TIES survey seemed to be consistent with overall migration patterns to the Netherlands and France, with the majority of migrants hailing from central Anatolia (Akgündüz 2008). Despite high missing values, in each city a small group of parents, who had arrived in the host country before the age of 15, were reported. In Amsterdam, this group comprised $5.5 \%$ of the fathers and $7 \%$ of the mothers, while in Strasbourg it comprised $2.4 \%$ of the fathers and $5 \%$ of the mothers. As they had arrived during adolescence, this group could be classified as the " 1.5 generation". The TIES survey shows that mothers had lower education levels than fathers in both cities: $13.5 \%$ of the mothers in Amsterdam and $\mathbf{1 7 . 9 \%}$ in Strasbourg had never had any schooling or had only attended religious school, compared to only $5.9 \%$ of the fathers in Amsterdam and $2.8 \%$ in Strasbourg who had had no schooling at all, while over $40 \%$ had attended primary school and $20 \%$ had attended secondary school. The relatively high presence of 1.5 generation mothers meant that more mothers than fathers had received some sort of schooling in the host countries: $7.6 \%$ in Amsterdam and $6.8 \%$ in Strasbourg said they had taken courses, ranging in level from primary to higher education. Parents in Amsterdam were less active in the labour market, with $32.4 \%$ of the respondents' fathers and $18.9 \%$ of their mothers being active, compared to $48 \%$ of the fathers and $27 \%$ of the mothers in Strasbourg. We observed that parents in Amsterdam were slightly older than the parents in Strasbourg who were mostly in their 40s. In Amsterdam, economically active parents mostly worked in the service sector, while in Strasbourg they (mostly fathers) were concentrated in construction, followed by manufacturing.

These descriptive trends from the TIES survey illustrate comparable migration histories, age groups and education levels for parents in both cities, although the parents in Strasbourg are slightly younger and more active on the labour market. Tracking these similarities and differences is crucial as it illustrates how immigrants and their descendants fared in different institutional settings and the differences that may be important when considering the role that parents play in youth transitions. To reiterate, parents who arrived in a host country at an earlier age or who are active on the labour market are more likely to have acquired forms of capital crucial to transitions, particularly in light of institutional structures and the specific opportunities that they offer or restrict. 


\subsection{Data Collection and Research Techniques}

Throughout my research, I applied a mixed methodological approach, using both quantitative and qualitative methods (Creswell 2003; Niglas 2009). This choice was motivated first by the need to track broad patterns of transitions across two settings, for which I applied quantitative analysis. Second, I wanted to detail my respondents' social trajectories within such transition patterns, for which I applied indepth qualitative methods. During the exploratory and analysis phases, the quantitative and qualitative data informed, supplemented and strengthened one other. Each of this book's chapters reflects the mixed-method design, structured to report the results of quantitative and qualitative methods in a mutually complementary way.

\subsubsection{Quantitative Data: The TIES Survey, Sampling and Research Design}

The quantitative data came from the TIES survey which, in order to collect representative data from the descendants of immigrants in the selected cities, adopted adequate appropriate sampling strategies. In Amsterdam the survey accessed up-todate population registers for information on the age, sex, date of birth and birth place of respondents, as well as their parents' place of birth. This information was readily available in the municipal population register (GBA), which provided the most accurate information available on the parents (Groenewold and LessardPhillips 2012). In Amsterdam, the descendants of immigrants from Turkey and the comparison group were sampled from the same neighbourhoods. The target group was aged 18-35, and a total of 237 native-born descendants of Turkish immigrants, 242 native-born descendants of Moroccan immigrants and 259 respondents from the comparison group (of Dutch ethnicity) participated in the survey. The response rate was $29.9 \%$ for the descendants of Turkish immigrants and $40.1 \%$ for the control group. Groenweld and his colleagues in NIDI (Nederlands Interdisciplinair Demografisch Instituut) examined selection bias using the personal records of the municipal registry and concluded that the non-response bias was slight with regard to the characteristics being compared (Groenewold 2008). In France, the sampling process proved more difficult as the information needed to identify the respondents was missing from the population register since the municipalities did not register parents' country of birth (Groenewold and Lessard-Phillips 2012). The French team at INED (Institut National d'Etudes Démographiques) developed an alternative strategy constructing a frame of the names and addresses of descendants of immigrants by using phone books in Paris and Strasbourg (Milewski and Hamel 2010). Applying onomastic identification procedures, they identified 2745 people in Strasbourg as having Turkish family names, who were then organized according to postcode. These postal code areas were then classified according to the proportion 
of registered residents with Turkish names. A screening was then conducted using questionnaires to recruit eligible respondents. The questionnaire included basic information such as age, sex, individual and parents' country of birth to ensure that potential respondents met the criteria of the survey targets. If not, they were asked whether they had a family member living in the household who would fit the criteria as a native-born descendant of Turkish immigrants. The comparison group was selected using a similar technique. After this lengthy sampling process, a total of 252 interviews with descendants of immigrants from Turkey and 177 interviews with the comparison group were conducted. In the first stage, the response rate was $25 \%$ for the descendants of Turkish immigrants and $37 \%$ for the comparison group. One issue with regard to the sampling frame in France was the potential bias inherent in selecting "Turkish sounding names". It was argued that this strategy would miss young women who might have married a French partner or who had French fathers. However, considering the low rate of mixed marriage among Turkish immigrants and their descendants in France (Milewski and Hamel 2010), this was not considered to undermine the integrity of the sampling procedure. As an additional precaution against this, in the first stage of screening, the French team inquired whether the respondents had any female family members who had married a nonTurkish person and left the household, and, if there were, this person was included in the sample (Milewski and Hamel 2010).

In both settings, the survey questionnares were filled in face-to-a-face with the respondents. The potential language barrier was dealt with using bilingual interviewers (Groenewold and Lessard-Phillips 2012). In the Netherlands, the fieldwork began in 2006 and lasted nearly 14 months (Groenewold 2008). In France, the first round of fieldwork was conducted in 2007, and, when both rounds are considered, the fieldwork took five-and-a-half months in total (Schnell 2012). The TIES survey collected an invaluable body of data despite the difficulties with regard to sampling and data collection. Recent publications using the TIES Survey provide further detailed information on the methodology (Crul and Heering 2008; Crul et al. 2012; Huschek 2011; Schnell 2012) (Table 1.1).

The TIES survey provides detailed retrospective information about all of the respondents' school careers. This data was invaluable in helping reconstruct the educational trajectories analyzed in Chap. 2. The respondents' employment experiences are also well documented in TIES. It provides detailed information about young people's current or last job, including its duration, the type of contract, promotions as well as the number of jobs respondents have held and the duration of any periods of unemployment. Subjective questions gauged career satisfaction as well as future plans. A brief section on the school-to-work transition recorded the number of months respondents took to find their first job after leaving school and what activities they undertook during this period. The respondents' initial and later labour market activities were analyzed to yield data that could be translated into typologies that traced different transitions, how they developed over time after leaving education and whether respondents pursued active or inactive, stable or shifting pathways (see Chap. 5) (Table 1.2). 
Table 1.1 Respondents' mean age and gender, by city

\begin{tabular}{l|l|l|l|l|l|l|l|l}
\hline & \multicolumn{9}{|l|}{ Amsterdam } & \multicolumn{2}{l}{ Strasbourg } \\
\cline { 2 - 10 } & $\begin{array}{l}\text { Descendants of } \\
\text { immigrants from } \\
\text { Turkey }\end{array}$ & \multicolumn{2}{l|l}{$\begin{array}{l}\text { Descendants of } \\
\text { immigrants from } \\
\text { Turkey }\end{array}$} & \multicolumn{2}{l}{ Comparison group } \\
\cline { 2 - 10 } & Male & Female & Male & Female & Male & Female & Male & Female \\
\hline$\%$ & $46 \%$ & $54 \%$ & $48 \%$ & $52 \%$ & $38.5 \%$ & $61.5 \%$ & $45.8 \%$ & $54.2 \%$ \\
\hline $\begin{array}{l}\text { Mean } \\
\text { age }\end{array}$ & 24.6 & 24.4 & 27.6 & 27.5 & 24.3 & 24.6 & 25.4 & 26.7 \\
\hline St. dev. & 4.5 & 4.1 & 4.5 & 4.5 & 4.6 & 4.8 & 5.3 & 5.3 \\
\hline N & 109 & 128 & 123 & 136 & 97 & 155 & 81 & 96 \\
\hline
\end{tabular}

Source: TIES Survey 2008

Table 1.2 Activity at the time of the TIES survey, in percentages and $\mathrm{N}$

\begin{tabular}{|c|c|c|c|c|c|c|c|c|}
\hline & \multicolumn{4}{|c|}{ Amsterdam } & \multicolumn{4}{|c|}{ Strasbourg } \\
\hline & \multicolumn{2}{|c|}{$\begin{array}{l}\text { Descendants of } \\
\text { immigrants from } \\
\text { Turkey }\end{array}$} & \multicolumn{2}{|c|}{$\begin{array}{l}\text { Comparison } \\
\text { group }\end{array}$} & \multicolumn{2}{|c|}{$\begin{array}{l}\text { Descendants of } \\
\text { immigrants from } \\
\text { Turkey }\end{array}$} & \multicolumn{2}{|c|}{$\begin{array}{l}\text { Comparison } \\
\text { group }\end{array}$} \\
\hline & $\mathrm{N}$ & $\%$ & $\mathrm{~N}$ & $\%$ & $\mathrm{~N}$ & $\%$ & $\mathrm{~N}$ & $\%$ \\
\hline Still in school & 88 & $37 \%$ & 76 & $29 \%$ & 76 & $30 \%$ & 61 & $34 \%$ \\
\hline Working & 90 & $38 \%$ & 167 & $65 \%$ & 119 & $47 \%$ & 89 & $50 \%$ \\
\hline Unemployed & 25 & $10 \%$ & 5 & $2 \%$ & 31 & $12 \%$ & 21 & $12 \%$ \\
\hline $\begin{array}{l}\text { Inactive (sick/caring } \\
\text { for children and not } \\
\text { seeking work) }\end{array}$ & 34 & $15 \%$ & 11 & $4 \%$ & 26 & $10 \%$ & 6 & $3 \%$ \\
\hline Total (N) & 237 & $100 \%$ & 259 & $100 \%$ & 252 & $100 \%$ & 177 & $100 \%$ \\
\hline
\end{tabular}

Source: TIES Survey 2008

\subsubsection{Qualitative Fieldwork: In-depth Interviews in Amsterdam and Strasbourg}

The next step was to conduct qualitative fieldwork. The individuals I included in my qualitative study were drawn from the TIES survey respondents. The majority of TIES respondents had agreed to be approached once more. For my study, I did a total of 50 interviewees, 25 in each city. I conducted biographical interviews at their homes and workplaces, aiming to fully grasp their transition realities. I also interviewed family members, spouses whenever I was given permission.

I limited my sample to those between 20 and 30 years old at the time of interviewing so as to capture a cohort that was transitioning within common social and economic milieus. I also pursued a purposeful sampling strategy and sought a comparable distribution in terms of educational attainments, interviewing those with both academic and vocational training. My age range included people near the end of their studies, in higher education or vocational training, and those already out of school. In the latter group, I interviewed unemployed, economically active and inactive respondents. The sample variance showcased a multiplicity of transition experiences 
for an age cohort of 20-30. Although some of the respondents had found a sense of stability, none of them could be described as being in the final stage of their transitions as their careers were clearly open for further development. As a result, the design of the qualitative inquiry also aimed to capture transition as a process rather than an outcome. Over the course of 2 years, I made two field visits to each city. During my second fieldwork visit, I re-contacted the majority of respondents from the first round to see how their transitions had evolved over the year. I was able to reconnect with six respondents in Amsterdam and five in Strasbourg. The second round of interviews produced interesting results, underlining the longitudinal and on-going nature of transitions. The interviews were mainly conducted in Turkish, though I left it up to interviewees to decide the language we used. The fact that I could speak Turkish, Dutch and French, seemed to make it more appealing for most respondents to speak to me in their mother tongue. Yet during the interviews, respondents constantly switched between two languages. All the interviews were transcribed and analysed using ATLAS.ti software. Although I attempted to do a detailed coding of the dataset, my analysis ultimately relied more on the family of codes, or on a conceptual organization of the transcripts, since detailed coding tended to decontextualize the quotations, thus interrupting the flow of the interview.

In-depth interviews remain one of the most common forms of qualitative data collection, yet perspectives differ concerning what the data can legitimately offer (Ritchie and Lewis 2003). I side with the claim that the researcher 'travels' - to borrow Kvale's (1996) word-with the interviewees as they construct their stories. Probing by the interviewer provokes self-reflection on the part of the interviewee, in an effort to go more deeply into their experiences. Bourdieu (2000) warned against the 'biographical illusion', especially when an interview environment might force interviewees to put their lives in perspective and present them in organized sequences. Nevertheless, taking a biographical approach to in-depth interviews encourages respondents to reflect on their earlier experiences, and remains an essential method for collecting retrospective qualitative data. In my interviews I asked respondents to walk me through their experiences in and out of school, tell stories about their parents and describe how they saw their parents' role in their education. These in-depth biographical interviews enabled respondents to consider and articulate their own transitions. In fact, they were doing exactly what the descendant of a Turkish immigrant, back in 1980, had told Gündüz Vassaf still needed to be done: getting their voices heard.

\section{References}

Abadan-Unat, N. (2006). Bitmeyen Göç Konuk Iş̧̧̧ilikten Ulus Otesi Yurttaşlığa (2nd ed.). Istanbul: İstanbul Bilgi Üniversitesi Yayınları.

Adkins, L. (2003). Reflexivity: Freedom or habit of gender? Theory, Culture and Society, 20, $21-42$.

Akgündüz, A. (2008). Labour migration from Turkey to Western Europe, 1960-1974: A multidisciplinary analysis. Aldershot/Burlington: Ashgate Publishing Company. 
Arnett, J. J., \& Tanner, J. L. (Eds.). (2006). Emerging adults in America: Coming of age in the 21st century. Washington, DC: American Psychological Association.

Beck, U. (1992). Risk society: Towards a new modernity. London/New York: Sage.

Beck, U. (2007). Beyond class and nation: Reframing social inequalities in a globalizing world. The British Journal of Sociology, 58, 679-705.

Bennett, T., Savage, M., Silva, E. B., Warde, A., Gayo-Cal, M., \& Wright, D. (2009). Culture, class, distinction. London: Routledge.

Bocker, A. (2000). Paving the way to a better future. Turks in the Netherlands. In H. Vermeulen \& R. Penninx (Eds.), Immigrant integration. The Dutch case (pp. 153-177). Amsterdam: Het Spinhuis.

Bol, T., \& Van de Werfhorst, H. G. (2013). Educational systems and the trade-off between labor market allocation and equality of educational opportunity. Comparative Education Review, 57(2), 285-308.

Bourdieu, P. (1984). Distinction: A social critique of the judgement of taste. Cambridge, MA: Harvard University Press.

Bourdieu, P. (1985a). The forms of capital. In J. G. Richardson (Ed.), Handbook of theory and research for the sociology of education (pp. 241-258). New York: Greenwood.

Bourdieu, P. (1985b). Social space and the genesis of groups. Social Science Information, 24, $195-220$.

Bourdieu, P. (1987). What makes a social class? Berkeley Journal of Sociology, 32, 1-17.

Bourdieu, P. (1999). The weight of the world: Social suffering in contemporary society. Oxford: Polity.

Bourdieu, P. (2000). The biographical illusion. In P. Du Gay, J. Evans, \& P. Redman (Eds.), Identity: A reader (pp. 299-305). London: Sage.

Bourdieu, P. (2005). The political field, the social science field, and the journalistic field. In R. Benson \& E. Neveu (Eds.), Bourdieu and the journalistic Field (pp. 29-47). Cambridge: Polity Press.

Brabant, J. (1989). Turcs Et Algeriens En Alsace Moyenne: Une Difficile Insertion. Annales De Geographie, 1989. Societe De Geographie, 98, 333-336.

Bradley, H., \& Devadason, R. (2008). Fractured transitions: Young adults' pathways into contemporary labour markets. Sociology, 42(1), 119-136.

Brinbaum, Y., \& Kieffer, A. (2009). Trajectories of immigrants' children in secondary education in France: Differentiation and polarization. Population, 64(3), 507-554.

Brubaker, R. (1992). Citizenship and nationhood in France and Germany. Cambridge: Harvard University Press.

Brubaker, R. (2004). Ethnicity without groups. Cambridge: Harvard University Press.

Bynner, J. (2001). British youth transitions in comparative perspective. Journal of Youth Studies, 4, 5-23.

Bynner, J. (2005). Reconstructing the youth phase of the life course: The case of emerging adulthood. Journal of Youth Studies, 8, 367-384.

Caglar, A. S. (1998). Popular culture, marginality and institutional incorporation: German-Turkish rap and Turkish pop in Berlin. Cultural Dynamics, 10(3), 243-261.

CBS. (2004). Allochtonen in Nederland En Leefsituatie. Den Haag: CBS[Host].

CBS. (2012). Turkse Ingezetenen in Nederland 2011. Den Haag: Centraal Bureau Voor Statistics.

Çelik, Ç. (2015). 'Having a German passport will not make me German': Reactive ethnicity and oppositional identity among disadvantaged male Turkish second-generation youth in Germany. Ethnic and Racial Studies, 38(9), 1646-1662.

Coenen, L. (2001). Word niet zoals wij: de veranderende betekenis van onderwijs bij turkse gezinnen in Nederland. Amsterdam: Het Spinhuis.

Côté, J. E. (2014a). Towards a new political economy of youth. Journal of Youth Studies, 17(4), $527-543$.

Côté, J. E. (2014b). Youth studies: Fundamental issues and debates. Houndmills: Palgrave Macmillan.

Côté, J., \& Bynner, J. M. (2008). Changes in the transition to adulthood in the UK and Canada: The role of structure and agency in emerging adulthood. Journal of Youth Studies, 11(3), 251-268. 
Creswell, J. W. (2003). Research design: Qualitative, quantitative, and mixed methods approaches. London: Sage.

Crompton, R. (2010). Class and employment. Work, Employment \& Society, 24(1), 9-26.

Crul, M. (2013). Snakes and ladders in educational systems; access to higher education for secondgeneration Turks in Europe. Journal of Migration and Ethnic Studies, 39(9), 1383-1401.

Crul, M., \& Heering, L. (2008). The position of the Turkish and Moroccan second generation in Amsterdam and Rotterdam. The ties study in the Netherlands. Amsterdam: Imiscoe.

Crul, M., \& Mollenkopf, J. (Eds.). (2012). The changing face of world cities: Young adult children of immigrants in Europe and the United States. New York: Russell Sage Foundation.

Crul, M., \& Schneider, J. (2010). Comparative integration context theory: Participation and belonging in new diverse European cities. Ethnic and Racial Studies, 33(7), 1249-1268.

Crul, M., \& Vermeulen, H. (2003). The second generation in Europe. International Migration Review, 37(4), 765-986.

Crul, M., Schneider, J., \& Lelie, F. (2012). The European second generation compared: Does the integration context matter? Amsterdam: Amsterdam University Press.

Crul, M., Keskiner, E., \& Lelie, F. (2017). The upcoming new elite among children of immigrants: A cross-country and cross-sector comparison. Ethnic and Racial Studies, 40(2), 209-229. https://doi.org/10.1080/01419870.2017.1245432.

Dagevos, J., Euwals, R., Gijsberts, M., \& Roodenburg, H. (2006). Turken in Nederland en Duitsland. De Arbeidsmarktpositie Vergeleken. Den Haag: Sociaal En Cultureel Planbureau.

Danış, D., \& İrtiş, V. (2008). Entegrasyonun Ötesinde Türkiye’den Fransa'ya Göç Ve Göçmenlik Halleri. İstanbul: İstanbul Bilgi Üniversitesi Yayınları.

Devadason, R. (2008). To plan or not to plan? Young adult future orientations in two European cities. Sociology, 42(6), 1127-1145.

Du Bois-Reymond, M. (1998). "I Don't want to commit myself yet": Young people's life concepts. Journal of Youth Studies, 1(1), 63-79.

Du Bois-Reymond, M. (2009a). Integrated transition policies for European young adults: Contradictions and solutions. In I. Schoon \& R. K. Silbereisen (Eds.), Transitions from school to work: Globalization, individualization, and patterns of diversity (pp. 331-352). New York: Cambridge University Press.

Du Bois-Reymond, M. (2009b). Models of navigation and life management. In A. Furlong (Ed.), Handbook of youth and young adulthood new perspectives and agendas (pp. 47-54). Oxon: Routledge.

Erel, U. (2010). Migrating cultural capital: Bourdieu in migration studies. Sociology, 44(4), 642-660.

Evans, K. (2002). Taking control of their lives? Agency in young adult transitions in England and the new Germany. Journal of Youth Studies, 5(3), 245-269.

Evans, K., \& Furlong, A. (1996). Metaphors of youth transition: Niches, pathway, trajectories or navigations. In J. Bynner, L. Chisholm, \& A. Furlong (Eds.), Youth, citizenship and social change in a European context. Ashgate: Aldershot, Hants.

Friedman, S. (2016). Habitus clivé and the emotional imprint of social mobility. The Sociological Review, 64(1), 129-147.

Furlong, A. (1998). Youth and social class: Change and continuity. British Journal of Sociology of Education, 19(4), 591-597.

Furlong, A. (2009). Handbook of youth and young adulthood. New perspectives and agendas. London: Routledge.

Furlong, A., \& Cartmel, F. (1997). Young people and social change individualization and risk in late modernity. Buckingham: Open University Press.

Gaskell, J. (1992). Gender matters from school to work. Toronto: Oise Press.

Giddens, A. (1991). Modernity and self-identity: Self and society in the late modern age. Stanford: Stanford University Press.

Gracia, P., Vázquez-Quesada, L., \& Van de Werfhorst, H. G. (2016). Ethnic penalties? The role of human capital and social origins in labour market outcomes of second-generation Moroccans and Turks in the Netherlands. Journal of Ethnic and Migration Studies, 42(1), 69-87. 
Groenewold, G. (2008). Sample design, survey implementation and evaluation. In M. Crul \& L. Heering (Eds.), The position of the Turkish and Moroccan second generation in Amsterdam and Rotterdam. The ties study in the Netherlands (pp. 105-124). Amsterdam: Imiscoe.

Groenewold, G., \& Lessard-Phillips, L. (2012). Research methodology. In M. Crul, J. Schneider, \& F. Lelie (Eds.), The European second generation compared: Does the integration context matter? (pp. 39-57). Amsterdam: Amsterdam University Press.

Hargreaves, A. G. (1995). Immigration, 'race' and ethnicity in contemporary France. Burns: Oates.

Hargreaves, A. G. (2007). Multi-ethnic France immigration, politics, culture and society. New York/London: Routledge.

Heath, A., \& Brinbaum, Y. (2007). Guest editorial: Explaining ethnic inequalities in educational attainment. Ethnicities, 7(3), 291-305.

Heath, A. F., Rothon, C., \& Kilpi, E. (2008). The second generation in Western Europe: Education, unemployment, and occupational attainment. Annual Review of Sociology, 34, 211-235.

Heinz, W. R. (2009). Youth transitions in an age of uncertainity. In A. Furlong (Ed.), Handbook of youth and young adulthood new perspectives and agendas (pp. 19-29). Oxon: Routledge.

Hochschild, A. (1989). The second shift: Working mothers and the revolution at home. New York: Viking.

Huschek, D. (2011). Union formation \& partner choice of the second generation Turkish origin in Europe. Doctoral thesis, Vrije Univeristy.

Iannelli, C., \& Raffe, D. (2007). Vocational upper-secondary education and the transition from school. European Sociological Review, 23(1), 49-63.

Jenkins, R. (2002). Pierre Bourdieu. London: Routledge.

Jones, G. (2009). From paradigm to paradox: Parental support and transitions to independence. In I. Schoon \& R. K. Silbereisen (Eds.), Transitions from school to work: Globalization, individualization, and patterns of diversity (pp. 145-164). New York: Cambridge University Press.

Kasinitz, P., Mollenkopf, J. H., Waters, M. C., \& Holdaway, J. (2008). Inheriting the city. The children of immigrants come of age. New York: Russell Sage Foundation.

Kastoryano, R. (2002). Negotiating identities: States and immigrants in France and Germany. Princeton: Princeton University Press.

Kaya, A., \& Kentel, F. (2005). Euro-Turks: A bridge or a breach between Turkey and the European Union? (No. 14). Brussels: Centre for European Policy Studies.

Kerckhoff, A. C. (1995). Institutional arrangements and stratification processes in industrial societies. Annual Review of Sociology, 21(1), 323-347.

Keskiner, E. (2015). "Is it merit or cultural capital?" the role of parents during early tracking in Amsterdam and Strasbourg among descendants of immigrants from Turkey. Comparative Migration Studies, 3(1), 9.

Keskiner, E. (2017). Student employment among descendants of Turkish migrants in Amsterdam and Strasbourg. Journal of Education and Work, 30(3), 203-216.

Keskiner, E., \& Crul, M. (2017). How to reach the top? Fields, forms of capital, and strategies in accessing leadership positions in France among descendants of migrants from Turkey. Ethnic and Racial Studies, 40(2), 283-300.

Kirszbaum, T., Brinbaum, Y., Simon, P., \& Gezer, E. (2009). The children of immigrants in France: The emergence of a second generation. Florence: UNICEF Innocenti Research Centre.

Konyali, A. (2017). International opportunities on the way up: Alternative career paths of descendants of migrants from Turkey in the field of professional business services. Ethnic and Racial Studies, 40(2), 264-282.

Kvale, S. (1996). InterViews: An introduction to qualitative research interviewing. Thousand Oaks: Sage.

Lehmann, W. (2007). Choosing to labour? School-to-work transitions and social class. Ithaca: Mcgill-Queen's University Press.

Lessard-Phillips, L., Fibbi, R., \& Wanner, P. (2012). Assesing the labour market position and its determinants for the second generation. In M. Crul, J. Schneider, \& F. Leslie (Eds.), The European second generation compared: Does the integration context matter? (Imiscoe Research Series) (pp. 165-224). Amsterdam: Amsterdam University Press. 
Levitt, P. (2009). Roots and routes: Understanding the lives of the second generation transnationally. Journal of Ethnic and Migration Studies, 35(7), 1225-1242.

Lindo, F. (2000). Does culture explain? Understanding in differences in school attainment between Iberian and Turkish youth in the Netherlands. In H. Vermeulen \& J. Perlmann (Eds.), Immigrants, schooling and social mobility (pp. 206-224). Houndmills: Macmillan Press Ltd..

Maurice, M., Sellier, F., \& Silvestre, J. J. (1986). The social foundations of industrial power: A comparison of France and Germany. Cambridge: MIT Press.

Mcdowell, L. (2009). New masculinities and femininities: Gender divisions in the new economy. In A. Furlong (Ed.), Handbook of youth and young adulthood new perspectives and agendas (pp. 58-65). London: Routledge.

McRobbie, A. (2002). A mixed bag of misfortunes? Bourdieu's weight of the world. Theory, Culture \& Society, 19(3), 129-138.

Milewski, N., \& Hamel, C. (2010). Union formation and partner choice in a transnational context: The case of descendants of Turkish immigrants in France. International Migration Review, 44(3), 615-658.

Modood, T. (2004). Capitals, ethnic identity and educational qualifications. Cultural Trends, 13(2), $87-105$.

Morel-Chevillet, R. (2005). Immigrer en Alsace. [Migration to Alsace]. Population, 30, 8-9.

Mueller, W., \& Shavit, Y. (1998). From school to work: A comparative study of educational qualifications and occupational destinations. Oxford: England University Press.

Musterd, S., \& Van Kempen, R. (2009). Segregation and housing of minority ethnic groups in Western European cities. Tijdschrift voor Economische en Sociale Geografie, 100(4), 559-566.

Nicolaas, H., Wobma, E., \& Ooijevaar, J. (2010). Demografie Van Allochtonen: Historie En Prognose/Allochtonen In Nederland 2003". Den Haag: Centraal Bureau Voor De Statistiek.

Nielsen, J., Akgönül, S., Alibašić, A., \& Racius, E. (Eds.). (2014). Yearbook of Muslims in Europe (Vol. 6). Leiden: Brill.

Niglas, K. (2009). How the novice researcher can make sense of mixed methods designs. International Journal of Multiple Research Approaches, 3, 34-46.

O+S. (2012). Amsterdamincijfers2012 [Online]. Amsterdam: Amsterdam Gemeente Bureau Onderzoek En Statistiek. Available: http://www.os.amsterdam.nl/tabel/6565/. Accessed Nov 2012.

Perrin-Haynes, J. (2008). Principal: L'activité Des Immigrés En 2007.

Petek-Salom, G. (2002). Peut-On Encore Parler De Politique De Réinsertion? Hommes Et Migrations, 1236, 53-58.

Plug, W., \& Du Bois-Reymond, M. (2006). Transition patterns between structure and agency. In A. Walther, M. D. Bois- Reymond, \& A. Biggart (Eds.), Participation in transition motivation of young adults in Europe for learning and working. Frankfurt Am Main: Peter Lang.

Raes, S., Rath, J., Dreef, M., Kumcu, A., Reil, F., \& Zorlu, A. (2002). Amsterdam: Stitched up. In J. Rath (Ed.), Unravelling the rag trade: Immigrant entrepreneurship in seven world cities. Oxford/New York: Berg/University of New York Press.

Rath, J. (2002). A quintessential immigrant niche? The non-case of immigrants in the Dutch construction industry. Entrepreneurship \& Regional Development, 14(4), 355-372.

Reay, D. (2004). Gendering Bourdieu's concepts of capitals? Emotional capital, women and social class. The Sociological Review, 52(s2), 57-74.

Rezai, S., Crul, M., Severiens, S., \& Keskiner, E. (2015). Passing the torch to a new generation: A qualitative study of the highly educated second generation's receiving of parental support and giving of support to the younger generation. Journal of Comparative Migration Studies, 3, 12.

Ritchie, J., \& Lewis, J. (2003). Qualitative research practice: A guide for social science students and researchers. London: Sage.

Savage, M., Warde, A., \& Devine, F. (2005). Capitals, assets, and resources: Some critical issues. The British Journal of Sociology, 56(1), 31-47.

Schneider, J., \& Lang, C. (2014). Social mobility, habitus and identity formation in the Turkish German second generation. New Diversities, 16(1), 89-105.

Schnell, P. (2012). Educational mobility of second-generation Turks in cross-national perspective. Doctoral thesis, University of Amsterdam. 
Schnell, P., \& Fibbi, R. (2016). Getting ahead: Educational and occupational trajectories of the 'new' second-generation in Switzerland. Journal of International Migration and Integration, 17(4), 1085-1107.

Simon, P. (2003). France and the unknown second generation: Preliminary results on social mobility. International Migration Review, 37(4), 1091-1119.

Skeggs, B. (2004a). Class, self culture. London: Routledge.

Skeggs, B. (2004b). Context and background: Pierre Bourdieu's analysis of class, gender and sexuality. The Sociological Review, 52(2_suppl), 19-33.

Skeggs, B. (2004c). Exchange, value and affect: Bourdieu and 'the self'. The Sociological Review, 52(2_suppl), 75-95.

Soysal, L. (2001). Diversity of experience, experience of diversity: Turkish migrant youth culture in Berlin. Cultural Dynamics, 13(1), 5-28.

Van De Werfhorst, H. G., \& Van Tubergen, F. (2007). Ethnicity, schooling, and merit in the Netherlands. Ethnicities, 7(3), 416-444.

Vassaf, G. (1983). Daha Sesimizi Duyuramadık: Avrupa'daki Türk IşÇi Çocukları [We still Couldn't make our voices heard: The children of Turkish workers in Europe]. Istanbul: Belge Yayinlari.

Vermeulen, F., \& Keskiner, E. (2017). Bonding or bridging? Professional network organizations of second-generation Turks in the Netherlands and France. Ethnic and Racial Studies, 40(2), 301-320.

Waldring, I., Crul, M., \& Ghorashi, H. (2015). Discrimination of second-generation professionals in leadership positions. Social Inclusion, 3(4), 38-49.

Wallace, C. (1987). For richer, for poorer. London: Tavistock.

Waters, M. C., \& Jiménez, T. R. (2005). Assessing immigrant assimilation: New empirical and theoretical challenges. Annual Review of Sociology, 31, 105-125.

Webster, C. (2009). Young people, 'race' and ethnicity. In A. Furlong (Ed.), Handbook of youth and young adulthood new perspectives and agendas (pp. 82-89). London: Routledge.

Weis, L. (1990). Working class without work: High school students in a de-industrializing economy. New York: Routledge.

Willoughby, B. J., Hall, S. S., \& Luczak, H. P. (2015). Marital paradigms: A conceptual framework for marital attitudes, values, and beliefs. Journal of Family Issues, 36(2), 188-211.

Witteveen, D., \& Alba, R. (2018). Labour market disadvantages of second-generation Turks and Moroccans in the Netherlands: Before and during the great recession. International Migration, 56(2), 97-116.

Wyn, J., \& Dwyer, P. (1999). New directions in research on youth in transition. Journal of Youth Studies, 2(1), 5-21.

Zhou, M. (2005). Ethnicity as social capital: Community-based institutions and embedded networks of social relations. In G. C. Loury, T. Modood, \& M. Steven (Eds.), Ethnicity, social mobility and public policy: Comparing the US and UK (pp. 131-159). Cambridge: Cambridge University Press.

Open Access This chapter is licensed under the terms of the Creative Commons Attribution 4.0 International License (http://creativecommons.org/licenses/by/4.0/), which permits use, sharing, adaptation, distribution and reproduction in any medium or format, as long as you give appropriate credit to the original author(s) and the source, provide a link to the Creative Commons licence and indicate if changes were made.

The images or other third party material in this chapter are included in the chapter's Creative Commons licence, unless indicated otherwise in a credit line to the material. If material is not included in the chapter's Creative Commons licence and your intended use is not permitted by statutory regulation or exceeds the permitted use, you will need to obtain permission directly from the copyright holder. 


\section{Chapter 2 \\ Prolonged Transitions: Early Tracking and Its Implications for Transitions}

\subsection{Introduction}

The bulk of transition studies define the initial transition point as when young people make a transition from compulsory education into the labour market, further study or inactivity. However, in stratified education systems in which pupils are streamed into different academic and vocational trajectories at an early age, the transition process begins much earlier, as educational tracking clearly shapes the future conditions of the transition process. Thus, in order to underline the retrospective nature of transitions, I will focus on the experiences of early educational stratification among native-born descendants of immigrants from Turkey in Amsterdam and Strasbourg. Studying this early transition provides an opportunity to unravel the working of social class, gender, ethnicity and the application and development of cultural capital in facilitating the transition decision.

Over the last two decades, numerous studies in the field of social stratification have confirmed the link between educational tracking and its consequences for the labour market (Van De Werfhorst and Mijs 2010). Various cross-national studies have demonstrated how the school-to-work transition process varies according to the level of stratification across education systems, as well as the occupational specificity in training systems where there is a tight match between skills gained in training and employer expectations in the labour market (Allmendinger 1989; Kerckhoff 2001; Mueller and Shavit 1998). Drawing on these findings, we can deduce that initial educational stratification will have significant consequences for pupils' future transitions. Therefore, this streaming is the first major transition that pupils experience. The first part of this chapter describes the Dutch and French education systems in detail, with particular emphasis on their respective stratification and streaming processes. TIES data will be used to describe the trajectories of native-born descendants of immigrants from Turkey in Amsterdam and Strasbourg. Examining these education systems and the rules of stratification first will help us to interpret pupils' motivations, orientations and practices. 
The second part of this chapter concentrates on the qualitative interviews with native-born descendants of immigrants, and respondents' reflections on the stratification process and their experience of it. It studies the extent to which separate educational streams pre-ordain the outcomes of transition by providing discrete institutional structures that produce different forms of capital that are crucial to labour market transitions. Furthermore, reflecting on the initial transitions untangles the role of the cultural capital that parents were able (or not) to provide during the transition process and how it varied across the two settings that we studied. We see how young people's motivation is influenced by their having a lower social class background and gendered values about education and work in combination with the support mechanisms they can rely on at home. This enables us to identify the early impact of social class, gender and the formations of cultural capital on the future transitions of young people as the tracking outcome has long-lasting effects.

\subsection{Stratification in Education Systems}

Compared to other aspects of educational systems, stratification has a strong impact on young people's transitions from school. Durkheim ascribed two main functions to education systems: socializing young people and selecting them for adult roles as citizens and workers (Emirbayer 2003). Therefore, the ideal of meritocracy is fostered through training, whereby education systems are assigned the responsibility of sorting young people into different occupational roles while supposedly eliminating the effect of social backgrounds on the outcome, thereby enhancing equality of opportunity (Lauder et al. 2006). However, due to persistent educational inequalities, there is a debate on whether education systems remove or reproduce inequalities. While the controversy about the reproductive versus the democratizing effects of education systems persists, schools continue to operate as legitimate "sorting machines", selecting students for their future occupational roles. On the one hand, schools officially stream students into different educational tracks based on "merit". On the other, a subtle, covert differentiation operates through parental social background which may lead parents to make better or less well-informed choices regarding schools or subjects, which translate into advantages (or disadvantages) for their children.

The most official of these two sorting mechanisms is educational stratification through streaming into tracks. Allmendinger (1989) defines educational stratification as the designing of education systems to divide pupils into different vocational and academic tracks with varied outcomes and rewards. Stratification decisions are officially based on meritocratic selection, such as tests and student grades. Previous studies have also associated educational stratification with the occupational specificity of vocational tracks. Mueller and Shavit have shown that most stratified education systems also provide vocational education that offers training in occupation-specific skills that are recognized by employers in the labour market (Mueller and Shavit 1998). Moreover, it has been argued that in highly stratified systems with vocational specificity, vocational students experience a smoother 
transition to the labour market (Kerckhoff 1995; Maurice et al. 1986; Mueller and Shavit 1998). Nevertheless, this condition also depends on the labour market conditions at the time of the transition. In the current study, the Dutch education system is classified as being highly stratified, providing occupation-specific vocational training through a combination of in-school training and intensive internship periods. In contrast, the French system is classified as being less stratified, with different forms of vocational training encompassing both apprenticeship programmes and school-based training with modest internship periods (leading to the BEP diploma) (Mueller and Gangl 2003). There now follow descriptions of the streaming processes in the Dutch and French education systems in light of the abovementioned theories of stratification. Each stage of these educational trajectories is augmented by descriptive information on the educational experiences of descendants of immigrants from Turkey using the Amsterdam and Strasbourg TIES data. The data provides rich and detailed educational histories for all respondents that help to describe educational flows.

\subsubsection{Streaming in the Dutch Education System (TIES Data Analysis)}

In the Netherlands, compulsory education usually starts at the age of four with primary school (basisonderwijs). Although there are no formal educational provisions for pre-school children, childcare facilities such as playgroups or day care are available. Working parents making use of these facilities may receive certain benefits based on their income level (Eurydice 2007). Previous studies have shown that preschool attendance is low among descendants of immigrants (Crul and Doomernik 2003). According to the TIES data, only $15 \%$ of native-born descendants of immigrants from Turkey living in Amsterdam reported having attended school before the age of four, and the mean school starting age is $3.96 .^{1}$

In the Netherlands, pupils are streamed into different educational tracks around the age of 12 when they enter secondary school. Previous studies have therefore classified the Dutch education system as "highly stratified" (Van De Werfhorst and Van Tubergen 2007). The tracking decision is generally based on both the scores of a test, known as the CITO test, taken in the last 2 years of primary school and the advice given by the primary school teacher. ${ }^{2}$ While it is argued that the test score is the most decisive element in the streaming decision (Luyten and Bosker 2004), teachers can greatly affect the choice of educational stream by over or under-advising (Hustinx 2002). After streaming, students attend a "bridge class" (brugclass) for one

\footnotetext{
${ }^{1}$ Since 2000, the government has provided opportunities for early education for children of parents with education or language disadvantages (Eurodyce 2007). However, most of the respondents did not take up this opportunity.

${ }^{2}$ Eighty-five percent of Dutch schools participate in the CITO test, though some do not (Eurydice 2008).
} 


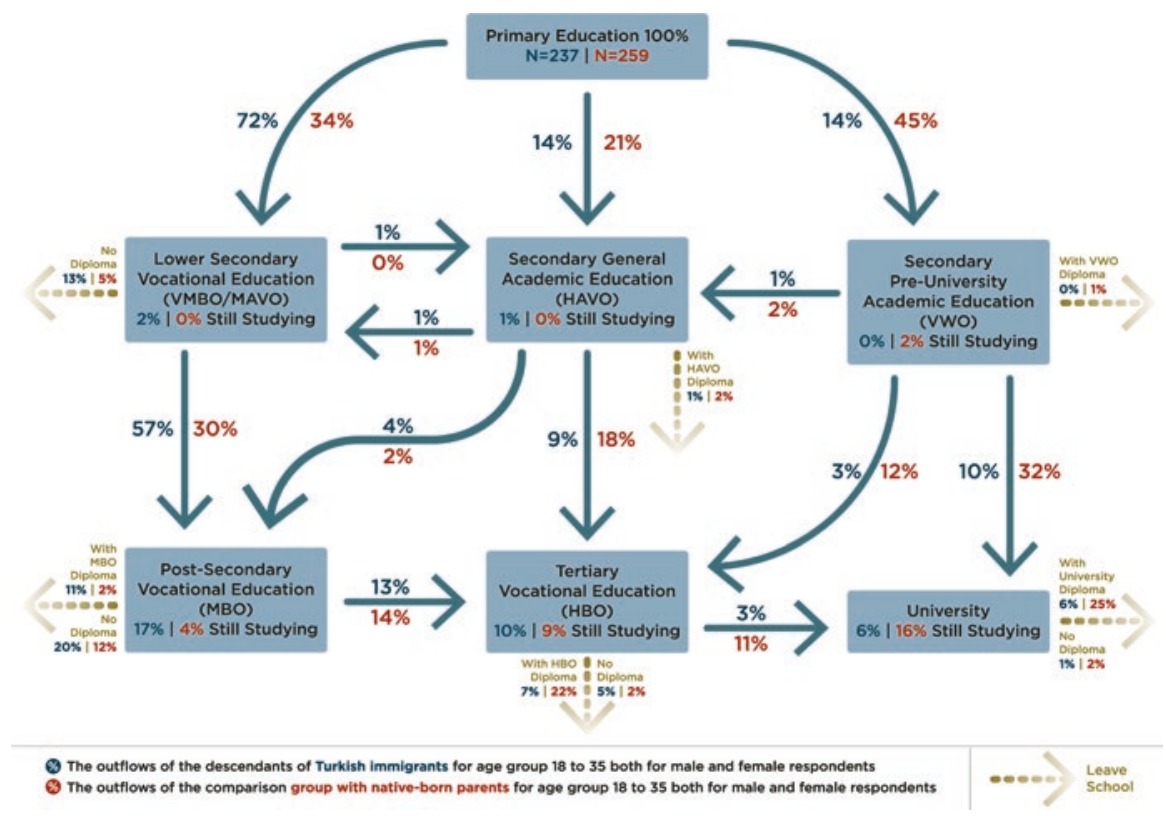

Fig. 2.1 Respondents' routes through the Dutch education system. (Source: TIES Survey 2008)

or 2 years, where they are given the opportunity to change track. After the bridge year, students are selected into a secondary education track. These tracks are divided into three main streams with varying orientations, durations and levels of selectivity. Each track provides access to different higher education opportunities (see Fig. 2.1). The first track is the vocationally-oriented lower general track (voorbereidend middelbaar beroepsonderwijs, or VMBO). In the past decade, all the vocational tracks, namely lower vocational education (VBO) and the lower general track (MAVO) were merged to form VMBO. This track now offers four separate learning pathways, ranging from $\mathrm{VMBO}$-basis (the most basic) to $\mathrm{VMBO}$-theoretic, the most advanced or selective stream. ${ }^{3}$ This vocational education lasts 4 years and prepares pupils for post-secondary vocational education and training (middelbaar beroepsonderwijs, or MBO) (see Fig. 2.1). The second stream is the general intermediate track (hoger algemeen voortgezet onderwijs, usually referred to as HAVO), which lasts 5 years and gives pupils access to higher professional education, also referred to as tertiary vocational college or education (hoger beroepsonderwijs, or $\mathrm{HBO}$ ). The third and most selective educational track is the pre-university track (voorbereidend wetenschappelijk onderwijs, or VWO). The pre-university track takes 6 years and grants students direct access to university education (wetenschappelijk onderwijs, or WO). Despite this early stratification process, the Dutch education system does allow for mobility between different tracks during secondary education. As a result of the

${ }^{3}$ In the TIES survey, respondents had been educated under both the old and the new systems. Figure 2.1 uses the new stream name, but includes those who attended MAVO and VBO. 
"bridge year", the track decision can be modified and pupils can also try to switch tracks throughout secondary school. VMBO students can transfer to HAVO in the fourth year of their study, and HAVO students can access VWO during fifth grade.

Figure 2.1 depicts educational flows in the Dutch education system using the TIES sample for Amsterdam. In this figure, the streams illustrate the flows of students. The figure should be read as $100 \%$ of the students entering the system and shows us how they are streamed through the system. Suárez-Orozco and SuárezOrozco (2009) described streaming in the US education system using the metaphor of a "pipeline" to illustrate how students "leak" from the education system.

Here, the intention is both to clarify the tracking system in the Netherlands (Fig. 2.2 refers to France) and also to show which pathways young people take in their educational trajectory. It incorporates all the respondents of the TIES Survey: the statistics in black represent the sample of native-born descendants of Turkish immigrants and those in red represent the comparison group, respondents with native-born parents, to give an indication of the trends within the general population. Those who hadn't left the education system remain clustered in the boxes depicting their current education level. Those who had left the education system are in the 'leave school' box. After primary school $72 \%$ of native-born descendants of immigrants from Turkey were tracked into VMBO, while 14\% pursued HAVO and another $14 \%$ entered VWO. ${ }^{4}$ Even though the system allows for some permeability, when we look at intra-trajectory movements, not many students experienced mobility across secondary educational tracks: for example, $1 \%$ of all these respondents experienced upward mobility from VMBO to HAVO, while $1 \%$ underwent downward mobility from HAVO to VMBO, and $1 \%$ experienced downward mobility from VWO to HAVO. The distributions are strikingly different for the comparison group with native-born parents, where we see that $34 \%$ accessed the vocational track, $45 \%$ accessed VWO and $21 \%$ entered HAVO. Mobility within tracks was also low among this group during secondary education.

After graduating from lower secondary school, pupils from the VMBO track begin post-secondary vocational training at an MBO, as a VMBO diploma is not a qualification in itself but only lays the foundation for vocational training. In the Netherlands, MBOs provide school-based vocational training with lengthy internship periods. MBO comprises four different qualification levels: the lowest two levels (niveau 1 and niveau 2), do not require diplomas or prior qualifications for entry. Furthermore, MBO-n2 is set as the minimum qualification (startkwalificatie) for entering the labour market. MBO level 3 and 4 (niveau 3 and niveau 4) both require a VMBO diploma.

Furthermore, Dutch vocational training provides substantial hours of internship experience, during which young people gain experience of their future occupations. Some studies therefore describe the Netherlands as a country with employment logic (Iannelli and Raffe 2007), as there is a strong coupling between the skills gained in the work place and labour market requirements, giving pupils considerable transparency with respect to their credentials. In the coming sections we will

\footnotetext{
${ }^{4}$ These are the final tracks that students enter after the bridge year, so this figure excludes the stratification prior to the bridge year.
} 
discuss how this job experience has the potential to lead to the development of different forms of capital among the respondents.

According to the TIES data, streaming works as most students pursued their institutional trajectories, with the exception of the $13 \%$ of respondents with Turkish immigrant parents who left school before entering MBO. However, the majority of students followed their tracks into the assigned institutions, and this was especially the case among those in higher general (HAVO) or pre-university (VWO) tracks. The Dutch education system also provides channels for those who received vocational education to attend university. Graduates of post-secondary vocational training (MBO) can access higher professional education colleges (HBO), and even enrol at university after graduating. In practice, those with any kind of MBO n-4 diploma can gain access to all tertiary education institutions. However, they will still have to study for another 4 years to obtain a tertiary professional degree (HBO), and an additional 2 years if they would like to acquire an MA. As a result, even though young people selected into vocational tracks are given this opportunity, they would have to spend an additional three to 5 years to achieve a higher education diploma.

In a recent study using the Dutch national data set, Tieben and his colleagues (2010) showed that the majority of pupils pursue the educational trajectory they were initially streamed into and only a minority switch tracks and achieve upward mobility. According to a recent report from the Ministry of Education, 14\% of MBO graduates went on to graduate from a HBO college (Altinyelken et al. 2010). In the TIES data for Amsterdam, $13 \%$ of the respondents accessed $\mathrm{HBO}$ via $\mathrm{MBO}$, although this only shows attendance at an HBO rather than attainment rates. At the time of the TIES survey, nearly half of the HBO students were still at school, so overall graduation rates are hard to determine. If holders of an HBO diploma would like to pursue their education in the same area of study, their qualification counts as a bachelor's degree, and they are only required to conduct 1 year of pre-master's preparation before studying for a master's degree. Unlike the French system, there are no institutionally recognized differences between higher education institutions of the same type in the Netherlands. However, among the two main types of tertiary education institutions, universities are perceived as being more prestigious than vocational colleges (HBO).

In the TIES data for Amsterdam, the majority of respondents who had successfully accessed university education originated from VWO tracks. All in all, out of the $100 \%$ who entered the education system, $10 \%$ of the sample of native-born descendants of immigrants from Turkey and $29 \%$ of the comparison group enrolled in university after finishing VWO. 3\% of native-born descendants of immigrants and $11 \%$ of the comparison group accessed university through HBO (see Fig. 2.1).

\subsubsection{Streaming in the French Education System (TIES Data Analysis)}

In France, the education system is organized into three broad tiers: pre-school education, primary to lower-secondary education, and higher education. In contrast to the Netherlands, the French state provides public pre-school education, 
which begins at age three and marks the starting age for almost $99 \%$ of children in France. Previous studies have shown that participation in pre-school education makes a significant contribution to reducing the risks of failure or repeating classes during primary school (Duru-Bellat 2000). Primary school begins at age six, and is the first stage of compulsory education. According to the TIES data, native-born descendants of immigrants from Turkey living in Strasbourg follow similar patterns: $99 \%$ attended pre-school education, whereby the mean starting age was 3.08. Nevertheless, $42.7 \%$ repeated at least 1 year during primary school, compared to $27 \%$ of descendants of Turkish migrants in Amsterdam. The French education system provides a comprehensive education until the end of lowersecondary school (collège), when the most critical selection occurs. The last year of collège is known as troisième. At the end of this year, around the age of 15 , students are sorted into different academic and vocational trajectories. This process is called orientation, during which a "class council" (conseil de class) composed of teachers and school officials gather to decide which stream pupils should be assigned to. Class councils consult the family and also take student grades into account, as well as the outcome of the brevet des collège or BEPC exams. ${ }^{5}$ After these consultation rounds, the class council reaches a final decision that parents can appeal against (Durier and Poulet-Coulibando 2007). ${ }^{6}$ As a result of the orientation process, students are streamed into two lyceum-based tracks: academic or vocational. Academic lyceum lasts for 3 years. In the first year, students attend uniform training (seconde). At the end of seconde, pupils must choose between the general or technology tracks, which prepare them for the baccalauréat général (bac général) or baccalauréat technologique (bac tech.) diplomas respectively. Of the two, the bac général diploma is deemed the most prestigious, though both allow direct access to university or other higher education institutions, as well as to the preparation classes for the most prestigious universities (grandes écoles).

In contrast to the 4-year vocational training given in the Netherlands, French vocational lyceums provide only 2 years of training, combining general education with specific technical skills to prepare pupils for entry into the labour market. Once more, vocational education is divided into two tracks. Young people study either for the Certificat d'Aptitude Professionnelle (CAP) or the Brevet d'Etudes Professionnelles (BEP). The CAP diploma requires apprenticeship periods and is deemed less prestigious than the BEP diploma, which is a school-based vocational training programme with few internship periods. BEP holders can attend an additional 2-year professional lyceum to obtain the baccalauréat professional (bac pro.), which gives vocational students the opportunity to enter higher education. Furthermore, since the reforms of the 1980s, French lyceums have seen a significant increase in attendance as the number of young people gaining the baccalauréat has

\footnotetext{
${ }^{5}$ Although these diplomas are not required for entrance to high school, they may influence the decision-making process (Brinbaum and Cebolla-Boado 2007).

${ }^{6}$ Between 2000 and 2002, only $2 \%$ of parents appealed against a council decision (Durier and Poulet-Coulibando 2007).
} 


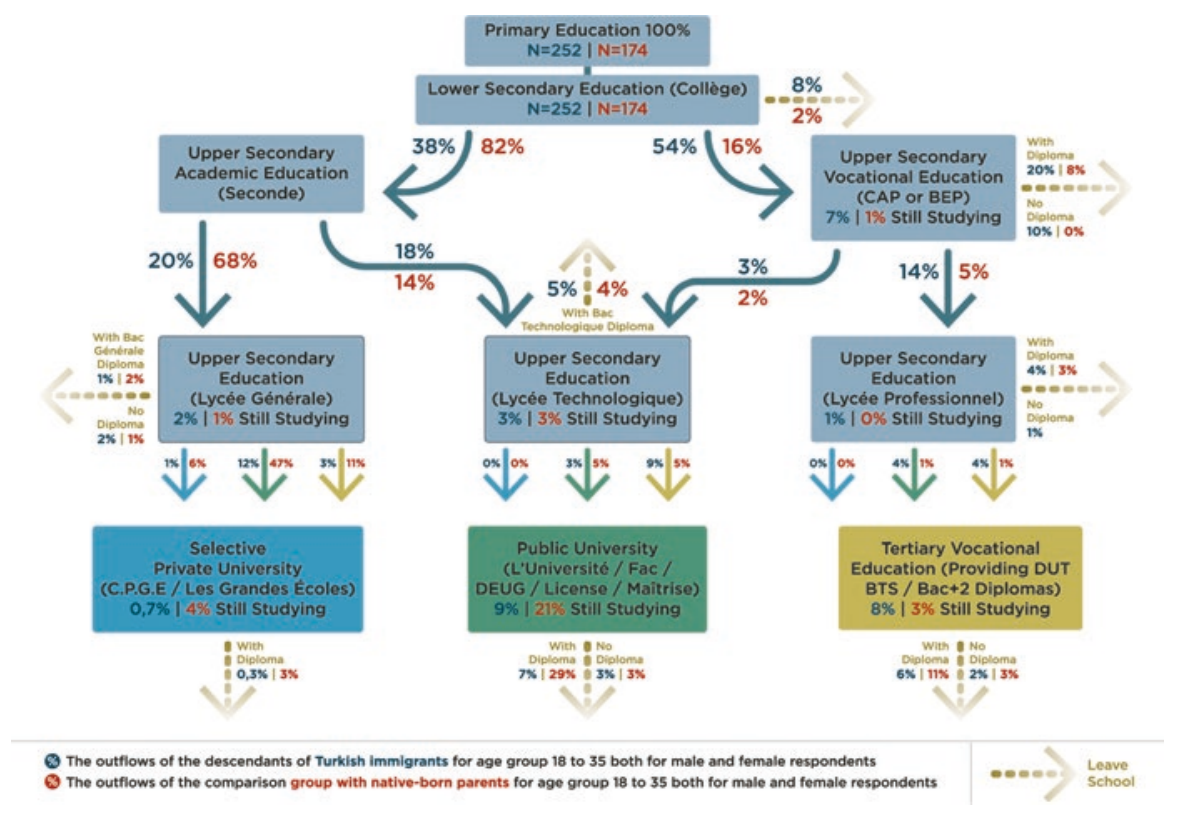

Fig. 2.2 Respondents' routes through the French Education System. (Source: TIES Survey 2008)

increased from $20 \%$ in the 1970 s to $62.5 \%$ in 2005 (Eurydice 2008). This growth was achieved by the creation and promotion of alternative forms of baccalauréat diploma, rather than an increase in the number of pupils obtaining the prestigious bac général (Duru-Bellat and Kieffer 2008).

Figure 2.2 illustrates educational flows among the TIES sample in Strasbourg. It shows that after lower secondary education (collège) 54\% of the sample of nativeborn descendants of immigrants from Turkey were assigned to the lower secondary education vocational track of upper secondary education which leads to either a CAP or BEP diploma, while $38 \%$ were assigned to the academic track (lyceums). $8 \%$ had already dropped out of education during or after collège. If we read the streaming graph and round off the percentages, the figures show that $54 \%$ of the students entered CAP/BEP, and, from there, $20 \%$ left education after attaining their vocational diplomas (either CAP or BEP), while $10 \%$ eventually left without a diploma and $14 \%$ attended lyceum. Among those who were selected into the academic track (38\%), at the end of the first year (seconde) $20 \%$ went to the general lyceum to study for the bac général and $18 \%$ entered technical lyceum to study for their bac tech diploma. Once more, these trends contrast with those of the comparison group: the majority of French-origin respondents (82\%) entered the academic track while only $16 \%$ entered the vocational track, and only $2 \%$ left education after collège. Among those who went to an academic lyceum, the majority (68\%) enrolled in general lyceum and $14 \%$ went to a technical lyceum. These trends accord with 
previous studies that show lower educational attainment among descendants of Turkish immigrants in France (Brinbaum et al. 2012; Silberman et al. 2007).

In France, some higher education institutions are clearly more prestigious than others and there is rigorous competition (concours) for admission to certain universities (grandes écoles) (Kieffer 2008). A lyceum diploma (baccalauréat) is not sufficient to gain admission to one of these universities. Candidates must take supplementary exams and not only exam results, but the kind of lyceum diploma they hold is of crucial importance. ${ }^{7}$ Despite increased participation in higher education among the children of immigrants and working-class parents, these groups are still under-represented in the grandes écoles (Brinbaum and Cebolla-Boado 2007; Brinbaum and Guégnard 2011; Duru-Bellat and Kieffer 2008). Students wishing to access engineering and social sciences courses at a grande école must attend highly selective 2-year preparation courses (CPGEs) before the competitive exams. These courses mostly select bac général holders with excellent GPAs. However, regular universities (DEUG under the old system, lisans or master in the new system) are non-selective (with the exception of medical schools), just requiring a baccalauréat diploma. Additionally, the 2-year tertiary schools such as STS or IUT are also somewhat selective. IUT schools are intended to train good students with bac général or bac tech. diplomas for the university technology diploma (DUT). Students can progress from IUTs to do a master's degree or even to a grande école if their grades are high enough. STSs prepare students for the vocational tertiary diploma (BTS), and were initially designed for bac tech. holders, though they have become popular among all baccalauréat holders. One important reason for BTS's popularity is the dual study option (BTS and Alternance), whereby students combine work with study and experience smooth transitions into the labour market (Bidart and Pellissier 2002).

When we look at how young people continue their education after stratification, Fig. 2.2 illustrates that $18 \%$ of the native born descendants of Turkish immigrants in the sample went to lyceum tech; $3 \%$ were still studying at the time of the survey; $5 \%$ graduated with a bac tech diploma; $1 \%$ did not obtain a diploma and left education; $9 \%$ enrolled in semi-selective 2-year vocational colleges to obtain a BTS or DUT diploma (see yellow arrow) and 3\% went to university (green arrow). Students in general or technological lyceums follow pre-ordained patterns, with those holding a bac général preferring non-selective universities over vocational colleges. In contrast, those holding a bac tech. entered vocational colleges more often than universities. As in Amsterdam, most TIES respondents in higher education were still studying at the time of the survey, making it difficult to determine accurate completion rates for higher education. Nevertheless, among those who finished, we see that $7 \%$ of the descendants of Turkish immigrants left education with a university diploma and $6 \%$ obtained a vocational tertiary education diploma (BTS/DUT) compared to $29 \%$ and

\footnotetext{
${ }^{7}$ Duru-Bellat and Kieffer (2008) show that in the 1975-1980 birth cohort access to a prestigious Grande École is $7 \%$ in the entire cohort while this percentage increases to $16 \%$ among bac général holders.
} 
$11 \%$ of the comparison group. From both groups only a small minority gained entry to a grande école; $7 \%$ of the comparison group and $1 \%$ of the sample of native-born descendants of immigrants.

\subsubsection{Comparative Analysis of the Dutch and French Education Systems}

We have seen that the Dutch education system streams a large majority of nativeborn descendants of immigrants from Turkey into vocational education. By contrast, in Strasbourg a considerable group (38\%) accessed academic training. This finding accords with the TIES research as a whole, which also encompassed Paris and Rotterdam data sets (Crul et al. 2012). Nevertheless, many studies have highlighted the descendants of immigrants from Turkey living in France as among the most disadvantaged second generation groups (Brinbaum et al. 2012; Silberman et al. 2007). However, when compared to the trends of stratification in Amsterdam, those in Strasbourg still seem to do better academically.

With regard to permeability, or the extent to which pupils can move across tracks, the majority of young people seem to continue their institutionally pre-conditioned educational pathways in both countries. In Strasbourg, only 13\% of the entire sample of native-born descendants of immigrants from Turkey accessed university via the long vocational track compared to $8 \%$ who accessed university or BTS via professional lyceum. Thus, even though the French system is classified as being less stratified and more comprehensive due to its later tracking, the outcome of the process has long-term implications in Strasbourg just as it does in Amsterdam. Despite differences across the systems, this shows that the tracking moment is crucial in the trajectories of young people in both settings.

Both the effect of tracking on transition and the permeability of tracks are two crucial issues for the interpretation of the qualitative data. Bol and Van de Werfhorst (2013) have recently illustrated that, while a high level of tracking in a national education system leads to better labour market allocation for young people, it also contributes to unequal educational opportunities since social class background has a greater effect on tracking in such systems. The following analysis of the in-depth interviews seeks to discover how young people in both cities relate to their initial tracking decisions, the role played by their parents and significant others and the forms of capital they could rely on during the tracking process.

\subsection{Transition Experience in Amsterdam and Strasbourg}

SERDAR: It's not like I chose between MAVO or HAVO, I was sent to MAVO because this was my level. 
Is it possible to say that the respondents in Amsterdam "chose" either a vocational or academic track? The majority of the participants in the qualitative study argued that their test score ${ }^{8}$ at the end of primary school (CITO) was the most significant determinant in their streaming. At that point of stratification, hardly any of the pupils referred to their motivations or orientations regarding schooling. For them, their track reflected their "education level" rather than their choice. Hardly any of their parents had been actively involved in the decision-making process. Hence, according to the respondents, the "choice" had been made by the "school and/or the test score" on the basis of "merit". Those respondents who had been high achievers throughout primary school scored well in the CITO test and thus made a direct transition into academic tracks, due to either their high grades or their prior placement in the "smart kids" clusters. Other pupils were mostly advised to enter the vocational track, where they remained unless teachers or significant others intervened in their educational destinies during their later school trajectories, such as in bridge year.

Gülden, the youngest child of Turkish immigrant parents, was initially tracked into vocational education. The part of her educational career that she particularly enjoyed was her apprenticeship and work experience and making a smooth transition into the labour market after receiving her MBO diploma. Among her siblings, she was the only one who acquired a vocational diploma, and is hence the highest achiever.

INTERVIEWER: What do you think about the stratification process at the end of primary school?

GÜLDEN: In fact, it is a good system, since everybody receives training at his or her own level.

INTERVIEWER: Do you think that people are sent to the right levels?

GÜLDEN: Well (pauses) I hear that students receive high grades but they are advised into lower tracks. I didn't experience anything as such. But still there is the bridge year. You are given a chance to do HAVO during this year.

Gülden underlines the two compelling institutional discourses in the Dutch education system: The first is that the streaming decision is based "almost entirely" on educational success, and hence everyone is sent to their "own level" of education; the other is that the system provides opportunities to switch tracks later. This discourse was echoed among other respondents.

Hakan had been tracked into the vocational stream and was a last-year MBO student at the time of the first interview. When asked about tracking, he associated "test results" with "capacity", meaning whether a student is able to manage a given

\footnotetext{
${ }^{8}$ The CITO test was first used in the Netherlands as an admission criterion in 1968 and its usage has continued to increase ever since. All of the respondents of this study confirmed participating in the CITO test. In order to avoid association with grades or IQ tests, CITO uses a grade scale ranging from 500 to 550. It is not possible to fail the test and each pupil's performance is converted to a grade between 500 and 550. Pupils who score between 501 and 520 are advised to follow basic vocational training (VMBO basis), while those who score between 545 and 550 receive an advice for pre-university education (VWO).
} 
track, and he also relates "smartness" to attending an "academic lyceum". Hakan defines the role of (education) systems as sorting people into appropriate levels.

INTERVIEWER: What do you think about the stratification process at the end of primary school?

HAKAN: I think it is good because they do a capacity test; they check your level. Can this boy or girl make it? Then comes the advice. I think CITO is most important; it shows what you (can) do.

INTERVIEWER: Do you think the selection is done fairly?

HAKAN: I think so, because if it was like Turkey... I mean, whomever I ask in Turkey, they say they are doing academic lyceum. I ask myself; are these people that smart? Or is there no system?

Moreover, the pledge that pupils will always have the opportunity to prolong their studies and upgrade their trajectories if they improve their educational success over time is successfully transmitted by teachers. Tülin's mother had serious health problems during the CITO period, so she scored poorly in the exam, and was advised to follow the vocational track. Her aim was to reach HAVO. Her teachers convinced her that she could always pursue her studies in the future. The structure's restrictions and the pupils' varying motivations were balanced by the discourse of flexibility embedded in the system. On the one hand, the premise of flexibility is committed to re-introducing "agency" into educational decision-making, and on the other hand it emphasizes the agent's responsibility in shaping their educational career. These discourses were internalized by my respondents and are evident in their accounts of their own educational careers. Even though some students questioned the accuracy of CITO in measuring educational capacity, they were generally confident that the selection process functioned quite directly on the basis of one's test score or "merit".

In Strasbourg, the strong emphasis on merit and the tight coupling between test scores and streaming decisions were not as evident in respondents' accounts, while orientations and future motivations regarding work or studying seemed to play a significant role. In Strasbourg too, the transition decision was primarily based on the pupils' grade point average (GPA) during lower-secondary education (collège). ${ }^{9}$ However, the respondents also talked about their orientations and motivations with respect to the tracking decision. In the respondents' experience, all of the pupils had selected institutions they would like to attend and this selection was evaluated by the class council on the basis of their educational history in the institution.

In the academic track, the high-achieving students once more made a direct transition into academic lyceum. Can and Ayla had scored remarkably high grades throughout primary school and collège, and were the highest achievers in their class. Can had even skipped a year during primary school. During the orientation process, they were directly advised to attend a general lyceum. The patterns were more mixed for students with an average GPA, some of whom qualified for the academic track. One group of students had good grades and families who encouraged them to take the academic track. Furkan had above-average grades throughout collège and was advised by his cousin, who attended university and knew how the system

\footnotetext{
${ }^{9}$ The grades are calculated based on the yearly average in college over 20 points. For example 12 over 20 is the minimum a student has to achieve to gain access to general lyceum training.
} 
worked, to attend an academic lyceum. He said he would have chosen the vocational track if she hadn't influenced his decision. Likewise, Selvi and Sevgi were steered towards the academic track by their fathers, who were well informed about the education system. The striking role played by families or significant others will be studied in the following sections.

Among the vocationally tracked students, while the class council rejected the academic track selection of some of the students, other students preferred to take vocational tracks despite having good enough grades for the academic track. These students raised various concerns that led to this decision. First, they weren't certain whether the class council would agree with their choices. Second, they were uncertain of the outcome of an academic track, and unsure whether, if they failed to win a place at university, they would still be able to enter a profession. In the end, many of these students opted for vocational lyceum (leading to BEP). Most of these students expressed pro-work orientations. This is also a gendered trend. Boys in particular felt more pressured to learn a trade and earn their own income in order to become more independent. Selahattin was the ninth child of a first-generation family. Hardly any of his older siblings had studied beyond vocational school. Even though he had very good grades for French during primary school, he didn't even consider studying in the academic track:

SELAHATTIN: My GPA was something like 13 or 14 [/20] at the end of collège.

INTERVIEWER: What was the decision of class council?

SELAHATTIN: Well, they just review your (school) selections and they give a report of the final decision. In my case, they said nothing because I had already chosen BEP in construction (vocational track) and they were OK with it.

INTERVIEWER: How did you choose BEP construction?

SELAHATTIN: Well I had heard about the job and liked it. And my grades, well, they were OK, but I wasn't sure how far I could continue with them.

INTERVIEWER: So you had sufficient grades to access the academic track?

SELAHATTIN: Well, I am not sure, but also after general (academic lyceum), you have to continue two to three years. I don't know, it was hard.

INTERVIEWER: What did your parents say?

SELAHATTIN: Nothing. They said do what you want to do.

According to students like Selahattin, the academic lyceum and the baccalauréat diploma were vague options that entailed too much risk. Cengiz, another pupil who had good grades but followed the council decision to pursue the vocational track highlighted this uncertainty "you can't do anything with a bac; you don't have any occupation".

However, some of these students pursued their education with a vocational baccalauréat and some even entered tertiary education. Such students decided to continue on to the next level when they scored high grades and their teachers advised them to try. Having obtained a vocational diploma (BEP) and avoided the risk of failure, they moved on to the next level to study for more diplomas, hoping this would increase their chances of employment. Again, credentialism came into play, even for students who were initially wary of entering the academic track. Despite the earlier emphasis on gender, similar working-class values were also discernible among the female pupils. Şebnem's GPA was also 14-15/20 in the last year of collège. Şebnem 
had first-generation immigrant parents, who could barely assist her education. Even though 12 was a high enough score for academic lyceum, Sebnem preferred to do vocational training:

ŞEBNEM: I wasn't a great student. My grades were average, 14-15 over 20. They weren't 18 or 19. I was just above average. But I was a good student, had good relations with teachers. I could have gone to general lyceum. But I didn't want to. Because, you know, you make a direct transition to university. Back then I didn't think of university. Back then I thought a vocational degree would be sufficient, you know. But now it's different; the population grew, the degrees became less valuable. Back then I thought BEP would be enough for a good job. To earn a trade ... The class council approved my decision, because everyone wanted to do a bac, they were happy that some people were choosing vocational study. A bit sneaky, right? They didn't warn me or anything...

Şebnem went to vocational school with a close friend. After they had obtained good grades in the vocational track and acquired a BEP diploma, they were advised to do a vocational baccalauréat. Having got their bac, they decided to enrol in university. In fact, Şebnem's ambition to study further was influenced at every step by her risk-averse attitude; she was cautious about taking one step at a time and climbing the ladder gradually by making sure that each step was guaranteed, and she also received considerable support from her peers, teachers and family.

Comparing the experiences of the respondents in two distinct systems we see that while the postulation of "meritocratic selection" dominated the discourses of respondents in Amsterdam, the merit argument was not as straightforward in Strasbourg. In Amsterdam students had hardly any doubts about the returns of an academic track or its prestige; they were certain that higher degrees would lead to better labour market outcomes. Hence the tracking outcome was reasoned along a meritocratic discourse of whether one is able or not to access such tracks.

In Strasbourg, young people talked about their motivations or perceptions to study in a given track. This was primarily related to the fact that some of my respondents in Strasbourg had doubts about the returns of the academic track, which did not guarantee transparent returns in the labour market. They perceived the shorter vocational route as providing more directly job-related skills. This condition was also heavily circumscribed by the respondents' social class background and the gendered pressures to earn an income swiftly that were mostly felt by young men. While the social class background of the respondents in Amsterdam did not vary from those in Strasbourg, the education systems signalled different realities to both groups.

\subsubsection{Merit and Cultural Capital of the Parents}

Most respondents pointed to the concept of "merit" to explain their tracking decisions. Nevertheless, what merit actually is has been a subject of intense debate. Merit is often conceptualized as intelligence paired with effort (Luyten and Bosker 2004). However, subsequent studies have repeatedly shown that merit is neither free from social class nor by itself a determinant in educational outcomes (Lauder et al. 2006). In a recent study of children of immigrants living in the Netherlands, Van de 
Werfhorst and Tubergen (2007) illustrate that neither the pupils' academic ability nor their tracking decisions are solely based on merit, but are rather dependent on the social class of their parents. As a result, even though the Amsterdam respondents felt that the tracking decisions were based on "merit", this is not in fact independent of one's parental background and home upbringing.

Bourdieu argues that one's educational talent—-merit"-is "itself a product of an investment of time and cultural capital" rather than a "natural aptitude" (Bourdieu 1985) (p. 47). This investment is provided within the family habitus over time, though "the scholastic yield from the educational action depends on the cultural capital previously invested by the family." (ibid) (p. 48). As a result, it matters a great deal what kind of cultural capital is invested in the family and how this capital is valued by the education system. It also requires parents to spend time with their children in the family setting. Bourdieu talks about three forms of cultural capital: embodied, objectified and institutional. The most vital is the embodied form of capital, in which not only language but also certain behavioural patterns are incorporated into the body and mind of children over time. This does not require inculcation but can simply occur unconsciously. Academic diplomas or other cultural goodsthe objectified state of cultural capital — are defined and valued only by their relation to cultural capital. For Bourdieu, the match between the cultural capital inculcated at home and what schools expect in terms of cultural capital in the classroom explains the ongoing reproduction of middle-class advantage. This becomes evident in Deniz's account. Her first generation parents mobilized all their means to support her education, but fell short of providing an appropriate family habitus compared to some of Deniz's classmates. At primary school, Deniz's teacher asked one of her French classmates to help her out with her homework. Deniz would go to her friend's home and spend some time with her and her mother.

DENIZ: During primary school, my teacher tried to help me improve my grades. The girl sitting next to me was the best student in the classroom. The teacher asked her parents, who were both French, whether I could visit their house after school, like twice a week for one or two hours, in order to do my homework. They accepted and so I went. It was completely different from our house. In our house when we came home from school we would wash our hands, wait for my father to come from work and we would have dinner together. Then everyone would sit down and do their homework. As much as we could, you know. But in my friend's house it was much different. First her mother would prepare something for us to eat, like a small snack. Then she would ask us about our day and what we had done at school. She would ask one question to her and then one question to me. Then she would ask us to show what we had done at school, like the stuff in our school bag. We would repeat what we had done. This was not possible at our house. Plus I mean, they speak French, this is an incredible advantage.

Deniz's classmate and her French parents would perfectly fit Bourdieu's theory of middle-class reproduction of advantage. Clearly, due to their lower social class and migration background, the majority of immigrant parents from Turkey do not and cannot possess the same cultural capital as middle-class Dutch or French parents. Many migrants go through "a devaluation of non-recognition of their skills" (Erel 2010, p. 643). Research has shown how migrants encounter difficulties in translating their social and cultural capital at home to the host country when assisting their children's education (Hagan et al. 1996). 
Nevertheless, the question remains of how to understand the input of Deniz's parents or other immigrant parents in their children's education, and especially how they influence the decision concerning their child's streaming. In both settings, some Turkish parents tried to support their children's education through a positive attitude towards education, by choosing the right school for their children and providing external support mechanisms via family networks or elder siblings (Rezai et al. 2015).

The choice of school was one way in which parents could influence their children's education. Most parents in our study sent their children to schools in their neighbourhood. In both Amsterdam (Karsten 1994; Karsten et al. 2003) and Strasbourg (Fabert and Raluy 2002), a large proportion of immigrant families live in segregated neighbourhoods and attend local schools which reflect this population balance. Such schools are seen as an extension of neighbourhood ghettoization since most parents send their children to a "nearby" school (Karsten et al. 2003). In Amsterdam, $11 \%$ of students go to a school where the majority of pupils come from a non-Dutch background (Booi et al. 2009). This percentage goes up to 37\% in some of the older neighbourhoods in the west of the city, where most respondents resided (ibid). In Strasbourg also, most respondents and their families resided in majority-minority neighbourhoods (Fabert and Raluy 2002). Although education priority policies (zone d'éducation prioritaire (ZEP) have been in force in France for almost 30 years in order to fight poor education in deprived neighbourhoods, they have not produced as many positive outcomes as expected (Mellottee et al. 2010). When it comes to choosing schools, in the Dutch context, parents are given the freedom to choose their children's school (Karsten 1994). However, this right also leads to an increased concentration of children of immigrants at particular schools, which is compounded by the fact that most native-born parents remove their children from schools with high numbers of pupils with immigrant parents, leading to effective "segregation" (Karsten et al. 2003, 2006). In France, by contrast, parents are required to send their children to a school in their postcode area (Mellottee et al. 2010). However, this restriction leads to the formation of ghetto schools in suburban neighbourhoods, while native parents find alternative ways to manipulate their children's school choice via course selection or by sending them to private schools (Zanten 1997).

In line with these trends, one group of respondents' parents had developed cultural and linguistic capital by virtue of their earlier arrival in the Netherlands or France: these were the 1.5 generation parents. This extra time spent in local educational and/or occupational institutions helped these parents to develop what Bourdieu, in a more general description of cultural capital, calls "information capital" (Bourdieu and Wacquant 1992, p. 119). Although most of these parents were still not able to fully assist their children with their homework, they had become fluent in Dutch or French and possessed information capital which distinguished them from other parents with poor language skills or little idea of how schools or the labour market function.

The interviews showed that the common educational strategy of these parents was to send their children to prestigious schools with a low number of descendants of immigrants. Affecting the choice of educational institution in this way requires a 
certain amount of informational capital on the part of the parents. Karsten and his colleagues (2003) showed that while native-born parents tried to find schools that matched their home habitus, immigrant parents did not necessarily seek such a match. Instead migrant parents tried to avoid segregated schools with poor reputations and selected schools with good reputations. Several examples of this experience were found among the qualitative interview respondents: Hakan's mother arrived in the Netherlands at the age of 12, received vocational training and was working as a bus driver. Before Hakan started school, both his mother and her aunts researched the best schools in Amsterdam and sent him to one of them. Gül's father, who came to the Netherlands at age 15 and studied here, sent her to a prestigious primary school in south Amsterdam. Both of Bulut's parents came to the Netherlands as 12-year-olds, and moved from west to east Amsterdam in the hope of providing better educational opportunities for their children. Engin's mother arrived in Strasbourg at the age of 12, and Fahri's father at 14, and both their families lived in suburban districts. As they lived in segregated neighbourhoods where the majority of pupils at the local schools were children of immigrants, both parents sent their sons to private colleges. Veli's father had arrived in Strasbourg at the age of 13 and received some vocational training. When Veli started secondary education, he made arrangements to move to a village near Strasbourg where there was a prestigious school.

While involvement of some parents in school choice was common across both settings, there were stark differences in their involvement in the streaming process at the first transition point. Hence the choice of school did not always lead to parents being involved in the tracking decision, which shows the limitations of cultural capital in directly influencing the process. In Amsterdam, hardly any of the first or 1.5 generation parents were involved in the streaming decision process despite the efforts they had put into choosing their children's school. Having assured themselves that their children were in good schools, they displayed a rather conformist attitude towards the school's tracking decision. Gül's case illustrates both the cultural capital that having 1.5 generation parents can provide, and the limits of that cultural capital. Gül's father came to the Netherlands at the age of 15 and received some schooling here. He speaks fluent Dutch and works as a driving instructor. Through his conversations with his clients he decided to send Gül to a good (Catholic) primary school where she could develop good language skills in Dutch. As she highlighted in interview, she has a "posh" Dutch accent; "I speak Dutch like those Istanbulite girls in the Turkish TV series; you know, like (imitates an upper-class Turkish accent)." In the CITO test, she received the highest score in her class, making her eligible for the pre-university track (VWO). However her teachers advised her to choose the general academic track (HAVO) because she was too talkative and had an attention problem. In her account, she initially agrees with the teacher's opinion, but then highlights her and her parents' lack of awareness of the consequences of this decision:

GÜL: Actually, I was capable of doing VWO, but the teachers didn't think I was fit for it, you know, because they said that I had low concentration; I was too talkative. They were right. I am smart, but maybe I don't put my brain to good use (giggles). HAVO was so easy; I got all my exams by barely studying.

INTERVIEWER: How was your CITO test? 
GÜL: It was the highest in my class. It was VWO. I mean, I could have done VWO, but back then you didn't think of these things. I was 12 or 13, you know.

INTERVIEWER: How about your parents?

GÜL: Well, they were happy that I was studying at all. I would just stop by my parents at the end of each year. They weren't really (involved), you know.

Thus, despite their efforts to choose a good school, the prestige difference between HAVO and VWO went unnoticed by her parents according to Gül. As she mentions in her quote, Gül hardly needed to make an effort during HAVO and passed all her exams with ease. She was clearly able to study in the most prestigious academic track. At the time of the interview, she was finishing her HBO degree and considering pursuing a pre-master and then an MA degree.

By contrast, parents in Strasbourg who had information capital about the system were not only able to intervene in the choice of a school for their children, but could also influence their children's tracking decisions. Selvi, Ümran and Sevgi all had 1.5 generation parents who were well-acquainted with the higher prestige level of academic lyceum. Furkan and Veli were steered towards an academic track by their elder siblings or relatives. Once they had achieved the required grades at collège, family members were there to help them reach the academic track. Sevgi, who was a vocational tertiary school (BTS) student at the time of the interview, almost complained of her father's assertiveness with regard to academic lyceum.

SEVGI: I also have a twin brother, and since we went to collège, it was never in question that we would have to do (bac) général. My dad was obsessed about us going to university, and he knew the best way to go was through général (lyceum). He came here young, you know; he couldn't study because he couldn't speak French in the beginning. Now his French is great but he couldn't study enough. He has a good business and everything, but he wants us to study.

Sevgi's father provided full financial and emotional support for his children so that they could do well in education. Nevertheless, neither he nor the other supportive parents were informed, for example, about the preparation courses for the grandes écoles. Veli's father had sent him to a prestigious village secondary school that provided all sorts of cultural and financial support that he could not. Veli's uncle assisted him by advising with external supplemental courses, and they made sure that Veli attended a general lyceum in the academic track. After receiving his bac général, Veli went to university to study public administration, since this was what all of his friends were doing. He discussed his educational choices:

VELI: Well, anybody can go to university. There is no problem there. As long as you have a bac diploma of course. But, you know, they have a hidden system. Of course, a university diploma is not bad; it shows that you have a certain level of education, as well as a certain cultural standing. But, you know, there are these schools that the statesmen and MPs attend.

INTERVIEWER: You mean the grandes écoles?

VELI: Yes, exactly. For example, in Strasbourg there is one famous one; ENA. I mean, for people like us, it is impossible to enter these (schools).

INTERVIEWER: Why?

VELI: Well, our parents came here as immigrants. My grandfather came here first. My father was 13 when he came. He did vocational school here. He speaks very good French. He started his own business, and he achieved a lot. I mean, he does everything 
for his family and his kids. But it's my mum who was at home, raising us, and she speaks no French. I mean, at home we all speak Turkish. Yeah, we went to school, back and forth, but we achieved everything on our own. University is as much as we can achieve. For our kids, it will be different, since we know about these schools now. During lyceum, I wasn't even aware that they existed. After I found out, I considered trying, but then I thought it would be too difficult.

Bourdieu also refers to cultural capital as informational capital since it relates to having symbolic information about the rules of the field (Bourdieu and Wacquant 1992). We have seen that some immigrant parents have developed some cultural capital with respect to how the education system functions, thanks to their early exposure to the host countries, their relations and exchanges in education and the labour market. Yet the composition and magnitude of this capital is rather limited when it comes to influencing their children's educational trajectories. This limitation was also enforced by the rules of the (tracking) game in the education systems. How parents with comparable levels of cultural capital could influence the tracking decision varied significantly across settings based on the rules of the field: in Amsterdam, the parents' role was limited to school selection, while in Strasbourg, parents were more able to manipulate their children's orientation and the school's decision during the streaming process at the end of collège.

\subsubsection{Teachers as 'Significant Others'}

When studying the educational and occupational mobility of second-generation groups, Portes and Fernandez (2008, p. 26) emphasized the role of persons they called "really significant others". These include teachers, counsellors, friends or family members, who know the rules of the game in the education system (therefore possessing information capital) and intervene in the educational decisions of the second generation to turn these rules to their advantage. Especially in the absence or limitation of parental cultural capital, some teachers played a significant role in overturning the educational destiny of pupils in both settings.

In Amsterdam, Serdar and Tugba were able to transition to VWO and HAVO respectively during their bridge year, thanks to the advice of their primary school teachers. Similarly, Hamdi's teacher had already tracked him into a class of highachieving children in his primary school, which helped him get better grades in the CITO test. Both İsmail and Serdar had first-generation parents, who gave them little assistance with their education. They both went to a neighbourhood school. While Serdar had poor grades in primary school and a very low CITO score, thanks to his teacher's over-advice and the efforts of his German teacher in the bridge class, he was able to catch up with his courses and attend VWO. Serdar explains his early failure as his school's failure;

SERDAR: I think I went to a terrible primary school. Because of this, everything that I was supposed to learn in primary school my German teacher taught me in brugklas. I really owe it to him. 
Some of the teachers in Strasbourg also intervened in the streaming selection process. Both Deniz and Engin had grades that qualified them for entry into the academic track, but their selection was declined by the class council. Deniz's history teacher intervened in the decision, saying that the class council would only send Deniz to the vocational track "over her dead body". The teacher not only reversed the council decision, but also made sure that Deniz gained access to the most prestigious lyceum in Strasbourg by manipulating the choice of institution. In fact, the class council decision was made on the grounds that Deniz was a hard-working student who had only achieved high scores by making an immense effort in collège and would struggle to manage in general lyceum. Deniz reported that she found lyceum difficult, but nevertheless managed to graduate and enter tertiary vocational education (BTS). At the time of the survey she was a successful businesswoman. Similarly, Engin's teacher opposed the council's decision and arranged for Engin to attend a preparation year at a lyceum so that he could transfer to the academic track.

The interviews generally showed that in the absence of parental assistance or significant others, it was those with average grades, rather than the high achievers, who suffered from the system. In both settings, the system had a tendency to discourage average achievers. Family support could balance this effect, but if there was a lack of parental support, average students risked being under-advised into vocational tracks unless there was a teacher or other institutional actor on hand to support them.

\subsection{Social Trajectories and Habitus; Experiences of Respondents in a Given Track and How the Track Shapes Them}

Educational stratification not only streams students into distinct educational training, but the institutional environments which young people enter can also either reproduce or modify their habitus. Bourdieu understands habitus as the major dynamic by which structure and agency are intertwined in reproducing social conditions. However, this doesn't mean it is closed to modification or upward mobility, as he explains:

Habitus is not the fate that some people read into it. Being a product of history, it is an open system of dispositions that is constantly subject to experiences, and therefore constantly affected by them in a way that either reinforces or modifies its structure. (Bourdieu and Wacquant 1992, p. 133)

Having said that, Bourdieu immediately argues that young people will be more inclined to reproduce rather than transcend (ibid). Furthermore, he also introduces the concept of social trajectory, throughout which young people's 'initial capital' is subject to change (Bourdieu 1984) (p. 111). This section aims to point out that not only the tracking decision but also the tracking outcome provides young people with various different habitus that enable capital development in their trajectories. Clearly, this affects children of low-status parents who enter an academic track as 
their home environment will contrast with the one at school (Bourdieu and Clough 1996). Describing her social relations, Cemre, a successful HBO student, relates her lack of affinity with other students with immigrant parents from Turkey to their attending a $\mathrm{MBO}$;

CEMRE: I think we grew apart. I mean, there is a difference now. Because most Turks here, they do MAVO (vocational track) and then they do MBO (post-secondary vocational education). But those with HBO, they have a difference of "understanding"; how should I say it? A different world-view. We think more openly and they think more traditionally. About everything: work, relationships, education.

Cemre's higher education experience helped her to develop linguistic and cultural capital that is valued in the Dutch labour market. She has internalized dispositions such as independence and reflexive thinking as well as linguistic capital, all of which are vital to her upward mobility. Furthermore, Bourdieu discusses how one form of capital can be transformed into another as it reinforces itself (Bourdieu 1985). Students in higher education also receive the opportunity to convert their educational capital into social capital as they interact with more students from the majority group. Native-born descendants of immigrants from Turkey form a majority in secondary and vocational schools in certain neighbourhoods, but their numbers shrink drastically when they progress into higher education. Once there, some build lasting contacts with young people with native-born parents.

In Strasbourg, Can had gone to an elite academic lyceum with the help of his teachers. He had developed close friendships at school, and these were instrumental to his gaining practical information about how to enter a grande école. Most of his friends with high-status parents had entered the preparatory classes for the grandes écoles, while Can had gone directly to a non-selective bachelor programme at the University of Strasbourg as his parents did not know about the preparatory classes. Nevertheless, he sustained his contacts with his friends and, after gaining his BA, he applied to study information technology at a grande école in Paris where all his friends were studying. This differs from the role played by a "significant other" as Can converted his cultural capital to social capital as a result of attending an academic track. He was the only respondent in my sample who was able to attend a grande école. While entering an environment dominated by Dutch or French students with native parents might have had positive consequences for some respondents, for those who couldn't manage to adjust, it could also be detrimental. In Strasbourg, Ayla was a remarkable student throughout her primary and collège education. She even received a special prize at the mathematics Olympics. During her transition to lyceum, not only was she sent to the most prestigious institution, but was also placed in the highest educational stream, the scientific track (Baccalauréat scientifique in French). However, Ayla found her new school environment difficult to deal with as it contrasted sharply with the congenial ambiance of her collège.

AYLA: It (friendship with classmates) was very difficult. Everyone was in competition with each other. Nobody cared about friendship. Everyone was concerned with their own thing. If they had something to ask, they would come and ask you. But when they were done with you, they would just leave. And if you have a question, they would pretend to want to explain, but they just wouldn't care. They wouldn't want you to be better than them, you see. 
Most of the pupils at a scientific track prepare for the concours to enter preparatory classes for the grandes écoles or medical school, which Ayla wanted but she found it difficult to get used to the competitive environment. Her alienation from her peers was soon reflected in her grades and she failed the baccalauréat examinations in her final year. As a result she abandoned her dream of becoming a doctor and dropped out without a diploma. Aged just 18, she decided to marry her boyfriend, even though her parents were upset by the shift in her educational career. This is an example of "habitus clivé", a term coined by Bourdieu (1999, p. 511), whereby Ayla suffered emotionally from the mismatch between her previous habitus and the new one at her school. Working with the concept of habitus clivé among the socially mobile, Friedman (2016) underlines the significance of the speed of social mobility or the suddenness of habitus modification leading to such a cleavage, often resulting in emotional distress. In Ayla's case, the sudden change in educational habitus at such a young age led to an emotional breakdown which resulted in her dropping out of school. Hence not all respondents benefited from a change in their habitus and some had difficulty adjusting to their new habitus.

\subsection{Conclusion: Pre-conditioned Youth Transitions and the Role of Parents}

Studies on social stratification have repeatedly shown that tracking pupils has strong implications for their future educational careers and eventually for youth transition later on (Tieben et al. 2010; Van De Werfhorst and Mijs 2010). The analysis of TIES data confirms this trend and illustrates that in general my respondents were adversely affected by this tracking system both in Amsterdam and Strasbourg. Even though more respondents were able to reach the academic track in Strasbourg compared to Amsterdam, in both cities the majority of native-born descendants of immigrants were streamed into less prestigious vocational tracks. This tracking outcome largely determined the educational pathways of my respondents as only a minority managed to modify their initial track (cf. Tieben et al. 2010). The fact that tracking preconditions the educational pathways is a reality faced not only by descendants of migrants but also for the youth with native born parents (ibid).

In explaining the initial and long-term tracking outcomes, social class, mostly measured on the basis of parental education level, is a significant determinant (Van de Werfhorst and Van Tubergen 2007). Yet despite having parents with similar, lower educational backgrounds some descendants of migrants achieve higher tracking outcomes "succeeding against the odds" to varying extents in distinct settings (Schnell et al. 2013). Hence what remains to be answered is what most quantitative studies have fallen short of uncovering: what are the micro-level mechanisms in which social class functions in making a difference among young people who seem to have parents from a similar social class background? How does parental background influence the tracking decision in Amsterdam versus Strasbourg? Using qualitative interviews, I uncovered various mechanisms with regard to the rules of the educational tracking game and the varying amounts and forms of capital that 
respondents could rely on at home and beyond when decisions were being made regarding the educational track they were to be assigned to within the given structures.

In Amsterdam respondents attributed streaming outcome to their national test scores, rather than their own motivation or their families' resources. The prestige and high returns of Dutch academic education appear to be undisputed, hence respondents did not hesitate about attending an academic track if they were advised to do so. For the rest, the meritocratic discourse was largely internalized, especially by those who were happy with their initial tracking decision, whether they were in a vocational or academic track. This means that most respondents agreed with their tracking advice, saying that it was based on their test performance. Despite the varied cultural capital within the migrant community and parents' efforts to influence their children's educational trajectories by selecting certain schools, family and significant others in Amsterdam seemed to have very little influence on the transition decision. In Strasbourg, however, parents and extended family members with cultural capital were more able to affect the tracking outcome. The motivation of the respondents (and their families) also mattered in the French context. The system's lack of transparency led students to doubt the benefits of academic track education; hence respondents were uncertain whether going to university or vocational colleges would pay off on the labour market. This situation was exacerbated by the respondents' working-class background and gendered values. Coming from lowincome families, male respondents felt more pressured to gain economic independence. By the age of 15 they were already more inclined to select the vocational route in order to learn a profession rapidly and enter the labour market. Some students whose grades qualified them for the academic stream preferred to pursue a vocational track, and this decision was approved by the school authorities (which was very unlikely in the Dutch case). Hence in terms of overt mechanisms, it would seem as if social class and having cultural capital in the form of information capital had a more direct influence on the tracking decision in Strasbourg than in Amsterdam. This condition can easily apply to working-class youth with native-born parents since the findings point to resources that are not specific to an ethnic group. It is very likely that working-class children in Amsterdam are also subject to the Dutch system's strict tracking process and the parents of working-class children in Strasbourg may not possess enough cultural capital to influence the tracking selection procedure unless a teacher or a significant other with information capital intervenes. What remain unexplained are the covert mechanisms at play in Amsterdam through which middle-class native-born parents might manage to exert influence on their children's tracking outcomes. We have seen that some parents tried to select certain schools or neighbourhoods in the hope that they would yield better tracking outcomes but as we do not have a comparison group consisting of "middle class parents" in the qualitative study, these covert mechanisms remain unrevealed.

Studying the way in which parents played a role in the initial tracking decision using Bourdieu's cultural capital theory helps us identify how social class works in practice. First of all, studying the cultural capital of migrant parents requires us to look beyond middle-class bound descriptions of cultural capital (Skeggs 2004) and 
come up with alternative usages. It also shows that despite seeming to hold similar social class statuses in social stratification studies (cf. Van de Werfhorst and Van Tubergen 2007), migrant communities differ among themselves in terms of the forms of capital they possess. Such disguised differences are hard to catch in statistical research but are eventually revealed by using qualitative methods. Early exposure to the education and labour market system of the host country and speaking the host country's language all resulted in some parents developing cultural capital. Even though they have not been very socially mobile themselves, they have been able to transmit advantages to their children. This also exemplifies how parents and certain significant others played a crucial role with long-lasting effects early on in young people's social trajectories.

\section{References}

Allmendinger, J. (1989). Educational systems and labor market outcomes. European Sociological Review, 5(3), 231-250.

Altinyelken, H. K., Bois-Reymond, M. D., \& Karsten, S. (2010). Governance of educational trajectories in Europe: Country report the Netherlands. Amsterdam: University of Amsterdam.

Bidart, C., \& Pellissier, A. (2002). Copains d'ecole, copains de travail. Réseaux, 115, 17-49.

Bol, T., \& Van de Werfhorst, H. G. (2013). Educational systems and the trade-off between labor market allocation and equality of educational opportunity. Comparative Education Review, 57(2), 285-308.

Booi, H., Jong, I. D., Oirschot, L., \& Slot, J. (2009, September). De staat van de jeugd, Jeugdmonitor Amsterdam 2009 Amsterdam Stadsuitgeverij.

Bourdieu, P. (1984). Distinction: A social critique of the judgement of taste. Cambridge, MA: Harvard University Press.

Bourdieu, P. (1985). The forms of capital. In J. G. Richardson (Ed.), Handbook of theory and research for the sociology of education (pp. 241-258). New York: Greenwood.

Bourdieu, P. (1999). The weight of the world: Social suffering in contemporary society. Oxford: Polity.

Bourdieu, P., \& Clough, L. C. (1996). The state nobility: Elite schools in the Field of power. Stanford: Stanford University Press.

Bourdieu, P., \& Wacquant, L. J. D. (1992). An invitation to reflexive sociology. Chicago: University Of Chicago Press.

Brinbaum, Y., \& Cebolla-Boado, H. (2007). The school careers of ethnic minority youth in France: Success or disillusion? Ethnicities, 7(3), 445-474.

Brinbaum, Y., \& Guégnard, C. (2011). De l'orientation au sentiment de discrimination: Parcours de formation et d'insertion des jeunes issus de l'immigration. [Orientations towards feelings of discrimination: Education and transition pathways of young people with migration background]. Net.Doc 78, Cereq, Marseille.

Brinbaum, Y., Moguérou, L., \& Primon, J.-L. (2012). Les Enfants d'immigrés ont des parcours scolaires différenciés selon leur origine migratoire [Children of migrants have different educational pathways according to their migration origin]. Insee References Edition 2012: Immigrés et descendants d'immigrés en France, 43-59.

Crul, M., \& Doomernik, J. (2003). The Turkish and Moroccan second generation in the Netherlands: Divergent trends between and polarization within the two groups. International Migration Review, 37(4), 1039-1064.

Crul, M., Schneider, J., \& Lelie, F. (2012). The European second generation compared: Does the integration context matter? Amsterdam: Amsterdam University Press. 
Durier, S., \& Poulet-Coulibando, P. (2007). Formation Initiale, Orientations Et Diplômes De 1985 À 2002. Économie Et Statistique, 74, 143-159.

Duru-Bellat, M. (2000). Social inequalities in the French education system: The joint effect of individual and contextual factors. Journal of Educational Policy, 15(1), 33-40.

Duru-Bellat, M., \& Kieffer, A. (2008). From the Baccalauréat to higher education in France: Shifting inequalities. Population, 63(1), 119-154.

Emirbayer, M. (2003). Individuality and autonomy: Introduction Emile Durkheim: Sociologist of Modernity. Cornwall: Blackwell Publishing Ltd.

Erel, U. (2010). Migrating cultural capital: Bourdieu in migration studies. Sociology, 44(4), 642-660.

Eurydice. (2007). The education system in the Netherlands 2007. The Hague: Ministry of Education, Culture and Science.

Eurydice. (2008). Organisation of the education system in France. Paris: Ministry of Education.

Fabert, J., \& Raluy, P. (2002). Quel developpement urbain pour Strasbourg? (How is the urban development in Strasbourg?). Alsace. PCM le pont, 100, 19-21.

Friedman, S. (2016). Habitus clivé and the emotional imprint of social mobility. The Sociological Review, 64(1), 129-147.

Hagan, J., MacMillan, R., \& Wheaton, B. (1996). New kid in town: Social capital and the life course effects of family migration on children. American Sociological Review, 61, 368-385.

Hustinx, P. W. J. (2002). School careers of pupils of ethnic minority background after the transition to secondary education: Is the ethnic factor always negative? Educational Research and Evaluation, 8(2), 169-195.

Iannelli, C., \& Raffe, D. (2007). Vocational upper-secondary education and the transition from school. European Sociological Review, 23(1), 49-63.

Karsten, S. (1994). Policy on ethnic segregation in a system of choice: The case of the Netherlands. Journal of Education Policy, 9(3), 211-225.

Karsten, S., Ledoux, G., Roeleveld, J., Felix, C., \& Elshof, D. (2003). School choice and ethnic segregation. Educational Policy, 17(4), 452-477.

Karsten, S., Felix, C., Ledoux, G., Meijnen, W., Roeleveld, J., \& Van Schooten, E. (2006). Choosing segregation or integration? The extent and effects of ethnic segregation in Dutch cities. Education and Urban Society, 38(2), 228-247.

Kerckhoff, A. C. (1995). Institutional arrangements and stratification processes in industrial societies. Annual Review of Sociology, 21(1), 323-347.

Kerckhoff, A. C. (2001). Education and social stratification processes in comparative perspective. Sociology of Education, 74(1), 3-18.

Kieffer, A. (2008). Applying the ISCED-97 to France: Some issues and propositions. Education, $25,24$.

Lauder, H., Brown, P., Dillabough, J.-A., \& Halsey, A. H. (2006). Education, globalization, and social change. New York: Oxford University Press.

Luyten, H., \& Bosker, R. J. (2004). Hoe Meritocratisch Zijn Schooladviezen? Pedagogische Studiën, 81, 89-103.

Maurice, M., Sellier, F., \& Silvestre, J. J. (1986). The social foundations of industrial power: A comparison of France and Germany. Cambridge: MIT Press.

Mellottee, L., Becquet, V., Danic, I., Lepape, M.-C., Leroy, P., Loncle, P., \& Muniglia, V. (2010). Country report: France governance of educational trajectories in Europe. Amsterdam: University of Amsterdam.

Mueller, W., \& Gangl, M. (Eds.). (2003). Transitions from education to work in Europe: The integration of youth into EU labour markets. Oxford: England University Press.

Mueller, W., \& Shavit, Y. (1998). From school to work: A comparative study of educational qualifications and occupational destinations. Oxford: England University Press.

Portes, A., \& Fernández-Kelly, P. (2008). No margin for error: Educational and occupational achievement among disadvantaged children of immigrants. The Annals of the American Academy of Political and Social Science, 620(1), 12-36. 
Rezai, S., Crul, M., Severiens, S., \& Keskiner, E. (2015). Passing the torch to a new generation: A qualitative study of the highly educated second generation's receiving of parental support and giving of support to the younger generation. Journal of Comparative Migration Studies, 3, 12.

Schnell, P., Keskiner, E., \& Crul, M. (2013). Success against the odds: Educational pathways of disadvantaged second-generation Turks in France and the Netherlands. Education Inquiry, $4(1), 125-147$.

Silberman, R., Alba, R., \& Fournier, I. (2007). Segmented assimilation in France? Discrimination in the labour market against the second generation. Ethnic and Racial Studies, 30(1), 1-27.

Skeggs, B. (2004). Context and background: Pierre Bourdieu's analysis of class, gender and sexuality. The Sociological Review, 52(2_suppl), 19-33.

Suárez-Orozco, C., \& Suárez-Orozco, M. M. (2009). Educating Latino immigrant students in the twenty-first century: Principles for the Obama administration. Harvard Educational Review, 79(2), 327-340.

Tieben, N., de Graaf, P. M., \& de Graaf, N. D. (2010). Changing effects of family background on transitions to secondary education in the Netherlands: Consequences of educational expansion and reform. Research in Social Stratification and Mobility, 28(1), 77-90.

Van De Werfhorst, H. G., \& Mijs, J. J. B. (2010). Achievement inequality and the institutional structure of educational systems: A comparative perspective. Annual Review of Sociology, 36, 407-428.

Van De Werfhorst, H. G., \& Van Tubergen, F. (2007). Ethnicity, schooling, and merit in the Netherlands. Ethnicities, 7(3), 416-444.

Zanten, A. V. (1997). Schooling immigrants in France in the 1990s: Success or failure of the republican model of integration? Anthropology \& Education Quarterly, 28(3), 351-374.

Open Access This chapter is licensed under the terms of the Creative Commons Attribution 4.0 International License (http://creativecommons.org/licenses/by/4.0/), which permits use, sharing, adaptation, distribution and reproduction in any medium or format, as long as you give appropriate credit to the original author(s) and the source, provide a link to the Creative Commons licence and indicate if changes were made.

The images or other third party material in this chapter are included in the chapter's Creative Commons licence, unless indicated otherwise in a credit line to the material. If material is not included in the chapter's Creative Commons licence and your intended use is not permitted by statutory regulation or exceeds the permitted use, you will need to obtain permission directly from the copyright holder.

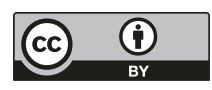




\section{Chapter 3 \\ Blurring of the Transition Point: \\ Combining Work and Study}

\subsection{Introduction}

Over the past few decades, youth researchers have argued that school-to-work transitions have become more complex and prolonged due to new conditions in European labour markets and education systems (Wyn and Dwyer 1999). One widely acknowledged reason for this prolongation is the expansion of higher education, which is increasingly accompanied by growing participation in part-time student employment. The fact that more young people are combining work with studying means that their education is overlapping their occupational career. This poses the question of when exactly the transition to the labour market begins and ends for young people (du Bois-Reymond 2009a). To gain a better understanding of transition experiences today, it is necessary to analyze the dynamic interplay of the multiple transitions that are taking place simultaneously (Schoon and Silbereisen 2009).

In order to scrutinize the complexity of transitions, I will study whether, and if so how, my respondents combine their studies with work throughout their trajectories in order to understand the influence of work-school combinations on the transition process. Previous studies have suggested that student employment is mostly undertaken for financial reasons, such as paying for tuition costs or sustaining a consumer lifestyle, and in order to gain the credentials needed to secure a full-time position in the labour market (Brooks 2006). Student employment practices familiarize young people with the world of work, where they can accrue occupational skills, orient themselves towards the labour market and discover more about what actually motivates them. However, working can also have negative implications for students' educational careers in the form of falling grades or even dropping out of education entirely, depending on the type of job, working conditions and hours of employment (McNeal 1997; Ruhm 1997). Consequently, student employment is in many ways a critical activity during the transition process. 
Research in the Netherlands and France has documented a significant increase in student employment since the 1990s. In the Netherlands, student employment (called a bijbaan in Dutch) refers to a student job for around $12 \mathrm{~h}$ per week during one's study programme. According to CBS statistics, in 1992 one third of students between the ages of 15 and 24 worked at least $12 \mathrm{~h}$ per week during the course of their studies. By 2001, this percentage had increased to more than 50\% (Lucassen 2003). Between 2001 and 2014, when the respondents of this study were still at school, the rate of working among all active students fluctuated between $50 \%$ and $60 \%$ (CBS 2012). Looking at older age groups, Riele and Siermann (2007) showed that $80 \%$ of Dutch students between the ages of 20 and 24 reported having a regular job for at least $12 \mathrm{~h}$ per week, with $60 \%$ of them working more than $12 \mathrm{~h}$. Similarly, in France, student jobs refer to both regular jobs for $12 \mathrm{~h}$ per week and small, irregular jobs (petit-boulots). According to the 1998 Generation Survey, $70 \%$ of students reported having had some sort of a job during their studies, although only $11 \%$ of these jobs were on a regular basis (Cereq 2001). In the 2004 Generation Survey, participation in student jobs had increased to $75 \%$ while regular employment had reached 17\% (Cereq 2007). Although these figures apply to the period when the respondents of the study were still at school, student employment continues to be a significant phenomenon in France. According to the most recent 2010 Generation Survey, $68 \%$ of students reported having a side job while $16 \%$ had a regular job and the remaining 52\% had a summer job (Cereq 2014).

As previous studies have shown that there is a lack of focus on student employment with regards to its impact on the occupational careers of 'second generation' groups (Kasinitz et al. 2008). There is very little research on the student employment patterns of the descendants of immigrants in the Netherlands and France. Nevertheless, certain trends are discernible in the existing statistics. First, the participation of descendants of immigrants in student employment has increased in the last few decades in the Netherlands, though these students are less likely to combine work and study compared to their peers with native-born parents (Lucassen 2003; Wolbers 2008). However, neither Lucassen (2003) nor Wolbers (2008) distinguish between immigrants and their descendants. As a result, it is not clear whether the descendants of Turkish immigrants combine work and study less often than the children of natives. In France, previous research has shown divergent patterns of student employment based on family socioeconomic standing. For example, the children of managers and executives are more likely to work in jobs related to their studies, and thus have better chances of transitioning to the labour market through these jobs, compared to children from low and middle-income families (Béduwé and Giret 2004). Lower status jobs also mean precarious working arrangements and more strenuous work conditions that are more likely to lead to drop out or failure at school in France (Pinto 2010).

First, I will delineate the structural contexts of student employment in Amsterdam and Strasbourg with a particular emphasis on the labour market context and student financing mechanisms in the years 2005-2009 when the respondents were interviewed. Second, I use TIES data to describe student employment practices among children of Turkish immigrants in Amsterdam and Strasbourg. Since financial 
reasons form the major motive for student employment, a detailed overview of the financial position of the students in both settings is provided. The descriptive analysis from the TIES survey is amplified with qualitative interviews to understand the motivations behind student employment practices and the implications of working while studying for the transition process. Accordingly, the chapter examines whether the work activity has different consequences in terms of the development of forms of capital, especially work-related social capital and information capital, and whether the experiences of young people vary across the two cities.

\subsection{Structural Contexts for Student Employment in the Netherlands and France from 2005 to 2009}

\subsubsection{Labour Market Contexts}

The growth of student employment in the Netherlands has primarily been interpreted as a sign of increased labour market flexibility (Van der Meer and Wielers 2001). Delsen and Poutsma (2005) have argued that increased flexibility in the working practices of the Dutch labour market has led to a rise in the number of temporary contracts and part-time employees. Accordingly, students are seen as one of the most eligible groups for jobs with flexible hours, temporary contracts and low wages - to the extent that in some cases they have even replaced senior workers with low education levels who require greater employment security and stability (Van der Meer and Wielers 2001). In the case of France, recent reforms to promote flexibility in the labour market have resulted in an increase in temporary contracts. However, the effect of this reform was to preserve reasonably high levels of job security among senior workers ("insiders"), but to lower them among new entrants, especially young workers ("outsiders") (Jamet 2006). Consequently, young people are more vulnerable to precarious working arrangements, such as short-term contracts and repeated periods of unemployment (Zdrojewski et al. 2008). Under such circumstances, student employment opportunities are limited and characterized by temporary contracts, flexible working hours and low job security. The French government has recently begun to use new legislation ${ }^{1}$ and official reports to promote student employment, identifying it as a means of gaining autonomy and professional experience while improving integration into the labour market (Bérail 2007). However, left-wing parties and student unions in France consider work-study situations as an indication of financial need due to a lack of sufficient government funding.

\footnotetext{
${ }^{1}$ For example, a law has been passed that allows universities to employ their own students in administrative positions at school (Bérail 2007).
} 


\subsubsection{Student Finance Systems}

Another factor in the proliferation of student employment in both countries are the reforms to their financial aid systems. In the Netherlands there has been a gradual transfer of financial responsibility from the government to higher education students through reforms in the financial system (Vossensteyn 1999) since 1986. Prior to 1993, the state provided a basic grant (basisbeurs) to all students older than 18 attending post-secondary vocational education (MBO) or tertiary education (HBO, WO), which was higher for students living away from home. The children of lowincome families received a supplementary grant based on a means test, ${ }^{2}$ and all students were allowed to take out extra loans. Furthermore, all students received a travel pass to use either during the week or on weekends. However, after 1993 this system changed with the introduction of performance-based grants (prestatiebeurs), which transformed both basic and supplementary grants into conditional grants. Students did not have to repay their grant if they graduated successfully, but should they fail to graduate, the grant would be converted into an interest-bearing loan (Eurydice 2007). Even before the reform, student organizations were claiming that educational grants were substantially below student expenditure (Vossensteyn 2002). Under the new measures, students had to take out loans with interest, depend on a parental contribution or take a student job. Most students preferred a part-time job to extra loans as they already faced the risk of having to repay their grant should they fail to graduate (ibid). The new legislation not only increased student employment, but also rendered students' socioeconomic background more significant. Students from privileged backgrounds could rely on parental support, while those from lower income families became obliged to depend on student employment or loans.

The French student assistance system has also been criticized for its inadequacy with regard to both the amount disbursed and the number of students benefitting from it. In France, unlike in the Netherlands, only students in tertiary education programmes (BTS or university) can benefit from scholarships, and only the children of low-income families can benefit from government assistance programmes. ${ }^{3}$ According to a survey by OVE, only $30 \%$ of French students reported having received some sort of student financing, most of whom came from low-income families (OVE 2006). According to the official report by Wauquiez (2006), most middle-class students are excluded from the collective aid system because they are not considered "poor" enough, and most of them resort to parttime employment to finance their expenses. However, state assistance constitutes the smallest proportion of income for all students-the highest contributor is the income gained from student employment (OVE 2006). In 2008 the student financial aid system was overhauled to make it more accessible. Under the new reforms,

\footnotetext{
${ }^{2}$ While the basisbeurs is the same amount for all students (around $€ 100$ ), the supplementary grant can bring scholarships up to approximately $€ 400$.

${ }^{3}$ There is a six-level system, in which a student's rank is determined by parental income, whether they live with their parents and the number of siblings studying. Those in Level 0 receive no aid and those in Level 6 can receive up to $€ 450$ per month.
} 
social criteria scholarships are dependent on the income of the parental household, the number of dependent children, and the distance from the household to the student's place of study (Eurydice 2008). Social criteria grants can be supplemented by merit aids based on students' grades or educational success and there is also a new national emergency fund for cases where existing funds are insufficient to cover financial needs. Additionally, a new student loan system was implemented in the academic year 2008-2009 with the aim of increasing access to such funding while also bringing diversity to the ways in which students finance their studies. The state now also provides funds for accommodation and food. Unlike in the Netherlands, where students must complete a certain number of academic credits per semester depending on their course of study to sustain their grants, French grants are not automatically converted into loans if a student fails to complete his or her academic programme.

\subsubsection{Education System and Labour Market}

As discussed in Chap. 1, the Netherlands and France differ from each other in terms of the ways in which individuals acquire occupational skills in the education system, and how these skills are recognized in the labour market. The Dutch education system has a strong vocational orientation, through which professional skills are acquired at higher secondary and tertiary vocational schools, and students are often expected to conduct rather long internships or traineeships (Mueller and Gangl 2003). Conversely, France has a less vocationally-oriented education system in which professional skills are gained mainly through on-the-job training (ibid). Despite new developments in vocational tertiary education in France, where the role of employers and internships are encouraged, (Powell et al. 2009), professional tertiary education and vocational tracks still typically require much shorter internship periods compared to the Netherlands (Pigeaud et al. 2009; Visser 2010). ${ }^{4}$ These differences may have an effect on student employment practices, as gaining work experience is more valued and even promoted by the education system in the Netherlands than in France. A study by Wolbers (2003) using EULFS, showed that, in addition to the higher levels of participation in apprenticeships or internships, student employment is also more common in the Netherlands than in France. High participation in internships, which are institutional forms of work-study combinations fostered by educational institutions and the labour market, creates and promotes student employment in the Netherlands.

\footnotetext{
${ }^{4}$ According to CEDEFOB's Vocational Education and Training (VET) reports, most vocational programmes in the Netherlands require at least $20 \%$ of study time to be spent working for a minimum of 6 months, while the internship requirement in France is only 4-6 weeks.
} 


\subsection{Work-Study Combination in Amsterdam and Strasbourg}

\subsubsection{Nature of Student Employment}

The TIES Survey is cross-sectional and only provides a snapshot of respondents' activities. Table 3.1 shows the distribution of activities reported by the descendants of immigrants from Turkey at the time of the survey. Since the current chapter is about student employment practices, the data analysis will only focus on students, who form $37.2 \%$ of the sample in Amsterdam and 30.1\% in Strasbourg. This group includes those who are combining work and study, doing an apprenticeship or only studying (marked in bold in Table 3.1). Those who are not studying will be excluded from the analysis.

Table 3.1 already demonstrates that more students in Strasbourg reported "only studying" in comparison to those in Amsterdam. Table 3.2 makes it even clearer: among those who were still in school $51.1 \%$ of descendants of Turkish migrants in Amsterdam reported working and studying in comparison to $21.1 \%$ of the students with a Turkish background in Strasbourg. This points to a stark contrast between the two settings.

Table 3.1 Respondents' current activity

\begin{tabular}{l|l|l|l|l|l|l}
\hline & \multicolumn{3}{|c|}{$\begin{array}{l}\text { Descendants of immigrants from } \\
\text { Turkey in Amsterdam }\end{array}$} & \multicolumn{3}{l}{$\begin{array}{l}\text { Descendants of immigrants from } \\
\text { Turkey in }\end{array}$} \\
\cline { 2 - 7 } & Male & Female & Total & Male & Female & Total \\
\hline Working & $44 \%$ & $32.8 \%$ & $38 \%$ & $59.8 \%$ & $39.4 \%$ & $47.2 \%$ \\
\hline Work and study & $\mathbf{2 2 \%}$ & $\mathbf{1 6 . 4 \%}$ & $\mathbf{1 9 \%}$ & $\mathbf{6 . 2 \%}$ & $\mathbf{6 . 5 \%}$ & $\mathbf{6 . 3 \%}$ \\
\hline $\begin{array}{l}\text { Apprenticeship/ } \\
\text { internship }\end{array}$ & $\mathbf{4 . 6 \%}$ & $\mathbf{8 . 6 \%}$ & $\mathbf{6 . 8 \%}$ & $\mathbf{1 \%}$ & $\mathbf{0 . 6 \%}$ & $\mathbf{0 . 8 \%}$ \\
\hline $\begin{array}{l}\text { Inactive (sick or not } \\
\text { seeking work) }\end{array}$ & $4.6 \%$ & $4.7 \%$ & $4.6 \%$ & $4.1 \%$ & $2.6 \%$ & $3.2 \%$ \\
\hline Caring for children & 0 & $18 \%$ & $9.7 \%$ & $1 \%$ & $11 \%$ & $7.1 \%$ \\
\hline Unemployed & $9.2 \%$ & $11.7 \%$ & $10.5 \%$ & $9.3 \%$ & $14.2 \%$ & $12.3 \%$ \\
\hline Only studying & $\mathbf{1 5 . 6 \%}$ & $\mathbf{7 . 8 \%}$ & $\mathbf{1 1 . 4 \%}$ & $\mathbf{1 8 . 6 \%}$ & $\mathbf{2 5 . 8 \%}$ & $\mathbf{2 3 \%}$ \\
\hline Total (N) & 109 & 128 & 237 & 97 & 155 & 252 \\
\hline Sounc: & & & & & & \\
\hline
\end{tabular}

Source: TIES Survey 2008

Table 3.2 Participation in student employment at the time of the survey

\begin{tabular}{l|l|l|l|l|l|l}
\hline & \multicolumn{3}{|l|}{$\begin{array}{l}\text { Descendants of immigrants from } \\
\text { Turkey in Amsterdam }\end{array}$} & \multicolumn{3}{l}{$\begin{array}{l}\text { Descendants of immigrants from } \\
\text { Turkey in Strasbourg }\end{array}$} \\
\cline { 2 - 7 } & Male & Female & Total & Male & Female & Total \\
\hline Work and study & $52.2 \%$ & $50 \%$ & $51.1 \%$ & $24 \%$ & $19.6 \%$ & $21.1 \%$ \\
\hline $\begin{array}{l}\text { Apprentice/ } \\
\text { internship }\end{array}$ & $10.9 \%$ & $26.2 \%$ & $18.2 \%$ & $4 \%$ & $2 \%$ & $2.6 \%$ \\
\hline Only study & $37 \%$ & $23.8 \%$ & $30.7 \%$ & $72 \%$ & $78.4 \%$ & $76.3 \%$ \\
\hline Total (N) & 46 & 42 & 88 & 25 & 51 & 76 \\
\hline
\end{tabular}

Source: TIES Survey 2008 
Table 3.3 Qualitative profiles for work and study

\begin{tabular}{l|l|l|l|l|l|l|l}
\hline & \multicolumn{5}{l}{$\begin{array}{l}\text { Descendants of immigrants from } \\
\text { Turkey in Amsterdam }\end{array}$} & \multicolumn{4}{l}{$\begin{array}{l}\text { Descendants of immigrants from } \\
\text { Turkey in Strasbourg }\end{array}$} \\
\cline { 2 - 8 } & Male & Female & Total & Male & Female & Total \\
\hline $\begin{array}{l}\text { Regular (and irregular) } \\
\text { employment }\end{array}$ & 13 & 11 & 25 & 5 & 4 & 9 \\
\hline $\begin{array}{l}\text { Irregular employment } \\
\text { only }\end{array}$ & 0 & 0 & 0 & 6 & 3 & 10 \\
\hline $\begin{array}{l}\text { Didn't combine work } \\
\text { and study }\end{array}$ & 0 & 1 & 1 & 1 & 5 & 6 \\
\hline Total & 13 & 12 & 25 & 12 & 12 & 25 \\
\hline
\end{tabular}

Source: Qualitative interviews

Even though it has no statistical representation, the study's qualitative data showed a similar trend. The qualitative fieldwork included 25 interviews with students in Amsterdam and 25 in Strasbourg, discussing their education-to-work transition processes. The interviews revealed that student employment is a significant experience for young people and information was gathered on the students' employment histories, circumstances under which they sought work, and their reflections on their employment experiences. In Table 3.3, student employment activities are summarized with regard to my respondents' past and current experiences. "Regular and irregular employment" refers to situations in which students worked on a regular basis during the course of their schooling for at least a period. The same respondents might also have worked irregularly at some point, but they remain in this category. "Irregular Employment only" refers to cases in which students worked only in irregular jobs during summer breaks or holidays or at short intervals during vacations, but never regularly during their course of studies. This distinction is intended to highlight the regular nature of student employment, especially in Amsterdam.

As in the findings from the TIES survey samples, work-study practices were found to be more common in Amsterdam. Since the qualitative interviews were able to account for occupational histories, we obtained more detailed information on student employment in Strasbourg. In Amsterdam, almost all the respondents had a job throughout their studies, except for one person who dropped out of school after lower secondary education (VMBO) hence could not combine work with study and started working immediately. In Strasbourg, more than half of the surveyed youths combined work and study, though female respondents held part-time jobs less frequently. In contrast to Amsterdam, there was also more variation in work-study combinations in Strasbourg, with a mix of regular and irregular employment, or no employment at all.

Table 3.4 presents characteristics and regularity of the student jobs in the TIES data. Full-time jobs are defined as being 32 or more hours per week, versus parttime jobs, which are 31 or fewer hours per week.

In Amsterdam, most of the TIES survey respondents worked in part-time jobs with temporary contracts. However, their jobs appear quite stable as most reported 
Table 3.4 Nature of student employment

\begin{tabular}{|c|c|c|c|c|c|c|}
\hline & \multicolumn{3}{|c|}{$\begin{array}{l}\text { Descendants of immigrants from } \\
\text { Turkey in Amsterdam }\end{array}$} & \multicolumn{3}{|c|}{$\begin{array}{l}\text { Descendants of immigrants from } \\
\text { Turkey in Strasbourg }\end{array}$} \\
\hline & Male & Female & Total & Male & Female & Total \\
\hline $\begin{array}{l}\text { Full time work } \\
\text { (vs. part time work) }\end{array}$ & $\begin{array}{l}12 \% \\
(88 \%)\end{array}$ & $\begin{array}{l}19 \% \\
(81 \%)\end{array}$ & $\begin{array}{l}15 \% \\
(85 \%)\end{array}$ & $\begin{array}{l}67 \% \\
(33 \%)\end{array}$ & $\begin{array}{l}40 \% \\
(60 \%)\end{array}$ & $\begin{array}{l}50 \% \\
(50 \%)\end{array}$ \\
\hline $\begin{array}{l}\text { Fixed contract } \\
\text { (vs. other types) }\end{array}$ & $\begin{array}{l}33 \% \\
(67 \%)\end{array}$ & $\begin{array}{l}33 \% \\
(67 \%)\end{array}$ & $\begin{array}{l}33 \% \\
(67 \%)\end{array}$ & $\begin{array}{l}50 \% \\
(50 \%)\end{array}$ & $\begin{array}{l}20 \% \\
(80 \%)\end{array}$ & $\begin{array}{l}31 \% \\
(69 \%)\end{array}$ \\
\hline $\begin{array}{l}\text { Worked at firm for } \\
1 \text { year or more } \\
\text { (vs. less than } 1 \text { year) }\end{array}$ & $\begin{array}{l}62 \% \\
(38 \%)\end{array}$ & $\begin{array}{l}52 \% \\
(48 \%)\end{array}$ & $\begin{array}{l}60 \% \\
(40 \%)\end{array}$ & $\begin{array}{l}17 \% \\
(83 \%)\end{array}$ & $\begin{array}{l}20 \% \\
(80 \%)\end{array}$ & $\begin{array}{l}18 \% \\
(82 \%)\end{array}$ \\
\hline Total $(\mathrm{N})$ & 24 & 21 & 45 & 6 & 10 & 16 \\
\hline Mean age & 21.6 & 22.4 & 22 & 21.5 & 21.8 & 21.6 \\
\hline
\end{tabular}

Source: TIES Survey 2008

working in the same place for more than 1 year. Conversely, only a minority of the students in Strasbourg reported having worked at their job for longer than 1 year. That said, the case numbers are too low in Strasbourg to allow for a robust analysis.

In Amsterdam, most of the TIES survey participants found work in financial intermediation services and the wholesale/retail sectors, followed by hotels and restaurants. In Strasbourg, the majority worked in the wholesale and retail sector, followed by financial and healthcare services. In Amsterdam TIES data, friends and family provided access to student employment for most of the survey participants. In Strasbourg TIES data, most students used job agencies to find work, followed by their social contacts as the second most common resource. Reverting back to qualitative data, similar trends were observed with the interview respondents. Among the 25 interviewees the most popular areas of employment in Amsterdam were the retail sector-mostly in supermarkets, but also as assistants or sales advisors-and the airline industry — cleaning airplanes or working in the baggage section. There is also a notable gender division in these employment practices: airport jobs, which are physically demanding but easily accessible and well-paid, are mostly taken by males. While the majority of Amsterdam students worked in low-status jobs, some held positions that were related to their area of study — such as banking-and were expected to improve their CVs. Most jobs in Amsterdam were arranged around school hours during the week. Young people were flexible with their working schedules, and working hours ranged from 12 to 24 or more per week, with some considering full-time work during the short school vacations or over the summer. Furthermore, some participants had rather stable employment; they worked for the same employer for 2.5 years, and switched between full-time and part-time work throughout their studies. The respondents in Amsterdam mostly used their social contacts to find jobs, in addition to employment agencies (uitzendbureaus) and online advertisements. They became increasingly acquainted with certain jobs, especially those in supermarkets and airports, so they would turn to these jobs in periods of unemployment. 
Table 3.5 Sources of students' income

\begin{tabular}{l|l|l}
\hline & $\begin{array}{l}\text { Descendants of immigrants from } \\
\text { Turkey in Amsterdam }\end{array}$ & $\begin{array}{l}\text { Descendants of immigrants from } \\
\text { Turkey in Strasbourg }\end{array}$ \\
\hline $\begin{array}{l}\text { Grants and work and } \\
\text { study }\end{array}$ & $23.9 \%$ & $5.3 \%$ \\
\hline $\begin{array}{l}\text { Only work and study (no } \\
\text { scholarship) }\end{array}$ & $27.2 \%$ & $15.8 \%$ \\
\hline $\begin{array}{l}\text { Only scholarship (no } \\
\text { work and study) }\end{array}$ & $31.9 \%$ & $34.2 \%$ \\
\hline $\begin{array}{l}\text { No source of income } \\
\text { reported }\end{array}$ & $17 \%$ & $44.7 \%$ \\
\hline Total (N) & 88 & 76 \\
\hline
\end{tabular}

Source: TIES Survey 2008

In the case of the Strasbourg group, there were three main areas of employment: in the construction sector, in factories working in assembly lines, and in janitorial jobs (mostly in the Parliament). There were also smaller side jobs, such as newspaper distribution or babysitting. Another activity was doing unpaid work in the family business. In Strasbourg, many of the part-time jobs were during the summer or school vacations. However, those who were regularly employed had to work during the weekends. No respondents worked in the same place for more than 1 year, although some may have returned to the same summer job every year. Some of the Strasbourg respondents reported finding it particularly difficult to combine school with work as class attendance was obligatory and also very demanding. ${ }^{5}$ As in Amsterdam, most jobs, especially cleaning jobs, were found via social contacts. Other jobs, such as factory work and other short-term posts, were found through job agencies (office de l'intérim).

\subsubsection{Financial Motivations to Work in Amsterdam and Strasbourg}

Financial motivations are a significant impetus for student employment. The TIES survey provides information on the students' self-reported monthly income based on earnings from their part-time jobs and/or scholarships. Table 3.5 shows the distribution of income sources in both settings.

In Amsterdam, $83 \%$ of the sample reported having some sort of an income from either study grants student employment or both at the time of the survey. In addition, $34.4 \%$ reported having an income lower than $€ 550$ per month, while $44.4 \%$ of the students reported a higher income. However, in Strasbourg, only 55.3\% reported

\footnotetext{
${ }^{5}$ The level of difficulty depended on the type of study. While official hours of study do not differ greatly between the Netherlands and France, in practice higher education seems to require more class attendance in France while allowing for more autonomy in Amsterdam.
} 
Table 3.6 Activity among grant-receiving and non-grant receiving students

\begin{tabular}{l|l|l|l|l}
\hline \multirow{2}{*}{} & \multicolumn{3}{|l|}{$\begin{array}{l}\text { Descendants of immigrants from Turkey } \\
\text { in Amsterdam }\end{array}$} & $\begin{array}{l}\text { Descendants of immigrants from } \\
\text { Turkey in Strasbourg }\end{array}$ \\
\cline { 2 - 5 } & No study grant & $\begin{array}{l}\text { Received study } \\
\text { grant }\end{array}$ & No study grant & $\begin{array}{l}\text { Received study } \\
\text { grant }\end{array}$ \\
\hline $\begin{array}{l}\text { Work and } \\
\text { study }\end{array}$ & $61.5 \%$ & $42.9 \%$ & $26.1 \%$ & $13.3 \%$ \\
\hline Stage & $20.5 \%$ & $16.3 \%$ & $4.3 \%$ & $0 \%$ \\
\hline $\begin{array}{l}\text { Only } \\
\text { studying }\end{array}$ & $17.9 \%$ & $40.8 \%$ & $69.6 \%$ & $86.7 \%$ \\
\hline Total (N) & 39 & 49 & 46 & 30 \\
\hline
\end{tabular}

Source: TIES Survey 2008

having a regular income, while $44.7 \%$ had no source of income from scholarships or jobs at the time of the interview. One fourth of the students stated that they had a monthly net income of less than $€ 550$, while only $9 \%$ reported having an income of more than $€ 550$ per month.

In Amsterdam, income from grants, student employment or both was considerable, while in Strasbourg, most students seemed to be dependent on family support. This descriptive finding from the TIES survey becomes more amplified with the qualitative interviews below, where the (especially male) respondents in Strasbourg were more financially dependent on their family and felt pressure to quickly enter the labour market and drop out of education. In Amsterdam, however, similar financial pressures were eased by part-time student employment.

We also observed a relationship between receiving a grant and having a student job. In Amsterdam, 55.7\% of the sample stated that they had received some sort of study grant. Table 3.6 shows the activity distribution of those in receipt of grants compared to those who did not in both Amsterdam and Strasbourg. The table illustrates that students who did not receive a scholarship were more active in workstudy situations in both settings.

For the children of Turkish immigrants in Amsterdam there is a significant association between work-study practices and whether or not the student was receiving a study grant. Students without a grant were three times more likely to combine work and study than those who do. ${ }^{6}$ In Strasbourg, the association between workstudy combination and receipt of a grant was not significant according to a Pearson's chi-square test. Using odds-ratios, we can see that those who do not receive a grant are 2.4 times more likely to combine work and study compared to those who do.

Regarding parental financial support, parents' occupational activity was used as a proxy as the TIES Survey did not provide information on the parental household income.

Table 3.7 illustrates patterns of employment among the parents of the respondents who were still studying at the time of the survey. While there is no information on their parents' income level, $31.8 \%$ of the respondents reported that their fathers

${ }^{6}$ Pearson's chi-square was significant: $x 2(1)=5.17 \%, p<0.05$. 
Table 3.7 Students' Parents' occupation

\begin{tabular}{l|l|l|l|l}
\hline & \multicolumn{2}{|l|}{$\begin{array}{l}\text { Descendants of immigrants from } \\
\text { Turkey in Amsterdam }\end{array}$} & \multicolumn{2}{l}{$\begin{array}{l}\text { Descendants of immigrants from } \\
\text { Turkey in Strasbourg }\end{array}$} \\
\cline { 2 - 5 } & Father & Mother & Father & Mother \\
\hline Working & $43.2 \%$ & $30.6 \%$ & $75 \%$ & $44.7 \%$ \\
\hline Seeking work & $2.3 \%$ & $3 \%$ & $3.9 \%$ & $9.2 \%$ \\
\hline $\begin{array}{l}\text { Sick or otherwise } \\
\text { inactive }\end{array}$ & $31.8 \%$ & $27.3 \%$ & $9.2 \%$ & $3.9 \%$ \\
\hline Retired & $6.8 \%$ & $2.3 \%$ & $6.6 \%$ & $1.3 \%$ \\
\hline Caring for children & $0 \%$ & $29.5 \%$ & $0 \%$ & $39.5 \%$ \\
\hline Missing/DK & $15.9 \%$ & $6.8 \%$ & $5.2 \%$ & $1.3 \%$ \\
\hline
\end{tabular}

Source: TIES Survey 2008

were inactive or on sick leave compared to $9.2 \%$ in Strasbourg. Hence in Amsterdam only $55 \%$ of the sample had at least one employed parent, whereas $45 \%$ reported both parents as being inactive or unemployed. In Strasbourg, however, 85\% of students had at least one parent active in the labour market. The differences in parental activities are in line with previous literature. In Amsterdam there has been a sharp decrease in the employment of Turkish first-generation migrants since the 1990s due to the closure of the garment industry and the remaining manufacturing business (Rath 2002; CBS 2004). In France, even though members of the Turkish first generation were more likely to be unemployed than native-born French, their activity rates were higher than those in Amsterdam as 2/3 of the Turkish migrants reported being active (Perrin-Haynes 2008). We found no significant association between parental activity and the students' work-study combination. However, concentrating on the odds-ratios reveals that, in Strasbourg, native-born descendants of Turkish immigrants with two inactive parents are 2.6 times more likely to combine work and study compared to those who had at least one active parent. In Amsterdam, those with two inactive parents are only 1.2 times more likely to combine work and study than those with at least one employed parent. As a result, students in Strasbourg whose parents were not active in the labour market are more likely to combine work with study than students in Amsterdam.

All in all, despite the limitations of the TIES survey data, the descriptive analysis reveals striking differences between the settings. Respondents in Amsterdam combined work and study more often and reported wider access to scholarships compared to the respondents in Strasbourg. We can argue that not having other means to support their studies, respondents in Strasbourg were more dependent on parental support. This was also reflected in the relationship between parental activity and the likelihood of working and studying: those with inactive parents were more likely to work compared to their counterparts in Amsterdam. The qualitative interviews below shed more light on this distinction between the two settings.

For the respondents in the qualitative interviews, financial reasons also formed the major impetus for student employment among respondents. In Amsterdam, all 
respondents resided in the same household as their parents during their studies. ${ }^{7}$ Most students received a student finance grant called studie financiering, ranging from $€ 100$ to $€ 500$ per month depending on their parents' income and place of residence. However, the students stressed that these grants did not cover all of their expenses, but just supplemented their income. Soner, a final-year student in postsecondary vocational education (MBO) studying commerce (Handel in Dutch), was working in a phone store at the time of the interview. He had always had stable part-time employment since the age of 16 . He had worked for at least 2 years in each of his jobs. His main motivation for changing employment was higher pay. He stated that scholarship funds only covered some of his primary needs, and that he had to work to supplement them:

INTERVIEWER: What do your parents do?

SONER: My dad works. My mum sometimes [works]; once or twice a week if necessary. Now I get studie (study aid), but there's nothing left after tuition, health insurance and the phone bill. So I have to work. I mean, you have to work; there is nothing left. It is expensive here you know.

Even among students with low-income parents, the family's financial situation was not mentioned as providing "an obligation to work." The objective conditions-in this case the parents' financial standing and the scarceness of study grants-led more students to see part-time work as the most "reasonable" activity (Bourdieu 1977, p. 77). Irrespective of their parents' financial position, the earnings from these part-time jobs did not contribute to household income. This income was for the respondents to pay for their personal expenses such as school fees or consumer goods. Gül, a final-year HBO student at a tertiary vocational school, had had an intensive student employment career since the age of 16 . She mentioned that she had a considerable income, and that she mainly spent it on clothes. While she didn't share her income with her parents, she also did not ask them for money.

GÜL: First I worked in a store. When I was 16 I think I worked for two years there or something, but, while I was working there, I found my other job. I have always done two jobs at a time. I can't get enough money, you know, that's what my mother says. My closet is always full. (giggles)

INTERVIEWER: How many hours per week would you work?

GÜL: I became greedy with money; I worked a lot! First in Blocker and also in the phone company. I was working every single day. I had quite a good salary at the end of the month.

Increased consumption was both an important outcome and a major motivator of student employment among my respondents. Previous research on youth sociology has shown how participation in the consumer economy has become an integral part of young people's lives, and is even considered as one way of becoming an adult (du Bois-Reymond 2009b). As Best argues (Best 2009), young people purchase and use goods in the consumer market to construct certain identities and to set themselves apart from their parents. Şakir, who dropped out of post-secondary vocational

\footnotetext{
${ }^{7}$ Those who lived with their parents only considered leaving home after getting married. Some students even continued to live with their parents or in-laws after marriage due to difficulties finding social housing or affordable childcare.
} 
education (MBO), works as a security guard and lives with his parents. He began working at the airport when he was 16 , and had been quite stably employed there for 4 years before becoming a security guard. Asked about his current income and whether he thought it was sufficient, he responded as follows:

ŞAKIR: Something happened here, how should I say? My parents are different, my parents do not get dressed up, they do not go out like I do. They are second generation and I am third generation, and there is a huge difference between these two. Why? Because they [my parents] came here, they don't speak Dutch, they purchase only the cheapest things, they don't do certain things, they have to take care of us. They came under these circumstances with the idea of returning [to Turkey] someday. But we are not like that. I am born here. I grew up here. Hence I have to spend the rest of my life here. I take this into consideration when I make each of my steps; I think that I will live here for the rest of my life. I speak Dutch, English, and Turkish; I have learned things over time. There is a big difference between my parents and me. [There is] also [a difference] between my grandparents and my parents.

Şakir articulates his "lifestyle choices", in terms of how he dresses and spends his leisure time, as distinguishing him from his parents (Best 2009, p. 256). He uses this distinction to emphasize the difference in social standing that had developed ("something happened here") between himself-a member of the "third generation" _ - and his parents, who were second generation "immigrants", trying to sustain their families on a minimum income and dreaming of returning to Turkey. Born and raised in the Netherlands, Şakir set himself apart with regard to his qualifications, future prospects, and also his tastes. Student employment has thus provided native-born descendants of Turkish immigrants with purchasing power, and this consumerism has become an integral part of their lives.

All of these respondents lived in the same household as their parents and depended on them for shelter, food and services such as laundry and cleaning. However, by not taking money from their parents and paying for their own expenses, they were articulating a sense of "independence" and building "responsibility." This feeling of independence becomes vital during the transition process, when young people are deciding whether to enter the labour market or pursue their studies into higher education. Especially for vocational students, having financial independence from their parents relieves economic concerns that would otherwise create pressure to enter the labour market. Ufuk was a vocational student with low-income parents. He had been working at the airport since the age of 16 . He explained his future plans as follows:

INTERVIEWER: What is your next step?

UFUK: I am planning to attend HBO [tertiary vocational education]. Some say it's hard, but I want to try...

INTERVIEWER: Do you have to pay for that school?

\footnotetext{
${ }^{8}$ Şakir provides an alternative conceptualization of generations. He classifies his father, who arrived in the Netherlands after his grandfather, as second generation, and himself as third generation, born and raised here. According to statistical definitions, his father is classified as 1.5 generation while he is second generation. This shows how the definition of generations varies among respondents.
} 
UFUK: Well some, not much. I've looked into some websites and been to a few open days where they talk about the schools, you know. But money is not an issue, you know; if you work part time, you make money.

Although Ufuk's vocational diploma qualified him to enter the labour market, he didn't seem to be in a hurry and wanted to try tertiary education first. Similarly, Sencer decided to access higher tertiary education after his vocational training. He did not ask his family's permission as he was paying his own school expenses.

SENCER: I didn't really ask them you know. I am the one who pays for the school, for the books. I haven't asked my parents for money since I was sixteen you know. Of course, they were OK with what I did in the end.

In Strasbourg, by contrast, students under financial obligations could feel pressure from their parents to start working. As in Amsterdam, all of the respondents in Strasbourg lived with their parents during their studies. Only those in tertiary vocational education (BTS) or university were eligible for grants those in high school (bac) or vocational training (CAP/BEP) were not. As a result, only a minority of the Strasbourg respondents were receiving a grant. These grants ranged from $€ 150$ to $€ 430$ per month, depending on family income, the number of siblings attending school, and the distance between their family's residence and the institution.

The Strasbourg students reported that their grants did not to cover their expenses. Nevertheless, they expressed gratitude for this income rather than dissatisfaction, saying it was "better than nothing." Since both access to and the amount of these grants were very limited, the motivation to combine work and study was contingent on the financial support provided by their parents. Whereas financial support from one's family did not strongly influence the decision to work in Amsterdam, in Strasbourg it determined whether or not someone worked on a regular basis. As combining study with a regular job was quite demanding, only those who felt a financial obligation to work regularly chose to.

Behzat had high grades for his vocational diploma (BEP) and was advised to continue his studies. He went to high school and obtained his professional baccalauréat (bac pro.) before embarking on tertiary vocational training (BTS). His parents were not able to support him financially and he had to work to pay for his personal expenses:

Behzat: I used to work during the holidays-in factories for example - and this was where the problem began. When the semester started, these jobs called me back to work. At first, I went to work at weekends and to school on weekdays. Sometimes I would even work during two days of school. Then I would feel very tired. I had to work because my father and my mother are both retired. My brother and my sister got married and moved to their own homes. So I was the only child living with my parents, and I didn't want to be a burden on them. I wanted to make my own money. I was 18 back then. I didn't want to have to ask my parents for money.

INTERVIEWER: How come?

Behzat: Because all my friends had already started working. But I hadn't. They paid for their own driving licenses. They had cars, but I didn't. I had also learned a trade and I told myself I could also make money and pay for my driver's license. I regret it. I wish I had finished my BTS (tertiary vocational diploma). It is getting very difficult to find a job without a BTS these days. 
Behzat had 5 days of intensive classes, which did not make it easy for him to combine work and study. He remembers that his father once asked him; "How long are you planning on studying?" Even though this was not an overt suggestion he quit school, all the conditions surrounding him suggested that entering the labour market was the right thing to do: his parents expected him to work, he already had a vocational degree, and all his friends were working. Today he regrets his decision: although he has a good job, he fears that should he become unemployed he will not find decent work again without a BTS degree. Behzat's case also points to the significance of gender roles and the male working-class culture that surrounds many of the male respondents. Although these youths are in favour of higher educationcontradicting theories of resistance among working-class males (Willis 1977) - it is not an easy goal to pursue given their circumstances. As illustrated in the previous chapter on education, most native-born descendants of immigrants from Turkey are advised to pursue vocational degrees (BEP/CAP), which do not provide direct access to higher education, and thus have to pursue a longer track to university. As they get older, these males need more money for their private expenses. Hence, for some, student employment becomes a necessity, especially if they want to stay in education. During lower secondary school (collège), Cengiz was a successful student but he was advised to take the vocational track, a decision he did not oppose. His parents were also supportive of his wish to take the vocational track since they wanted him to learn a trade. However, once in vocational education, he was advised to continue into higher education due to his good grades. His family already had a supermarket business, where he had been working after school until late at night. This situation became problematic when he began higher education;

CENGIZ: In my first year of professional lyceum, my parents already had the supermarket business. I was going there to work every day after school to help them. But it was too much. I was fed up. I said either I should drop out of school or quit the job, but I couldn't do both. Doing both, I was also unable to study properly. You could tell from my grades. At the vocational school (BEP), I had no difficulty; I never had to study. I was again working for my family, but it was easy. The vocational programme was so easy; I think it was even easier than secondary school (collège). It was the year I started the vocational school that my parents got the supermarket. I went there [to work] every night. We were all motivated by having our own business. We were comparing ourselves to others who had a supermarket and how much they were making. So I was working. It was also our pocket money. My dad said, "You can get whatever you want." But when things changed when I started high school.

INTERVIEWER: How did they change?

CENGIZ: The courses became more difficult because I was working so much. I finished the first year. I passed my classes but my grades were not that good. In vocational school my average was $15 / 20$ but in high school it went down to 10/20. My teachers said I should come the next year but I talked to my father and told him that I did not want to continue with school.

INTERVIEWER: How did he react?

CENGIZ: Look, I had my trade; I had a profession. He only said, "Do as you like, but don't come and say it was because of me."

Cengiz was accustomed to working during vocational school, but everything changed once he started lyceum. The fact that he already had a "trade" created a 
psychological safety net that allowed him to quit education. Yet, having dropped out, Cengiz neither worked in the family business nor in the area of his profession (plumbing); instead, he did all sorts of menial jobs, from delivery to factory assembly. Unlike Behzat, Cengiz did not express any regrets about his decision to drop out. He was only unhappy about his choice of trade, and he wished he had studied car mechanics instead of plumbing.

Conversely, while Deniz had also had to work regularly because of her family's financial difficulties, her job actually motivated her to obtain a degree:

DENIZ: I worked in factories and did cleaning jobs-maybe six or seven jobs like that over the course of my studies in high school and higher education. It was hard. Don't get me wrong, I did all those jobs willingly; in the end, I made money and I'm grateful. I never looked down on them; they taught me a lot. These jobs made me more dedicated to my studies; even today, they remind me how lucky I am to have my current job.

Unlike Behzat and Cengiz, Deniz had parents who were very supportive of her educational track despite their lack of affluence. Her father painted building exteriors as a profession and even worked extra hours to pay for private lessons to help her to catch up with her classes. Deniz felt responsible towards her father to make an income so as not to be a burden on her family.

In fact, as in Amsterdam, the majority of the Strasbourg respondents felt the need to work part time for their personal expenses, yet none used their earnings to contribute to their family's income. These earnings were their own; to pay for their consumer needs or living expenses and gain a sense of responsibility.

The second group of students were those who had no obligation to work due to their family conditions, but still wanted to earn towards their personal or living expenses. They worked during holidays or summer breaks to earn pocket money for their visits to Turkey or for purchasing consumer goods. Veli, a university student, worked all summer to earn spending money for the rest of the year:

VELI: I always worked in the summers. I would work with my father and my uncle on the construction site. I also worked in a restaurant. I would earn my pocket money because I didn't always study here. I studied outside [of Strasbourg] for three years; two years in Lille and one year in Nancy. I tried to earn at least the cost of my gas bill by working in the summer.

INTERVIEWER: How long would you work for?

VELI: About a month, I would say. I had holidays for one month.

INTERVIEWER: What do you think about your experience?

VELI: Not much. I just earned some money; nothing more than that.

Financial motivations are the main trigger for student employment among the majority of native-born descendants of immigrants from Turkey, both in Amsterdam and Strasbourg. Even if their family is low on funds and student grants don't cover their expenses, students can still engage in a consumer lifestyle and establish a sense of responsibility and independence while living at home thanks to their part-time, temporary jobs. The striking difference between the two settings was that while it was rather easy for students in Amsterdam to combine regular employment with studying, in Strasbourg it was difficult for students to combine both activities on a 
regular basis. In Strasbourg, regular work and study combinations posed a risk to students' educational trajectories and those who worked regularly during their studies struggled to stay in education. Especially male respondents felt more pressured to work and ended up dropping out of school due to their working activities. On the contrary, in Amsterdam, student employment practices eased the immediate financial pressure to start working and this enabled them to experience rather extended and flexible transition processes, in which they either alternated work and study or did both. We can even say that for some students, working part time enabled them to prolong their studies into higher education, though whether they succeeded in obtaining a diploma was uncertain at the time of the interview.

\subsubsection{The Role of Family Support and Students' Educational Capital in Choice of Part-Time Jobs in Amsterdam and Strasbourg}

Even though financial motivations were the main trigger for the majority of the respondents to combine work and study, some experienced and benefitted from student employment in a different manner. Previous research demonstrates that higher education students are more likely to combine work and study, as are older students (Lucassen 2003). The TIES survey shows similar patterns. In the TIES sample, the majority of the students who combined work and study were in higher education. Nevertheless, there was no significant association between being in higher education and combining work and study than being in vocational or higher secondary school and doing so. In this section I will study a trend which was made visible by the qualitative data as the TIES survey was cross-sectional and it was not possible to discern the influence of student employment on future transitions. When asking retrospective questions in the qualitative interviews, it became evident that some respondents also turned their student jobs into future social capital and work-related knowledge for finding jobs. This was striking among those with higher educational achievements and whose parents provided financial support since they were likely to choose jobs related to their studies and tended to see their work experience as an important credential for the labour market. Clearly, a socioeconomic differentiation has developed among the immigrant parents from Turkey since their arrival in the 1970s, as some have accumulated more financial, social and educational capital during their stay in the host country. Student employment practices within and across settings make it evident that some have accrued certain advantages. Students who could rely on their parents' financial capital said that their fathers not only paid for their school costs, but also for their consumer needs. This allowed them to focus on finding student jobs that would ultimately provide important credentials for entering the labour market, such as developing social capital or work-related information capital. Melek, a third year vocational tertiary education (HBO) student studying 
Business \& Economics reported that her parents covered all of her expenses. When asked about her student employment experiences, she said she had never worked in any menial job, such as a supermarket, but had instead applied for jobs related to her field of study:

INTERVIEWER: What are the most important elements when you are looking for a job after graduation?

MELEK: Qualifications, self-confidence, but also work experience. I think work experience is the most important. [Employers] still expect you to have done a part-time job in addition your studies. They expect that. If you have that experience, you receive priority [in the hiring process]. In order to minimize the risks of unemployment, I am trying to fill in my $\mathrm{CV}$ with experience at good companies.

INTERVIEWER: How?

MELEK: Via internships and student employment. For example, in my second year, even though it was very difficult, I still worked. Because I thought that, in this way, I could find an internship a lot more easily the next year.

At the beginning of her second year, Melek started looking for a job related to her studies through an employment agency website. She managed to arrange a part-time job (16 h per week) in a prestigious international audit company, $\mathrm{PwC}$ - a name she was unfamiliar with before her job search. She claims that it was only through people's reactions to the name that she understood how good a company it was and believes that this part-time job improved her chances of finding a good internship in her third year. For Melek, as a self-described "allochtone girl wearing a headscarf", these experiences were vital to improving her future chances in the labour market. ${ }^{9}$ First of all, Melek made business contacts by working in this company, which helped her to accrue job-related social capital. Furthermore, seeing other headscarfwearing women working in such a prestigious company helped build her selfconfidence about working in a similar environment in the near future. Having the name of such a firm on her CV clearly functions as symbolic capital for future employers.

Similarly, Bulut's parents covered her expenses and mobilized every family resource to assist her studies. She had just finished her MA degree after completing a HBO degree in Business \& Economics. Bulut was concentrating on internships and part-time jobs in the area of her studies. She highlighted what we may call symbolic capital with regard to the symbolic importance of "where one works" rather than "what one does" and how these positions were not only significant for her CV but also for providing crucial social capital for her future transition. These examples show how in the presence of parental support, combining work with studying could help young people to build forms of capital.

However, not all respondents with more financial resources worked in careerrelevant student jobs, while some from less affluent backgrounds did. Some MBO students conducted dual training, combining 4 days of work with 1 day of study.

\footnotetext{
9 "Allochtone" is a pejorative term used in the Netherlands to refer to ethnic minorities. However, it is important to underline that this terminology is being used by the respondents themselves to express their fears about how discrimination and stereotyping in the labour market might make it hard for them to find a position.
} 
Others transformed their internships into part-time employment or vice versa. For example, Nevin was a MBO student who found her scholarship grant too meagre and wanted to combine her studies with part-time employment. She was not happy with her job in a wholesale store because it was too strenuous for her. She managed to gain a position 4 days a week at the company where she had done her internship, going to school just 1 day a week. Nevin claimed to have enjoyed work more than school, and didn't mind finishing MBO in 3 years rather than two. In Amsterdam, most respondents were very conscious of the need to build and invest in their CVs. The major difference between higher education students working in their area of study (i.e. Melek and Bulut) and vocational students (i.e. Nevin and Hakan) was that the first group was more aware of the "symbolic value" of company names or social capital that would make it easier to get a good job after graduation. Higher education students were also more concerned about developing symbolic social capital for their future careers as they could not access any such contacts via their parents. When this knowledge is supplemented by family financial capital as well as emotional capital for their future mobility, young people are more easily able to access the kind of part-time work that is directly aligned with their studies, usually resulting in a more desirable job upon graduation.

In Strasbourg, none of the respondents had student jobs in their area of study. However, this might have been a sampling issue rather than a structural constraint as previous research has underlined that students with parents in managerial positions generally had study-related jobs and experienced smoother transitions to the labour market (Béduwé and Giret 2004).

Nevertheless, some respondents were inclined to undertake institutional workstudy combinations in the form of dual training to be able to work in their area of study. This is different from the examples in Amsterdam in that those in Amsterdam arranged part-time jobs next to their studies while those in Strasbourg looked for a job as part of their studies. This sort of combination was mostly utilized for tertiary vocational training (BTS), especially if students were attending a private institution. "Dual training" in BTS (BTS en alternance) involves 4 days of work and 1 day of study per week. It requires young people to find an employer who is willing to hire them and pay for their schooling in return for low-cost employment and tax reductions. However, it is difficult to find companies willing to commit to such an arrangement. Engin looked for a company where he could follow dual training for 2 years after receiving his high school diploma (bac tech.) because he wanted to combine his studies with a job in a related field. After sending more than 100 applications he eventually gave up on the idea and entered the labour market with only a high school diploma. By contrast, Selin managed to find a Turkish company willing to hire her thanks to her father's and uncle's extended networks. However, when this arrangement didn't work out and she had to change her employer, having had work experience made it easier for her to find another place where she could combine work and study for 2 years after high school. She later made a smooth transition to the labour market by staying with this second (French) company. Selin didn't have a student job or summer job at any point in her education as she had the full financial support of her family. Similarly, Gönül had to drop out of university due to a 
personal problem, but mobilized her family networks to find internships and an employer prepared to undertake a dual programme. Despite this help, Gönül's transition also didn't go smoothly. Her father arranged an internship in Germany with a Turkish employer, but this did not work out. After 1 year she was able to find another employer, this time of French origin, who was prepared to finance her dual training and she remained in this job after finishing her studies. As this example demonstrates, both their parents' financial and social capital and an individual's own educational capital are instrumental in facilitating employment or at least in gaining entry to the labour market. In both examples the parents provided some sort of entry despite their limited resources.

In both settings, those in higher education who had full financial support from their family were able to organize their student employment to their own career advantage. In Amsterdam, these students chose jobs which would have symbolic value in their resumes and would count as relevant work experience. Students in higher education were particularly aware of the importance of developing studyrelated work experience. This enabled them to develop social capital, symbolic capital and work-related information capital that they were unable to access via their families (as none of their parents were highly educated but rather operated successful businesses that allowed them to support their families financially). In Strasbourg, the respondents who were studying in a dual programme for vocational tertiary education (BTS en alternance), had to find an employer themselves before they could enrol in the programme. Hence parental connections and resources mattered. This is important as previous research in France has shown that those who worked in jobs in their area of study were more likely to make a successful transition to the labour market. This was also found to be the case among this study's respondents: those who were able to conduct a study-related dual study ended up staying in the same company once they graduated and therefore experienced very smooth transitions. Similar to Amsterdam, students who had graduated from tertiary education and were looking for a work in the highly-skilled professional labour market were unable to rely on parental resources.

\subsection{Conclusion: Implications of Work and Study Combinations}

Kasinitz and his colleagues (2008) have warned of the lack of attention currently paid to student employment among second-generation youth. Their data provided hints that student jobs could have a significant impact on the pathways of descendants of migrants as their migrant parents are unable to transmit much in the way of resources for either their education or their entry into the labour market. A meticulous study of student employment experiences among native-born descendants of migrants from Turkey shows the significance of this activity for their youth 
transitions. Furthermore the extent and nature of this influence differed across both settings. Both the quantitative and qualitative findings show that the young people in Amsterdam were more active in the labour market during their studies compared to their counterparts in Strasbourg, confirming existing trends in the Netherlands and France (Wolbers 2008). Such variation could not be attributed to labour market differences. In Amsterdam, state policies decreased scholarship access and individualized the cost of education for students via loans (Vossensteyn 1999, 2002). This was met with an increased labour market demand for low-skilled or unskilled labour and an increase in the value attributed to professional experience by the education system. This series of developments created a situation in which students, irrespective of parental financial capital, saw student employment as a "natural" activity. As well as facilitating consumerism, student employment provided a way for respondents to feel responsibility and independence while continuing to live with their parents (Best 2009). This financial independence played a pivotal role during the transition process: native-born descendants of immigrants from Turkey in Amsterdam felt less pressured by financial obligations to enter the world of work, and were thus able to extend their studies, enter tertiary education and experience rather more flexible transition processes. Financial pressures were most visible among male respondents: in both settings gendered motivations were observed among male respondents who felt more pushed to gain an income at an early age. Yet male respondents in Amsterdam managed this pressure by combining their studies with work and gaining a certain independence in their transition decisions.

In Strasbourg, state policies promoted student employment in order to pass on the costs of higher education (due to meagre scholarships opportunities) and also encouraged the professionalization of education by citing job experience as an important credential (OVE 2006). However, these policies were not yet wholly supported by the labour market and the school environments. The labour market was unable to provide flexible employment for students, offering rather precarious working conditions instead. Schools also enforced strict class attendance rules, making it hard for students to combine work and education without jeopardizing their studies. This created tension for students who wanted to pursue their education but did not have the means to do so, even more so if they did not receive sufficient grants. Furthermore, the lack of part-time employment opportunities often meant that leaving education and accessing the labour market were the only options for students with financial obligations.

The intention here is not to praise student employment opportunities. In fact, student employment proved to be both physically and mentally very demanding for many respondents and was often detrimental to their studies. In Strasbourg participating in student employment led to some respondents dropping out of education. Yet it needs to be underlined that the majority of the youngsters in this study, and also in general within the Turkish communities of Amsterdam and Strasbourg, grew up in poverty. These families, which often had many children, were seriously limited 
in their ability to offer financial support. Hence, student employment eased transition for respondents in Amsterdam from low-income families, enabling them to participate in a consumer lifestyle and gain a sense of financial independence without dropping out of education altogether. Our quantitative analysis showed that the 83\% of the sample reported having some sort of an income from part-time employment, scholarships or both. However, in Strasbourg, family resources remained the main source of student income, as only 55\% of students reported having some sort of an income, mainly from grants. In both settings, those without a grant were more likely to participate in student employment, which put their educational participation at risk and created conditions that led many of them to drop out.

In addition to gaining financial independence and pursuing a consumer lifestyle, some respondents even managed to make considerable contributions to their future labour market careers. Student employment exposed young people to a work environment where they learnt general skills, such as managing working hours, dealing with colleagues and various other realities of employment that they had been unaware of as students. They developed social capital that proved instrumental to their labour market transitions. Nevertheless the beneficial nature of student employment varied, depending on the family's financial and social capital and the student's own education capital. Accessing a study-related job or doing dual training provided significant advantages for transitions from education to work. Working in such jobs and placements enabled students to develop both cultural and social capital in their area of study and made a positive contribution to their transition. Confirming the hypothesis of Kasinitz and his colleagues (2008), such capital development in one's social trajectory is crucial for young people who are not from privileged backgrounds.

\section{References}

Béduwé, C., \& Giret, J. F. (2004). Le travail en cours d'études a-t-il une valeur professionnelle? Économie et Statistique, 378-379, 55-83.

Bérail, M. L. (2007). Le Travail des Étudiants. Journal Officiel-Republique Francaise Avis Et Rapports Du Conseil Economique Et Social, 25.

Best, A. L. (2009). Young people and consumption. In A. Furlong (Ed.), Handbook of youth and young adulthood: New perspectives and agendas (pp. 255-262). London: Routledge.

Bourdieu, P. (1977). Outline of a theory of practice. Cambridge/New York: Cambridge University Press.

Brooks, R. (2006). Learning and work in the lives of young adults. International Journal of Lifelong Education, 25, 271-289.

CBS. (2004). Allochtonen in Nederland En Leefsituatie. Den Haag: CBS[Host].

CBS. (2012). Turkse Ingezetenen in Nederland 2011. Den Haag: Centraal Bureau Voor Statistics.

Cereq. (2001). Premiers Pas Dans La Vie Active De La Génération 1998. Paris: Cereq.

Cereq. (2007). Premiers Pas Dans La Vie Active De La Génération 2004. Paris: Cereq. 
Cereq. (2014). Quand l'école est finie.Premiers Pas Dans La Vie Active De La Génération 2013. Paris: Cereq.

Delsen, L., \& Poutsma, E. (2005). Labour market institutions and economic performance in the Netherlands. International Economic Journal, 19(2), 169-196.

$\mathrm{Du}$ Bois-Reymond, M. (2009a). Integrated transition policies for European young adults: Contradictions and solutions. In I. Schoon \& R. K. Silbereisen (Eds.), Transitions from school to work: Globalization, individualization, and patterns of diversity (pp. 331-352). New York: Cambridge University Press.

Du Bois-Reymond, M. (2009b). Models of navigation and life management. In A. Furlong (Ed.), Handbook of youth and young adulthood new perspectives and agendas (pp. 47-54). Oxon: Routledge.

Eurydice. (2007). The education system in the Netherlands 2007. The Hague: Ministry of Education, Culture and Science.

Eurydice. (2008). Organisation of the education system in France. Paris: Ministry of Education.

Jamet, S. (2006). Improving labour market performance in France. Paris: OECD.

Kasinitz, P., Mollenkopf, J. H., Waters, M. C., \& Holdaway, J. (2008). Inheriting the city. The children of immigrants come of age. New York: Russell Sage Foundation.

Lucassen, S. C. H. H. L. (2003). Bijbanen van onderwijsvolgende jeugd. CBS, Sociaal-economische Maandstatistiek, 2, 16-18.

McNeal, R. B., Jr. (1997). Are students being pulled out of high school? The effect of adolescent employment on dropping out. Sociology of Education, 70(1), 206-220.

Mueller, W., \& Gangl, M. (Eds.). (2003). Transitions from education to work in Europe: The integration of youth into EU labour markets. Oxford: England University Press.

OVE. (2006). Présentation Des Principaux Résultats De L'enquête Conditions De Vie Des Étudiants 2006 [Presentation of the principal results of the survey on students life conditions]. Paris: Observatoire De La Vie Étudiante.

Perrin-Haynes, J. (2008). Principal: L'activité Des Immigrés En 2007.

Pigeaud, R., Clarens, V. D., Paty, M., Balmer, L., \& Roussel, R. (2009). VET in Europe- Country report France. Cedefob.

Pinto, V. (2010). L'emploi Étudiant Et Les Inégalités Sociales Dans L'enseignement Supérieur. Actes De La Recherche En Sciences Sociales, 183, 58-71.

Powell, J. J., Coutrot, L., Graf, L., Bernhard, N., Kieffer, A., \& Solga, H. (2009). Comparing the relationship between vocational and higher education in Germany and France (No. SP I 2009506). WZB Discussion Paper.

Rath, J. (2002). A quintessential immigrant niche? The non-case of immigrants in the Dutch construction industry. Entrepreneurship \& Regional Development, 14(4), 355-372.

Riele, S. T., \& Siermann, C. (2007). Bijna Een Miljoen Mensen met Een Kleine Baan. Sociaaleconomische Trends. 2nd-quarter, 36-39.

Ruhm, C. J. (1997). Is high school employment consumption or investment? Journal of Labor Economics, 15(4), 735-776.

Schoon, I., \& Silbereisen, R. K. (Eds.). (2009). Transitions from school to work: Globalization, individualization, and patterns of diversity. New York: Cambridge University Press.

Van der Meer, P., \& Wielers, R. (2001). The increased labour market participation of Dutch students. Work, Employment and Society, 15(1), 055-071.

Visser, K. (2010). VET in Europe- Country report the Netherlands. CEDEFOB.

Vossensteyn, J. J. (1999). The financial situation of students in the Netherlands. European Journal of Education, 34(1), 59-68.

Vossensteyn, H. (2002). Shared interests, shared costs: Student contributions in Dutch higher education. Journal of Higher Education Policy and Management, 24(2), 145-154. 
Wauquiez, L. (2006). Les aides aux étudiants les conditions de vie étudiante: Comment relancer l'ascenseur social? Paris: La Documentation Française.

Willis, P. E. (1977). Learning to labor: How working class kids get working class jobs. Farnborough: Saxon House.

Wolbers, M. H. (2003). Combinaties van werken en leren onder jongeren in Europa. Tijdschrift voor Arbeidsvraagstukken, 19(1), 20-33.

Wolbers, M. H. J. (2008). Scholieren met een bijbaantje: de gevolgen voor hun schoolprestaties. Mens \& Maatschappij, 83(3), 239-257.

Wyn, J., \& Dwyer, P. (1999). New directions in research on youth in transition. Journal of Youth Studies, 2(1), 5-21.

Zdrojewski, S., Grelet, Y., \& Vallet, L.-A. (2008). Increasing employment instability in France? Young people's labor market entry and early career since the 1990s. In H. Blossfeld (Ed.), Young workers, globalization and the labor market: Comparing early working life in eleven countries (pp. 103-127). Cheltenham: Edward Elgar Publishing.

Open Access This chapter is licensed under the terms of the Creative Commons Attribution 4.0 International License (http://creativecommons.org/licenses/by/4.0/), which permits use, sharing, adaptation, distribution and reproduction in any medium or format, as long as you give appropriate credit to the original author(s) and the source, provide a link to the Creative Commons licence and indicate if changes were made.

The images or other third party material in this chapter are included in the chapter's Creative Commons licence, unless indicated otherwise in a credit line to the material. If material is not included in the chapter's Creative Commons licence and your intended use is not permitted by statutory regulation or exceeds the permitted use, you will need to obtain permission directly from the copyright holder. 


\section{Chapter 4 \\ Transition Decisions: Intersections of Social Class, Gender and Ethnicity}

\subsection{Introduction}

The pathways that young people pursue at the end of their educational trajectories reflect both the constraints produced by insecure labour market conditions and the pressure to invest in credentials that will enhance their personal "market value". On the one hand, young people feel the need to prolong their studies beyond their compulsory training (Furlong and Cartmel 1997). On the other hand, they also feel pressured to start working and to gain financial independence from their families. Some combine their studies with part-time work (see Chap. 3), while others choose to leave school altogether. Those who leave the education system without a diploma or with only minimum qualifications are at great risk of exclusion from the labour market (Wolbers et al. 2001). Furthermore, previous studies of youth transitions have shown that leaving education is not necessarily definitive, as young people might return to school or experience cyclical periods of employment, unemployment and training. This has been interpreted as demonstrating the complexity of youth transitions in society today (Wyn and Dwyer 1999). While the literature on youth transitions generally accepts the prolonged and increasingly complex nature of youth transitions (Furlong 2009), we need to scrutinize the factors underlying these processes in order to understand which individuals are able to prolong their transitions (and how), how they cope with complex transitions and what makes for a smooth (or rough) transition.

In this section I scrutinize school-to-work transitions in their full complexity, investigating the prolonged and complex nature of youth transitions. I study transition processes in detail, drawing on the experience of vocational and academic track students when leaving school. First, I will describe the institutional settings and structural conditions in both cities. Thus far, I have only discussed the education system (in terms of the initial stratification point), the labour market structure (in terms of student employment), and the structures for financial support for students 
and the impact that these have on young people's transition decisions. In this section, I will analyze the education systems, this time in terms of their relationship to the labour market, and provide an overview of the labour market structure in both settings. The empirical findings begin with descriptive results from the TIES Survey with regard to transition outcomes. This brief outline is followed by an extended qualitative analysis drawn from the in-depth interviews, which provide crucial insights into the mechanisms behind each transition decision.

The analysis shows that gendered values in the ethnic community and the resources (especially social capital) of young people in relation to their friends and family are significant in shaping both their ('subjective') motivations and their ('objective') conditions. Studying social trajectories in detail reveals how young people negotiate structural constraints when trying to achieve their objectives and how, during their transitions, they build different forms of capital in their trajectories across distinct institutional settings. While focusing on the critical decision made at the so-called 'transition point', this chapter contextualizes that decision in the light of the trajectories of young people discussed in the preceding chapters, to illustrate that transitions do not take place at a single point in time.

\subsection{Institutional Structures}

In this section, I will describe the institutional context of transition in Amsterdam and Strasbourg, concentrating on two structures: the education systems- the opportunities they offer to extend one's education- and labour market conditions when entering the labour market.

\subsubsection{Educational Credentials}

As discussed in Chap. 2, young people's educational trajectories shape both their chances on the labour market and their further study options. Hence, a student's placement in a vocational or an academic trajectory pre-conditions the conditions of their transition outcome. The characteristics and structure of the two trajectories differ between the two settings and offer different opportunities or constraints for those transitioning to the labour market or to further study.

Occupational specificity is an essential characteristic of the educational trajectory for labour market transition. Previous studies have argued that the degree of occupational specificity in education systems plays a vital role in facilitating a smooth incorporation into the labour market (Raffe 2003; Bol and Van De Werfhorst 2013). Occupational specificity is mainly discussed with respect to vocational training, as academic education is perceived to be more scientific and general. However, in higher education, and especially with the growing popularity of tertiary colleges, occupational specificity has also become a significant feature differentiating education systems. 
Dutch vocational training provides occupational skills that are recognized by employers (Mueller and Gangl 2003). This is also true for tertiary education at vocational colleges (HBO) where young people have intensive periods of internship and acquire specific skills in their area of their study. In France, school-based vocational training is more general, with shorter periods of internship (Maurice et al. 1986; Powell et al. 2009). Students have the opportunity to do apprenticeships in upper secondary education and acquire a CAP diploma. However, increasingly, school-based vocational training leading to a BEP diploma is deemed more prestigious as it provides access to professional lyceums and thus is also the gateway to higher education (Duru-Bellat and Kieffer 2008; Powell et al. 2009). In tertiary education, vocational colleges are well established and provide a BTS diploma, though they require only short internship periods compared to Dutch vocational colleges (HBO). An exception is a form of vocational college (BTS en alternance) where young people combine 2 days of training in school with 3 days of work with an employer who is prepared to pay their educational costs and provide them a minimal income (Eckert 2005). Eckert (2005) claims that this form of training has proved very efficient as it usually facilitates a smooth incorporation into the labour market with the same employer.

Previous studies have repeatedly shown that these structures have implications for the outcomes of young people's transitions (Andersen and Van de Werfhorst 2010; Mueller and Gangl 2003). Zdrojewski et al. (2008) argued that vocational graduates in France face a higher risk that employers will judge them on the basis of their diplomas rather than their skills. In the Netherlands, where there is greater skill transparency, those with vocational diplomas benefit from specific skills gained through vocational education, and those who drop out of vocational training without a diploma are very vulnerable when entering the labour market (Iannelli and Raffe 2007; Van der Velden and Wolbers 2006).

In Chap. 2, I showed that a pupil's educational trajectory also determines their further study options. While the pupils in the academic track in both settings can gain direct access to higher education institutions after acquiring a diploma, the higher education institution that they were able to attend depended on their initial trajectory. Increasing credentialism in both the Dutch and French labour markets, means that young graduates from vocational streams also feel that it is necessary to access higher education in order to secure a desirable position. Over the past few decades, it has become increasingly difficult for those leaving the educational system with just qualifications from secondary school to secure a higher occupational level (Wolbers et al. 2001). The availability of student finance and scholarships is another feature of education systems that strongly influences the transition into further study (or not), especially for disadvantaged youth. Financial concerns can create pressure on young people to pass up on further study opportunities or even to drop out of school. As previously discussed, both countries provide financial assistance to students in higher education. As empirical analysis will now show, these arrangements are crucial in shaping young people's decisions to access tertiary education or drop out of education before acquiring a diploma. 


\subsubsection{Labour Market Structure}

Since the beginning of the 1980s, the Dutch labour market has become more flexible as employment protection legislation has been weakened, redundancy procedures relaxed and part-time jobs increased in number (Delsen and Poutsma 2005). Youth unemployment in the Netherlands has been gradually decreasing over the past few years and had fallen to $7.4 \%$ by 2010 . While increased flexibility has had a significant effect on youth unemployment (Remery et al. 2002), it has also resulted in more precarious working conditions, especially among those with lower qualifications (de Vries and Wolbers 2005; Wolbers 2008). Less-qualified young people are now more likely to be offered a temporary contract in their first jobs, compared to graduates of tertiary education, who are more often offered permanent contracts (Wolbers 2008). Those on temporary contracts are more likely to fall back into unemployment, which shows that flexible arrangements often do not provide a 'stepping stone' into stable careers (ibid, p. 98).

France has also made efforts to increase labour market flexibility (Zdrojewski et al. 2008). However, changes in employment protection legislation have reinforced the insider-outsider divide: it is now easier for employers to hire young people, but also to fire them (Zdrojewski et al. 2008). The French government has adopted active labour market measures to reduce youth unemployment among 16-30 year-olds. These include subsidizing public sector employment, promoting training programmes in the private sector and reducing employment costs for private employers. Over this period, there has been a noticeable increase in those working on temporary contracts through employment agencies. As a result, recent studies have shown that the school-to-work transition has become smoother over the last decade. A comparative study by Wolbers (2003) found that young people in the Netherlands and in France are incorporated into the labour market at a similar pace despite differences in their unemployment rates.

Zdrojewski's (2011) analysis of the Generation Survey found that more than $50 \%$ of school leavers in France entered their first job within 3 months of leaving education. However, women and young people from a migrant background took longer to find their first job, and those with lower qualifications also suffered from longer unemployment periods than those with a tertiary qualification. In both countries temporary contracts are more prevalent than before and poorly educated graduates are more likely to work under a temporary contract than those with higher level qualifications. In terms of job stability, those with higher diplomas or vocational degrees are less likely to become unemployed after their first job, than those with lower or general educational qualifications. In both countries, it is more difficult for the descendants of immigrants to access employment. In the Netherlands, the descendants of immigrants from Morocco and Turkey find it more difficult to access high-status jobs than their peers with the same qualifications (Tesser and Dronkers 2007). Young people with immigrant parents are also more likely than the children of native-born parents to fall into unemployment after gaining their first significant job (ibid). Meurs et al. (2005) have shown that young people in France 
with immigrant parents find it more difficult to enter the labour market, even after controlling for qualifications. Brinbaum and Guégnard's (2011) analysis of the 2004 Generation Survey showed that descendants of immigrants from Turkey, the Maghreb and African countries in France, experience higher unemployment and less smooth transitions("access rapide emploi" p. 10) than children of natives and Portuguese immigrants, who fared better. They found a strong correlation between the social class background of these young people's parents and their children's educational and occupational trajectories.

This overview underlines that, in both countries, flexibility measures in the labour market have been instrumental in combating youth unemployment to some extent, but have also led to more precarious employment and careers, especially among those with lower educational attainment (Blossfeld 2008) and with migrant background. Even after controlling for their educational level, the descendants of immigrants seem to face greater disadvantages when entering the labour market (Brinbaum and Guégnard 2011, 2013; Tesser and Dronkers 2007).

The two cities that are the focus of study, Amsterdam and Strasbourg, both have unemployment rates that are lower than the respective national averages. From 2003 to 2006, the unemployment rate in Amsterdam was $7.9 \%$ among men and $6.5 \%$ among women. According to Eurostat (2010) the male unemployment rate in Strasbourg from 1999 to 2002 was $9.4 \%$ and that for women $9.8 \%$. While the unemployment rate was higher in Strasbourg than in Amsterdam, both cities are relatively vibrant economic regions by their national standards. Amsterdam is a typical postindustrial economy, dominated by the service sector, followed by finance, health and care, media, ICT and knowledge (Nell and Rath 2009). This structure is reflected in the occupational choices of the interview respondents. In a recent study, Pasztor (2010) shows that business studies courses have become popular among native-born descendants of immigrants from Turkey as they offer better access to opportunities in the labour market. Services is also the largest sector in Strasbourg, followed by education, health and administration. While, the wider Alsace region is undergoing a transition to a post-industrial economy its manufacturing industry still provides many jobs. Both cities have sizeable populations of economically active immigrants from Turkey and their descendants. In Amsterdam there is entrepreneurship among members of this group, who often run small businesses such as snack bars, restaurants, grocery stores, and dry-cleaners (Kloosterman and Rath 2001). In Strasbourg, in addition to these establishments, the construction sector is a niche for immigrants from Turkey and their descendants, who predominate as both workers and as owners. By contrast, in the Netherlands, the construction sector has remained a protected niche for native-born groups (Rath 2002).

Thus, especially in Strasbourg, immigrant entrepreneurs from Turkey have established businesses that provide a source of employment, though mostly for low status jobs. Such jobs can be vital for descendants of immigrants, especially those who leave school early or with low level credentials. However, from the interviews it became clear that in both settings the descendants of immigrants from Turkey lack valuable contacts to secure positions in larger corporate sectors that require higher qualifications. 


\subsection{Making the Transition}

My analysis of transition processes from school to different activities focuses on four different groups of respondents. The first consists of early school leavers who dropped out of secondary education without a basic diploma. In Amsterdam, this group consists of those who dropped out of education before acquiring a MBO level two (n-2) certificate or HAVO or VWO diplomas. In Strasbourg, this group consists of those who left vocational training without a CAP or BEP diploma or lyceum without a baccalauréat diploma. The second group of respondents left education after successfully finishing vocational post- secondary education. The third group of respondents are those who left education after having received academic post-secondary diplomas such as baccalauréat in France or HAVO/VWO in the Netherlands. The fourth and last group of respondents went on to higher education (from either an academic or a vocational track), some acquiring a diploma, others not.

These four groups were defined on the basis of the institutionally designed trajectories determined by educational streaming. As discussed in Chap. 2, their transitions at the end of their education had largely been pre-conditioned by their initial transitions as a result of tracking. Yet their capital compositions also vary in the educational tracks they follow since differential tracking also instilled them with different types and forms of capital. These resources have an influence on their future trajectories: showing that young people are not necessarily limited by the forms of capital that they inherit from their parents, but also acquire them along their social trajectories in the academic or vocational tracks. In both Amsterdam and Strasbourg the institutional and educational structures influence young people's acquisition of different forms of capital.

\subsubsection{Educational Outcomes of School Leavers in TIES Survey}

Since the implementation of the 2007 Qualification Law, young people in the Netherlands are required to attain at least a basic qualification (startkwalificatie) in order to increase their chances of acquiring stable employment. This entails successfully completing 2 years of post-secondary vocational training (MBO n-2) or obtaining an academic or general-academic secondary school diploma (VWO or HAVO). Those who drop out before attaining these levels are called 'early school leavers'. The proportion of early school leavers has fallen to $9 \%$ in the last decade (CBS 2012), although this figure is higher among the children of immigrants (Kalmijn and Kraaykamp 2003).

In France, recent education reforms aim to ensure that $80 \%$ of students attain at least a baccalauréat, and have set a lyceum diploma as the minimum level. Those who cannot achieve this are encouraged to attain at least a vocational degree (CAP or BEP) (Mellottee et al. 2010). Recent studies in France have shown that young people with a vocational degree are more likely to secure employment than those who drop out of school after college (Duru-Bellat 2000). The chances of finding 
Table 4.1 Highest diploma attained among school leavers Strasbourg

\begin{tabular}{l|l|l|l|l|l|l}
\hline & \multicolumn{3}{|l}{ Strasbourg } \\
\cline { 2 - 8 } & \multicolumn{2}{l}{$\begin{array}{l}\text { Descendants of immigrants } \\
\text { from Turkey in Strasbourg }\end{array}$} & \multicolumn{4}{l}{ Comparison group } \\
\cline { 2 - 8 } & Male & Female & Total & Male & Female & Total \\
\hline $\begin{array}{l}\text { Lower secondary education } \\
\text { (College > out) }\end{array}$ & $25 \%$ & $31 \%$ & $28 \%$ & $4 \%$ & $4 \%$ & $4 \%$ \\
\hline $\begin{array}{l}\text { Vocational post-secondary education } \\
\text { (CAP/BEP > out) }\end{array}$ & $38 \%$ & $27 \%$ & $31 \%$ & $14 \%$ & $10 \%$ & $12 \%$ \\
\hline $\begin{array}{l}\text { Academic post-secondary education } \\
\text { (BAC > out) }\end{array}$ & $18 \%$ & $23 \%$ & $21 \%$ & $24 \%$ & $21 \%$ & $22 \%$ \\
\hline Tertiary education (BTS/Uni. > out) & $19 \%$ & $19 \%$ & $19 \%$ & $58 \%$ & $64 \%$ & $62 \%$ \\
\hline Total (N) & 72 & 104 & 176 & 50 & 67 & 116 \\
\hline
\end{tabular}

Source: TIES Survey 2008

Table 4.2 Highest diploma attained among school leavers in Amsterdam

\begin{tabular}{l|l|l|l|l|l|l}
\hline & \multicolumn{3}{l}{ Amsterdam } \\
\cline { 2 - 8 } & $\begin{array}{l}\text { Descendants of immigrants } \\
\text { from Turkey in Amsterdam }\end{array}$ & \multicolumn{4}{l}{ Comparison group } \\
\cline { 2 - 8 } & Male & Female & Total & Male & Female & Total \\
\hline $\begin{array}{l}\text { Lower secondary education } \\
\text { (VMBO-MBOn1 > out) }\end{array}$ & $44 \%$ & $34 \%$ & $38 \%$ & $10 \%$ & $8 \%$ & $9 \%$ \\
\hline $\begin{array}{l}\text { Vocational post-secondary education } \\
\text { (MBOn2-n3-n4) }\end{array}$ & $25 \%$ & $45 \%$ & $37 \%$ & $22 \%$ & $18 \%$ & $20 \%$ \\
\hline $\begin{array}{l}\text { Academic upper-secondary education } \\
\text { (HAVO/VWO) }\end{array}$ & $6 \%$ & $3 \%$ & $5 \%$ & $9 \%$ & $7 \%$ & $8 \%$ \\
\hline Tertiary education (HBO/Uni. > out) & $24 \%$ & $17 \%$ & $20 \%$ & $59 \%$ & $67 \%$ & $63 \%$ \\
\hline Total (N) & 63 & 86 & 149 & 91 & 92 & 183 \\
\hline Sorce TIES Survey 2008 & & & & & & \\
\hline
\end{tabular}

Source: TIES Survey 2008

employment in France are higher with each additional year of education (ibid). Table 4.1 shows educational attainments among school leavers in Strasbourg among this study's focus and control groups.

The TIES Survey shows that descendants of Turkish migrants, in both Amsterdam and Strasbourg, have lower levels of educational achievement than the comparison group. Table 4.1 illustrates the educational levels of those leaving education in Strasbourg. Twenty-five per cent of male respondents of Turkish origin and $31 \%$ of the females left school without attaining a diploma, whereas this figure was only $4 \%$ among the comparison group. Table 4.2 provides similar data for Amsterdam and reveals similar trends, although here the difference is even more startling. Fortyfour per cent of males and 34\% of females of Turkish origin left school without gaining the minimum qualification, in contrast to the comparison group of which just 9\% left education after VMBO. Early school leavers were highly represented among the qualitative sample. The following section provides detailed biographical interviews, showing show how their pathways led to them becoming early school leavers and how their transitions proceeded thereafter. 
The second large group consists of youngsters who left education with a vocational diploma. Table 4.1 shows that respondents of Turkish origin in Strasbourg more frequently acquire CAP/BEP than those with native-born parents $(31 \% \mathrm{com}$ pared to $12 \%$ ). In Amsterdam, 37\% of respondents of Turkish origin left education with a vocational diploma (MBO) in contrast to $20 \%$ of the control group. In both cities, Turkish second-generation groups are more likely to acquire vocational degrees than their peer group born to native parents. The in-depth interviews highlight how respondents from Amsterdam and Strasbourg in this group pursued different transition pathways and show that the vocational diploma in Amsterdam was of more value in the labour market than CAP/BEP diplomas in France, which, in the majority of cases, led to unskilled work.

The third group consists of survey participants who went on to academic lyceum (although not necessarily completing it). A striking difference between the two countries is the number of youngsters who left education after following an academic track at secondary school. In Strasbourg a substantial number of respondents - both descendants of migrants and the comparison group-did not go on to higher education. This group was much smaller in Amsterdam: $6 \%$ of the male descendants of Turkish migrants and $3 \%$ of the female descendants of Turkish migrants left education compared to $18 \%$ of the males and $23 \%$ of the females with Turkish origin in Strasbourg. This, as I will show later, was related to pupils in Amsterdam having higher expectations about the value of following tertiary education than their peers in Strasbourg. This was exacerbated by the more limited opportunities to combine higher education with work in Strasbourg, which pushed BAC diploma holders out of education and into the labour market.

When we look at those who acquired a diploma from tertiary education we find that descendants of migrants are significantly underrepresented in both cities: 19\% of the second-generation respondents in Amsterdam and 20\% of those in Strasbourg acquired a higher education degree, compared to $62 \%$ and $63 \%$ of the control group in Amsterdam and Strasbourg respectively. Yet, a higher education degree did not always guarantee high returns for descendants of migrants in the labour market, as I will discuss later.

In the next section. I will delve into how transitions in different educational trajectories evolved before and after leaving education.

\subsubsection{Transition Pathways: Insights from the Detailed Respondent Biographies}

\section{Early School Leavers}

The TIES data provides some information on the activities of early school leavers (see Fig. 4.1). This figure should be read with some caution as the sample size for the comparison group in both Amsterdam and Strasbourg was very small (See Tables 4.1 and 4.2, where there are only 4 respondents in total from the comparison group in Strasbourg). 


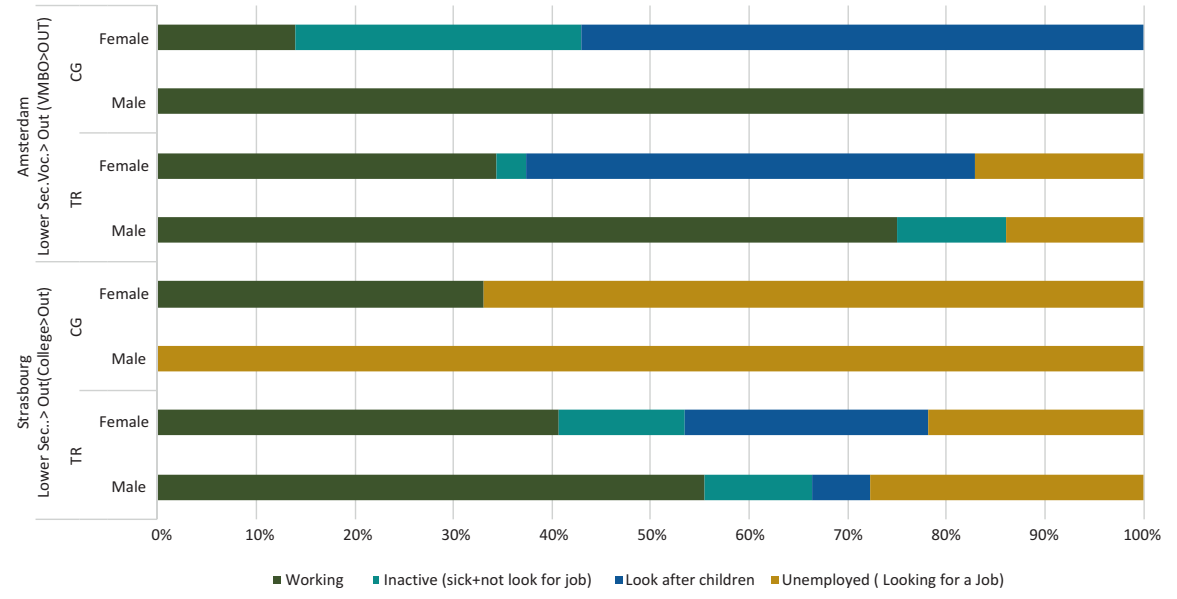

Fig. 4.1 Activity after school among early school leavers. (Source: TIES Survey 2008)

Unemployment levels among early school leavers were quite high in both Strasbourg and Amsterdam, which is not surprising considering that this is the most vulnerable group in the labour market. Figure 4.1 also shows that female respondents in both settings often reported looking after children as their main activity after leaving school. These trends are also discernible within the qualitative data, which I will use to illustrate the social trajectories of youngsters that lead to these outcomes.

The majority of those whom I interviewed in the qualitative fieldwork and who dropped out of school without a minimum qualification fell into low-skilled employment, both in Amsterdam and Strasbourg. Young men mostly opted for maledominated occupations that were physically demanding. In Amsterdam the most popular jobs were as cleaners or baggage handlers at Schiphol airport, or as security guards or taxi drivers. In Strasbourg, low and unskilled jobs were available in the construction sector or assembly lines in manufacturing. The young women in this group either worked in the catering industry or as cleaners, while most of them became homemakers, caring for children. Hence the transitions of early school leavers were gendered (Gaskell 1992) with male respondents under pressure to earn an income (as "breadwinners") and female respondents often getting married young and "looking after the household and children".

Below I will examine the transitional biographies of Şakir, and Defne, a male and a female respondent from Amsterdam. Although their biographies are not necessarily representative, they provide insights into how and why young people of Turkish descent end up leaving school early and how their pathways subsequently evolve. Their trajectories exemplify the gendered nature of transitions and the role of social capital in connecting (or disconnecting) young people with labour market opportunities. This will be followed by two biographies of females of Turkish descent from Strasbourg which, again, show how the respondents left school and how marriage provided a way out of their stagnant transitions. 


\section{Early School Leavers in Amsterdam}

Şakir, a male respondent from Amsterdam, dropped out of school without a vocational post-secondary education (MBO) diploma. His father arrived in the Netherlands in the later 1970s at the age of 18 together with his father and both worked in manufacturing. Şakir was born and raised in Amsterdam. He went to a local primary school, where he scored fairly well on the CITO exam. Despite this, he was advised to take the vocational track, which took him to one of most problematic secondary schools in Amsterdam, where there were issues of pupil criminality. After finishing lower secondary school (VMBO), he decided to do a technical course at a post-secondary vocational school (MBO) as he loved cars and wanted to start his own garage. However, Sakir came into conflict with his class mentor, whom he accused of being a 'racist', as he had suggested that no students with a Turkish background in his course would succeed. The conflict escalated and Şakir was expelled. He subsequently attended other training programmes, but he didn't persevere with them and eventually dropped out of school altogether.

ŞAKIR: First I went to do administration studies. I don't know any Turkish boy who studies administration in order to acquire an occupation; we all go there for the girls. So, you know, I didn't really pay much attention to my studies and soon dropped out. Then I decided to try an $\mathrm{MBO}$ in commerce. I thought I could manage that. But the class was full of Moroccans. And, you know, even since I was little, I have never been able to get along with Moroccans. So, once more, I got involved in a conflict and was eventually expelled. And that was it. I left school.

Even though Şakir acknowledged the importance of studying, and tried various institutions, he lacked a clear goal. In that sense neither Sakir nor any of the other respondents in my study, had a negative reaction towards education as was the case with Paul Willis's (1977) "working-class lads". These youngsters were more like Brown's (1987) “ordinary kids", working-class youngsters with limited resources, who recognized the importance of a diploma for obtaining a decent position on the labour market (Lehmann 2004, 2007). Nevertheless this kind of 'instrumental approach' towards schooling entails the risk that pupils will dropout if they do not perceive school as helping their employment prospects (Longwell-Grice 2003; Macleod 2009). This was the case with Şakir. Furthermore he had started working as a baggage handler at the airport at the age of 16 to pay for his personal expenses as his family had limited resources. So he already had a side-job when he embarked upon his car mechanic training. Each time he dropped out of a course, he could fall back on his student job, working on a full-time basis. Eventually he no longer saw the point in studying as he already had a job and had even been promoted to supervisor. But 2 years down the line, he had become disenchanted with his difficult working conditions, physical strain and lack of prospects. He often had conflicts with his colleagues, whom he defined as either "low-educated old guys or migrants with no other options". Şakir, in contrast, had been born in the Netherlands, spoke Dutch and felt he had more potential. Around this time one of his friends suggested that he find a job as a security guard. At first, he was not sure he could do this as he did not have a basic post-secondary vocational diploma (MBO n-2). His friend reassured him that, as a guard, "you don't do much". He applied and was accepted. 
Şakir expressed mixed feelings about this occupation, saying, "our job is not a job really; you basically do nothing." Yet he also argued that he is "his own boss", and that one actually needs to have social and language skills to be a successful security guard. He talked about how he chats with customers, employees and contributes to creating a pleasant environment in his workplace. At the time of the interview, he was working long hours, 7 days a week, in order to obtain a permanent contract and accrue some savings. He wanted to get married and dreamed of starting his own security company. He mentioned entrepreneurship as a career goal several times during the interview. When asked about returning to school, he stressed that, while this was always an option in the Netherlands, it was one that was closed to him. He suspected that the only drawback of not having a diploma was that it might make it more difficult to get a bank loan when starting his own business. The desire to start one's own company was a common ambition among all respondents, especially those without high hopes of occupational mobility, but also among those with higher qualifications, maybe because they had successful entrepreneurs in their family as role models.

Şakir's case provides an example of losing touch with school and finding an alternative route into the labour market through student jobs and social contacts. Like all male respondents, he felt pressured to earn an income which he did by finding a side-job. While he lacked educational capital as he had left vocational college (MBO) without a minimum diploma, his early exposure to work helped him to develop occupational skills that enabled him to 'market' himself well in interviews and on the shop floor. His connections with friends yielded instrumental social capital which helped him find his current occupation. These skills were developed throughout social trajectories and were not transmitted from his family.

Female respondents who left school without a diploma also ended up in lowskilled jobs. For them, marriage provided an alternative transition route. As Fig. 4.1 showed, looking after children is a common activity among female respondents. The cases of Defne in Amsterdam, and Ayla and Fatmagul in Strasbourg underline the role of marriage as a transition pathway. Defne's case also emphasizes the role that social capital and developing bridging ties with majority group can play in achieving mobility. Defne's mother came to Amsterdam as a child with her parents and married Defne's father, who was from her hometown. The marriage did not last, however, and they divorced just after Defne left lower secondary school (VMBO) at the age of 16. Torn between her parents, Defne decided that the best way to avoid this conflict and establish her independence was to get married. As she put it; "You know, we cannot live on our own or with a boyfriend. So I decided to get married." Since she was not dating anyone at the time, it was an arranged marriage. Her husband was from her parents' hometown in Turkey. She dropped out of school and went to Turkey to get married. However, legislation to discourage overseas marriages (CBS 2012) meant that Defne had to earn enough to support them both in order to bring her husband to the Netherlands. Together with her husband, she did various low-skilled jobs, with her husband mostly working 'black', until they were able to rent their own house and buy furniture. These jobs included working in factories outside Amsterdam, flower shops and as cleaners in the airport. 
Over time, her husband improved his language skills and started his own company with another relative, working as handymen. As soon as his company prospered, Defne took a break from her precarious jobs and became pregnant. After 2 years, her husband was able to acquire a mortgage from the bank to buy their own house. In the new neighbourhood, Defne met a Dutch neighbour, who used to work in a Bank and she told her about a vacancy at a Turkish bank for a desk clerk who could speak both Turkish and Dutch. Defne applied and got the job. She emphasized that she would never have been able to find an equivalent position in a Dutch bank without a full MBO diploma. Here her language capital (bilingual in Turkish and Dutch) and cultural capital as a person of Turkish origin worked in her favour.

The Turkish bank did not see Defne's lack of qualifications as an obstacle, as they were willing to provide on-the-job training. With help from a colleague, Defne received training and learned to handle basic transactions and administrative duties. After her "dirty and heavy jobs", Defne really enjoyed working at the bank. However, the economic crisis led the bank to reduce her full-time contract to a parttime one. Defne was afraid of losing her job and that that she wouldn't be able to get a similar job in a Dutch bank because of her lack of qualifications. This led her to decide to go back to school and start vocational training.

DEFNE: I have made up my mind. I have also told my husband that I cannot go back to cleaning or other jobs like that and he supports me. I want to do an MBO in banking and insurance.

Şakir and Defne's experiences reflect the conditions of young people entering the Dutch labour market, which is credentialist and places a high premium on possession of diplomas. Lacking such educational capital and resources at home, they developed skills through their jobs and social contacts. Şakir relied on his close circle of friends, while Defne's move to a more mixed neighbourhood and contact with a Dutch neighbour facilitated her transition from unskilled to skilled labour (Granovetter 2005). Both of their experiences form an interesting comparison with young people in possession of a vocational diploma in the Netherlands (see next section) and also their counterparts in Strasbourg.

\section{Early School Leavers in Strasbourg}

Despite high number of male early school leavers in Strasbourg, according to TIES Survey analysis (see Table 4.1), all the male respondents I could reach in the field had a minimum vocational diploma (CAP/BEP). Interestingly despite holding minimum qualifications, their labour market experience resembled the Dutch male early school leavers very much as they fell into low-skilled jobs. Their experiences will nevertheless be discussed in the following section. Below I present the stories of two female respondents, whom I could reach in the qualitative field and whose diverse educational ventures failed, leading them to drop out of school and pursue a transition pathway as homemakers. Fatmagul's decision to drop out was related to a structural obstacle: the headscarf ban that was introduced in France in 2004 (Hargreaves 2007). There has been an increase in Islamaphobic rhetoric in politics, 
and especially in the media in both the Netherlands and France, but France institutionalized this hostile discourse in 2004, creating a structural barrier to the education of young women who choose to wear headscarves in French state schools. This headscarf ban, like the one in Turkey, has led to discriminatory practices against women, as only headscarf-wearing Muslim girls are excluded, while Muslim boys not wearing any obvious religious symbols can continue their education without interruption. Fatmagül refused to take off her headscarf and decided to continue her studies from home. Losing contact with her peers made her feel isolated and she became less attentive to her coursework until eventually she quit school. She met a Turkish boy from her parents' village during the summer holidays. After 1 year of long-distance dating online, they got married. Her husband started working with Fatmagül's father on construction sites. Lacking any work experience, Fatmagül ended up stuck at home doing domestic chores while looking for low-skilled work. After her negative experience of being forced to leave school by the headscarf ban, she was not very optimistic about finding a job. At the time of the survey, she was hoping to start work as cleaner in a doctor's office, whom she had heard was not negative about young women wearing headscarves. For Fatmagül, marriage constituted a transition from home to greater independence. Like other young women who had dropped out of education without qualifications, she was actively looking for work, but the options available to her were few and mostly undesirable.

Another interesting case in Strasbourg was that of Ayla, discussed in Chap. 2 when exploring the difficulties of adjusting to the school habitus (Lehmann 2007). Unlike Fatmagül, Ayla was an outstanding pupil. Her teachers at secondary school (collège) recommended that she follow the academic track at the most prestigious lyceum in the centre of Strasbourg. However, after spending most of her education in segregated neighbourhood (quartier) schools, where most of her friends were also from an ethnic-minority background, Ayla could not adjust to the habitus of the new school where most of the students were upper-middle class, ambitious and very competitive. Unable to relate to or form connections with her classmates and teachers, Ayla's grades began to fall and she failed her oral baccalauréat exam. She then went on a summer vacation in Turkey, where she fell in love with a Turkish boy. He was studying in a Turkish University and they kept in touch online. When she returned to France, she decided to enrol once more to prepare for the baccalauréat exam. She was placed in a class with new students and, as the eldest pupil, she felt even more out of place. Shortly afterwards, she decided to drop out altogether, get married and move to Turkey. Her parents were disappointed but eventually agreed to her decision. She got married at the age of 18 in Turkey, where she stayed for around 1 year. Ayla acknowledges that she would have tried harder at school if she hadn't met her husband, but also stresses that she was disappointed and eager to leave.

AYLA: Let me say it this way; around the time I felt most detached from school, I met him. It just coincided. It was a when time I was getting discouraged from studying and my grades were falling. When we met I became even more confused. We started chatting and I just didn't care anymore. Maybe if I hadn't met him, I would have pulled myself together, but, yeah, this was the way it was supposed to be. I was only seventeen. 
Eventually the couple returned to France. Ayla and her husband had two children in the space of 3 years, and she stayed home to take care of them. Ayla's husband found a job with the help of her family, and also learnt some French. Ayla is planning on going back to school and she has modified her dream of being a doctor to getting a chemistry degree and becoming a teacher. She says her husband strongly supports her decision, and she has already signed up to take her baccalauréat exam.

These social trajectories of descendants of Turkish migrants who dropped out of education without a minimum diploma are revealing. First of all, none of the respondents displayed reactionary attitudes toward education. On the contrary, they all acknowledged the value of a diploma and tried to attend and do well at school. They experienced obstacles on the micro, meso and macro level. On the individual level, they lacked clear career pathways (Şakir). On the meso level they had problems at home (Defne), they had conflicts with teachers or peers (Şakir) or difficulty adjusting to the school habitus as in the case of Ayla, while on the macro level, structural barriers such as the headscarf ban (Fatmagul) led to them leaving education without a diploma. Leaving education without a diploma meant that most of them had to resort to low-skilled jobs, through which they tried to develop forms of capital to help them pursue their careers. These profiles also highlight a lack of clarity about when exactly transitions begin and end. While returning to school was not an option for Şakir, Defne or Fatmagül, Ayla still held hopes that this may improve her chances in the labour market. The gendered values held within the Turkish ethnic community has been another important aspect of their transitions. For many young women, marriage emerged as a transition pathway providing a way out of their 'stuck' transitions. Sometimes it offered a way to leave the parental home, while at others it was an alternative to school or the labour market.

\section{Post-secondary Vocational Graduates}

Figure 4.2 shows the post-school activities among those who left education with a post-secondary vocational diploma. Once more, caution should be taken with interpreting the data for the comparison group (especially in Strasbourg) as the sample was very small. We see different activity rates in both settings, where second- generation Turkish males in Strasbourg had higher activity rates and lower unemployment rates compared to those in Amsterdam. Once again looking after children is a common activity among the female respondents (also in the comparison group), although more so in Amsterdam than in Strasbourg.

The insights from the in-depth interviews do not provide much explanation for these trends. What is clear from the qualitative interviews is that most graduates of vocational training in Amsterdam found jobs that were related to their study and that matched their skills. In Strasbourg, most of the same group did low-skilled jobs, despite having post-secondary vocational qualifications. The higher unemployment rates in Amsterdam could be due to the fact that it may be ("more") difficult for second-generation males and females in Amsterdam to find employment in the area of their studies, compared to the second generation in Strasbourg, whom often had 


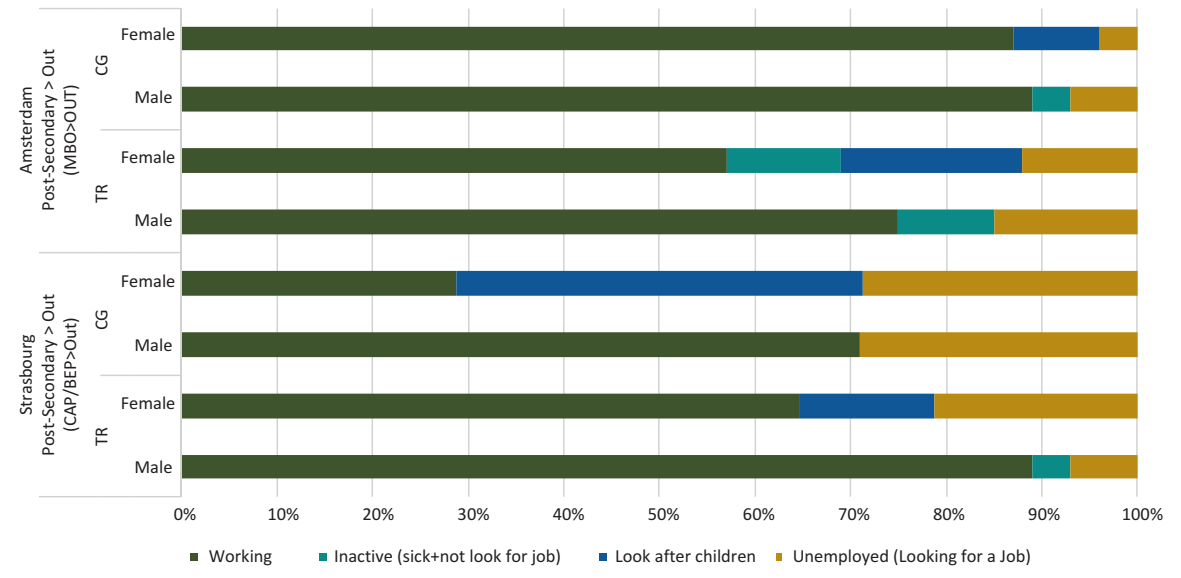

Fig. 4.2 Activity after school among vocational diploma holders. (Source: TIES Survey 2008)

to resort to unskilled jobs. The Dutch vocational training system provides schoolbased training supplemented by extended periods of internship that enable young people to gain occupation-specific skills. This internship experience marks the main difference between the settings with regard to youth transitions. Students in Amsterdam develop an understanding of the tasks they will perform in the workplace and the skills required by their jobs during their internships. Failure to find a good internship, where they can learn relevant skills, may form an obstacle to finding a job later on. My interviewees in Amsterdam often voiced concerns about finding appropriate internships as this could impact on their future employment prospects, a concern which was absent in Strasbourg.

Post-secondary Vocational Education Graduates in Amsterdam

Most vocational track respondents whom I interviewed in Amsterdam had trained for jobs in the service sector, such as banking and insurance, administration, IT or business. Hardly any of their parents were able to provide assistance or social capital in these sectors. As a result, most of them had to rely on the forms of capital, especially job-related information and social capital that they accrued through their internships and student jobs. Their internship experiences also provided them with information that sometimes led them to modify their occupational pathways. For example, Kuzey chose to study accounting and management at a post-secondary vocational training college (MBO), but after his internship, decided that he didn't want to spend the rest of his life making calculations on a computer. As a result, he switched to training as a security guard, as this allowed him to work outdoors with more flexible working conditions. He entered the labour market straight after completing his course. 
Gülden (aged 25 at the time of the interview) is the seventh child of an immigrant family from Turkey living in Amsterdam. Her profile shows how a lack of resources at home can be compensated for by vocational training (educational capital) and internship experience (cultural and social capital significant for attaining a job). The youngest in the family, she was the only sibling born in the Netherlands. Her father had retired from his manufacturing job and her mother had never been employed. Neither spoke good Dutch. Gülden was advised to choose the vocational track, and pursued senior secondary vocational training in banking and insurance, taking two 6-month internships. Through her studies and internship, she developed both social and cultural capital that were relevant to her future occupation. She built job-related skills, while also learning about time management, relations with colleagues and managing an agenda, skills that she had not come into contact with prior to her internship. In terms of social capital, her second employer, a corporate bank, offered her a job as a bank clerk while she was still studying. Two weeks after graduation, she started working there full-time. Although Gülden worked at the bank for 4 years she was never offered a permanent contract. When the economic crisis hit, she was made redundant, together with hundreds of other (low-ranking) employees. Before she left, her bank recommended her to a corporate Turkish Bank based in Amsterdam. She has now been employed there for over 2 years. She was even happier with her second job, as she gained new skills and had a higher position as her knowledge of the Turkish language and culture were crucial resources. Moreover her knowledge of the Dutch system and language were also significant forms of capital since most employees in the bank were recent Turkish migrants, who did not speak Dutch and were not familiar with the Netherlands. At the time of the interview, she still did not have a permanent contract, but was optimistic about getting one. Gülden was the highest-qualified person in her family, as her older brothers and sisters had little education. She never considered prolonging her studies into higher education.

INTERVIEWER: What do you think about labour market opportunities in the Netherlands?

GÜLDEN: Let me tell you this. I studied MBO, but I can find a job much more easily than an $\mathrm{HBO}$ graduate. Really! Because [HBO graduates] are more expensive. Employers have to pay them more to do the same job. That's why MBO graduates can find a job more quickly.

During this period, Gülden married another first-generation migrant from her parents' hometown in Turkey. He had left university without a diploma and is dissatisfied with the opportunities available to him in Amsterdam. The couple were still living with Gülden's family, waiting for social housing and her husband was working through contacts provided by her family. For Gülden, marriage simply accompanied her pathway rather than creating an alternative or a way out but her marriage decision was also comparable to rest of the women in my sample.

Most of male and female respondents in the vocational track married young and chose partners from the Turkish community, who were either from the first or second generation. Marriage emerged as a transition pathway while they were mostly following institutionally informed transitions from education to work.

The interviews with vocational students in Amsterdam underlined the importance of the internship experience in which they acknowledged the importance of vocational skills in facilitating their transitions. The majority of respondents from 
the vocational track in Amsterdam found jobs that were related to their studies and many through their internships or contacts they made during their internships. By contrast, there were no instances of this among my respondents from post-secondary vocational education in Strasbourg.

\section{Post-secondary Vocational Education Graduates in Strasbourg}

Vocational educational in France is less occupational-skill-specific than in the Netherlands (Powell et al. 2009). Yet, the skills required for jobs are usually gained in the work place and, therefore there is not a clear link between educational credentials and occupation (Hannan et al. 1997). In France, most respondents with vocational diplomas found that their qualifications did not pave the way to suitable employment and, instead, they ended up in a range of low-skilled jobs. This is perhaps partly due to the increase in educational credentialism in France, which places great emphasis on encouraging young people to get a BAC, which means that vocational qualifications have become devalued (Duru-Bellat and Kieffer 2008). Many of the respondents said that the CAP/BEP vocational diplomas had become increasingly redundant over the past 10 years. This change was also voiced by older and younger respondents; older respondents saying when they graduated BEP/CAP diplomas counted more compared to younger respondents claiming the opposite.

Most male vocational students in Strasbourg had learned manual trades, such as auto mechanics, maintenance work, plumbing and technical repairs, while the females studied accountancy or administration, and one even studied sewing. When they entered the labour market, most male respondents started working on assembly lines, construction sites or as vendors in the market place. These were the kind of jobs that they could easily access via family members or by registering at employment agencies (interim). In contrast, those who left school with a baccalauréat worked in stores as sales assistants, bus drivers or did other jobs, mostly in the service sector. Many male respondents did not consider further training as a viable option as they wanted to start working and earning an income as soon as possible. These students had started working in family businesses, such as market stalls, bazaars or construction sites.

The case of Selahattin exemplifies the financial pressures felt by most male descendants of migrants that prompted them to leave education as soon as they learned a trade in a vocational programme (even though they did not use this trade in the labour market). He is the youngest child of a migrant family from Turkey, the only member of the family born in France, his other siblings had low-skilled jobs. Obtaining his BEP diploma in plumbing made him the highest qualified person in his family. Even though Selahattin's grades were above average, he never considered higher education as he wanted to earn an income, get his driving license, buy a car and become financially independent. He therefore left education after gaining his vocational diploma (BEP). Yet despite having a vocational diploma ("trade") Selahattin did not find work as a plumber, but became a street vendor in a market stall, together with his brother. After 4 years in the market, he concluded that street stalls were no longer sufficiently profitable, so they closed their stall and Selahattin 
started working on assembly lines. He found jobs through employment agencies (interim), and changed employment constantly, never receiving a permanent contract. Some time before our interview he was injured at work and had to have an operation on his spine, which was followed by a year of sick leave. He was planning on returning to work in the factory. His ambition was to acquire a stable labour market position, get married and start a family. Selahattin was 29 at the time of the interview, and had been working since he left school at age 17. Having a vocational diploma had clearly done little to help Selahattin find a job related to his course or secure a stable position on the labour market. Instead he moved from one physically demanding job to the other. His case was very similar to my other Turkish respondents from Strasbourg with the same level of qualifications who had found employment but never achieved stable careers that were related to their vocational diplomas.

\section{Post-secondary Academic Education Graduates}

One striking difference between Amsterdam and Strasbourg is that some of my interviewees in Strasbourg left school after receiving an academic tertiary (baccalauréat). Whereas in Amsterdam such pathways are extremely rare. This was also evident in the TIES survey which showed that dropout rates were much lower among academic and general track pupils in Amsterdam than in Strasbourg. According to Table 4.1,21\% of the respondents with Turkish immigrant parents and $22 \%$ of the respondents with French parents left education with a bac diploma. In contrast Table 4.2 shows that $5 \%$ of the descendants of Turkish migrants and $8 \%$ of the comparison group left education after academic upper secondary education (HAVO/VWO).

Hence in this section I will provide a case study from Strasbourg with the aim to exemplify the profiles dropping out of baccalauréat. Although an academic diploma was clearly more prestigious than a vocational qualification such as BEP/CAP, my interviewees in France disputed the advantages provided by a baccalauréat, saying that a baccalauréat "means nothing by itself", as it only provided evidence of a high level of general education but had no professional orientation. However having a baccalauréat did not motivate them to pursue higher education: partly because they were not convinced that a higher education diploma would really guarantee competitive advantage in the labour market and partly because many of them felt under pressure to earn a living and felt unwilling or unable to postpone their labour market entry for 4 years.

Engin, from Strasbourg, left education with a bac tech. His mother had come to Strasbourg at the age of 12, and received some language training. She spoke good French and worked in the European Parliament as a cleaner. His father joined her after their marriage and worked as a butcher. The family lived in the suburbs of Strasbourg, where the schools had a bad reputation so Engin's parents sent him to a private school outside the neighbourhood. Yet after getting his technical baccalauréat diploma, Engin did not want to go to university, arguing that it would not give 
him any occupational skills or experience relevant to the labour market. Instead, he tried to enrol in a tertiary vocational school which offers long periods of internship experience (BTS en alternance).

ENGIN: I have never wanted to go to university because you can't gain any experience there. Then there is BTS. There is one public one. I didn't want that either because there you only go to school. Again, you don't work, you don't make money or gain any experience. I needed to make money, you know and I also wanted to work and gain some experience. That's why I tried BTS en alternance. I sent my CV to nearly 100 employers; people we know, acquaintances, family, friends. I also looked on the Internet; [I found] nothing. Then I looked for a job and started working at Zara.

Unlike university or other forms of vocational tertiary training, BTS en alternance combines 2 days of in-school training with 3 days of working for an employer. In many ways it is similar to the dual study programmes in Amsterdam (which are available both in post-secondary vocational training and in the tertiary vocational track). Most students who access this training develop relevant job experience that is related to their studies and end up getting offered a job with the same employer, thereby experiencing a smooth labour market entry. However, this new form of BTS is highly selective. Students need to find an employer who will finance their studies in return for a lower wage, equivalent to the official minimum income (Smig). Engin tried hard to access one but did not succeed. At the time of the interview, his plan was to save money and start his own business.

In Strasbourg, uncertainty about the usefulness of tertiary education diplomas and pressure to earn an income (especially among males) contributed to young people's decisions to drop out of education after academic post-secondary education. There were no instances of this among my respondents in Amsterdam, where respondents were reassured about the returns of higher education as we will see below.

\section{Higher Education Graduates}

When we look at activity levels of those who left education with a higher education diploma; we see higher unemployment rates among descendants of migrants from Turkey than among the comparison group, especially in Amsterdam. General statistics show that, since 2003, second generation migrants in the Netherlands with higher vocational training suffered higher unemployment rates than their Dutch peers (Hoger Onderwijs Bureau 2015) (Fig. 4.3).

In the coming sections, I will concentrate on the qualitative interviews with respondents who been through higher education. These interviews help explain the mechanisms behind the transition processes of highly-educated descendants of migrants. The respondents' profiles are utilized to show that prolonging one's educational trajectory into higher education is not a straightforward activity, but one that requires both resources and support from one's family and significant others. 


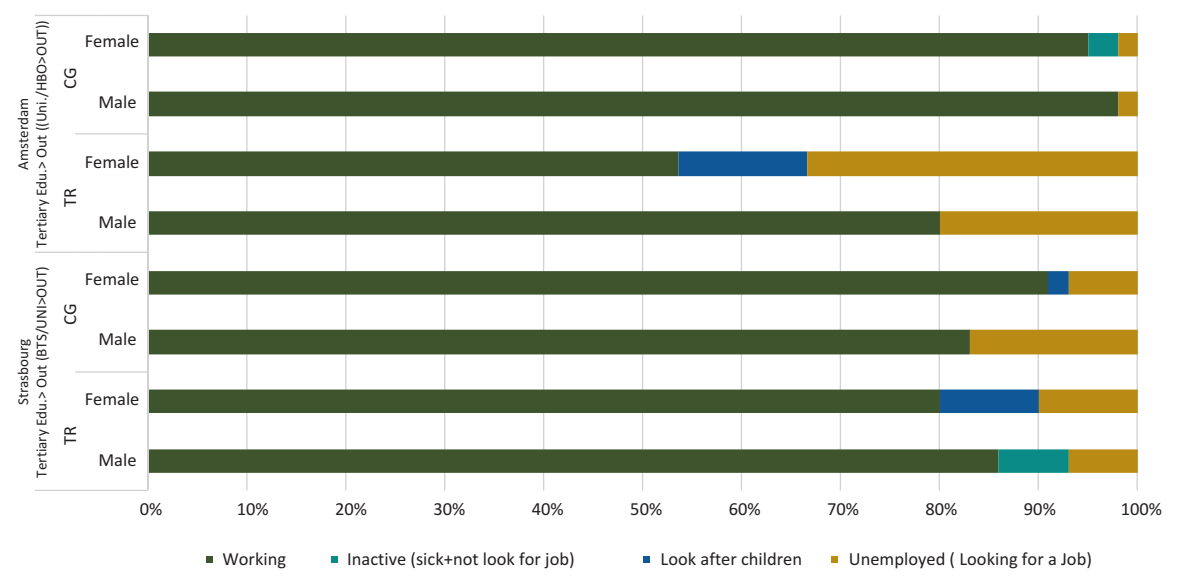

Fig. 4.3 Activity after school among higher education diploma holders. (Source: TIES Survey 2008)

Some institutional structures facilitate the prolongation process; the efforts required to extend one's schooling into tertiary education is not the same for academic and vocational track students and there were differences between Amsterdam and Strasbourg. Furthermore, providing detailed transition experiences of well-educated descendants of migrants, helps to shed a light on the reasons for the high unemployment rates observed within the group.

Academic Track Students' Experiences of Higher Education and Beyond: Prolongation Practice

When accessing higher education, academic track pupils in Amsterdam experienced a rather smooth decision-making process. Through early stratification, most respondents had been prepared and conditioned to enter their assigned higher education track without further consideration (HAVO students go to HBO and VWO students go to University) and they were confident about the returns of higher education. However, as discussed in the previous section, the lack of transparency regarding the benefits of higher education in France meant that accessing higher education was not so straightforward for some academic track students in Strasbourg. Nevertheless, a considerable number of baccalauréat holders did go onto universities or higher vocational institutions.

In order to prolong their transition young people depend on support provided by their families. As discussed in Chap. 1, parents who had arrived earlier in the host countries and had been able to develop language skills and cultural capital concerning the education system were better placed to be supportive of their children's schooling. 
Bulut from Amsterdam and Zeynep from Strasbourg relied on the support provided by their families to extend their educational careers. After graduating from vocational college (HBO) with a degree in business administration, Bulut did a 2-year MA degree in finance. She received full support from her parents, who not only covered the cost of her studies but also provided an ideal working environment, in which she had her own room and meals were organized according to her study schedule. Both of Bulut's parents had arrived in the Netherlands at the age of 12 and attended Dutch schools. Aware of increasing credentialism, they used all the means at their disposal to support Bulut. After acquiring her HBO degree, Bulut enrolled in a university. First she had to do a pre-Masters year and take additional courses in philosophy, maths and English. English was the most difficult subject for her, and she had to pay for private classes. In the end, she successfully completed the programme and acquired her MA degree.

One feature that emerges from Bulut's biography is that attending higher education allowed her to enlarge her circle of friends and social contacts. Her internship experiences, in particular, gave her the opportunity to develop social capital that was crucial for her (future) youth transitions. Throughout the interview she emphasized that she had also benefited greatly from her internship experience during her HBO and her interactions with her classmates. During her vocational degree course, Bulut did an internship with a prestigious Dutch private bank, a position she gained through a 'well-off' classmate whose father was a well-respected dentist. She later obtained a part-time position at ABN-AMRO during her MA studies, and thinks that her previous internship experience was instrumental in this:

INTERVIEWER: What do you think about your work experience as a student?

BULUT: I think where you work as a student or where you do your internship matters a lot.

I think I got this job at ABN because I had worked at the private bank. Because once, the head of the department came to visit the workers there, and he almost never talks to the students. He approached me and said "Hey you were the girl who did an internship at that private bank?" I remember it well, because it is very difficult to get into that place.

After graduation, Bulut wanted to take a break for a couple of months before looking for a job, as she was tired of studying hard and wanted to organize her engagement party. Her fiancée was a descendant of Turkish migrants who was born and raised in Amsterdam and worked as a police officer. Just after the summer, Bulut was approached by a head hunter, who arranged a temporary post for her in the finance department of a corporate firm located close to Amsterdam. She took this opportunity to build work experience, commuting $2 \mathrm{~h}$ every day. Six months later, both Bulut and the company were pleased with her performance, and she was offered a position in one of their branches in Amsterdam. After 2 years, she was offered a permanent contract, which she happily accepted. In the meantime she had also got married and at the time of the second interview she and her husband were considering buying an apartment.

In Strasbourg, Zeynep studied IT management at tertiary vocational school (BTS). Her subject choice had been totally by chance: she decided to try IT because this was the only training which still had space for a new student. She enjoyed the 
course and pursued it further. In contrast to Bulut, Zeynep only had very short internship periods, but they still proved useful for her future transition. Zeynep's father had come to France at a young age, attending school there and developing language skills and cultural capital. He advised Zeynep to go to university rather than entering the labour market. He provided full emotional and financial support for her to access a license professional and Zeynep successfully completed her bachelor's degree course. After graduation, she spent 6 months looking for a job before eventually finding a post in the public sector at one of her former internships. At the time of the interview, she had been working there for over a year. Recently she had been given a permanent position (embouché).

Both Zeynep and Bulut had parents who arrived in the Netherlands and France around the age of 12 and received education in the host countries. Both sets of parents had language capital and information capital about the education system and how the labour market functions. Furthermore, while pursuing the tertiary vocational track, both Zeynep and Bulut were able to conduct internships and develop their own cultural and social capital that facilitated smooth labour market transitions. Bulut's work experience was much more substantial than Zeynep's, and hence her income and contract were also quite prestigious. However, even Zeynep's meagre internship experience proved to be very useful in establishing contacts.

It is also very important to note that all the female respondents in this category expressed a wish to get married, but postponed doing so until they had finished their studies and found employment, in contrast to other respondents who dropped out of education without a degree or gave up on their labour market prospects.

Vocational Track Students' Experiences of Higher Education and Beyond: Prolongation Practice

While for academic students, like Zeynep and Bulut, the decision to pursue higher education was more or less a given, this decision was less straightforward for vocational students, who had to follow a longer trajectory to access higher education. In Amsterdam, prolonging one's education into tertiary education also carries the risk of having to repay the conditional student loan in the event of failure to graduate. This discourages many young people from low income families. Once in possession of a vocational degree, these young people were not only worried about the expense or time involved in studying, but also about missing out on earnings by not entering the labour market (Giroux 1983). In order to prolong their education for another 4 years, they needed various support mechanisms and opportunity structures.

As discussed in the previous section, parental support was even more pivotal for vocational track students. Although their parents were unable to provide practical assistance or give advice on educational choices, they could create the right environment for further study by giving their children emotional or financial support and alleviating their economic concerns about delaying full-time employment that 
would otherwise have formed a solid barrier for them. Serkan's parents exemplified such support, enabling him to extend his studies into tertiary vocational education. Serkan's mother had arrived in the Netherlands at the age of 12, attended vocational school, and become fluent in Dutch. Serkan's father was from his maternal grandparents' village, and together the couple started their own successful dry-cleaning business. Serkan's parents had always been very supportive of their children. Serkan's older brother didn't want to extend his studies: after his vocational degree, he started working in the family business, opening his own branch. Serkan obtained an $\mathrm{MBO}$ degree in sports and physical education. His dream was to become a professional football player. He said that his mother would come to all his games and he always felt he had his parents' backing in all his decisions. However, after a few unfortunate high-risk injuries followed by serious operations, Serkan concluded that there was no future for him in professional football. Then he made a substantial change and decided to attend tertiary vocational education (HBO) in business economics.

SERKAN: I went through two serious operations on my knee. Then I decided that I didn't have a future in football. School is more important for me. You develop yourself and meet different people. When you tell people you are studying at an HBO, they look at you differently. You know, with more respect. I decided to do HBO in business economics. It's more prestigious, you know; when you get a job they give you a car and so on. It's cool.

Serkan not only attributed employment value to tertiary education (Lehmann 2009), but also praised the status and prestige that a higher education diploma brought with it. He already planned on pursuing his studies into university, which is even more reputable. His efforts were welcomed by his parents. Serkan emphasized that he had a part-time job as a gym instructor and paid for his own study costs. However, he also mentioned that his father was ready to pay for anything as long as he was willing to study. Even though his parents could not help Serkan with his course or studies, they still created a supportive environment for him.

Not all the students in Amsterdam who accessed higher education training managed to complete their studies or felt supported to the same extent. Financial support from one's family was a crucial dynamic in Amsterdam, as the obligation to repay the student loan if one dropped out of tertiary vocational education was a major deterrent. The risk of failure was exacerbated by the fear of incurring a debt after one had delayed full-time employment. These obstacles mean that vocational track students need to have dedication, a clear goal and be resilient. In Amsterdam, Emre was among the students who experienced cyclical periods of employment, training and unemployment. He had already embarked on three different HBO courses, but hadn't completed any of them. He had an MBO diploma in trading and sales, but didn't enjoy working in that field. He said that, during his internships, he had not worked in the area of his studies, but had counted his work in a supermarket as internships. Consequently, he had no idea of what awaited him on the labour market. As a result, he ended up working mostly in low-skilled jobs at the airport or in supermarkets, or trying new training courses. 
In Strasbourg, financial obligations and lack of parental support made it particularly difficult for students to access higher education as combining work and study was not a feasible option. Behzat's case was discussed in the previous chapter. After attaining his vocational degree, he first went to the professional lyceum and then accessed vocational tertiary education. Being forced to work while studying led him to drop out. Behzat's father had arrived in Strasbourg as a guest worker. He had little education and worked in factories until his retirement. Behzat was the family's youngest child, and his parents were already retired by the time he went to school. His father was not very supportive of his decision to undertake further study. On the contrary, Behzat felt that he was expected to start working full time as soon as possible, but as he wanted to study further, he decided to take a part-time job. This became too demanding and eventually he dropped out of school and started doing factory work full-time. During the interview, Behzat was quite regretful and angry about dropping out because after quitting BTS, he had managed to find a job through his internship, even though he did not have a BTS diploma. Despite having a permanent contract, Behzat was afraid that if the factory closed down he would not be able to find another job at BTS level.

Another important factor that affected whether or not respondents accessed higher education was taking a risk-averse strategy, as is illustrated by Şebnem's story. Previous studies have examined risk averse behaviour regarding higher education, especially among female descendants of immigrants from Turkey (Pasztor 2009). However, this type of risk aversion was different from the ones applied in most studies (Van De Werfhorst and Hofstede 2007); my respondents were not avoiding downward mobility as they had already achieved upward social mobility compared to their parents. However, they took a guaranteed or instrumental approach. Most respondents chose easier pathways to avoid the risk of failure, and considered it easier to 'fall back on' a vocational degree in the event of failure. Şebnem had immigrant parents with a low education level. After school, she decided to attend a vocational college, despite her above average grades, as she preferred to start work rather than go to university and thought that a vocational degree would be sufficient. Her experience in vocational training was rewarding, and, together with her best friend, who was from a similar background, she was advised by her teachers to attend professional lyceum. Working with her peer proved to be a successful strategy for Şebnem, as it is for many other children of immigrants (Crul 1999, 2000). Once they graduated from professional lyceum, they both decided to attend university. Şebnem was determined to stay low profile so chose a subject (sociology), which was accessible but also easy to succeed at.

At university, Şebnem met her husband. A law student, he was also the child of Turkish immigrants. They decided to get married in their second year and Şebnem moved in with her husband's mother. She started working part time in childcare centres alongside her studies in order to contribute to the family income. One year later, she had her first child. She mentioned that living with her husband's mother had been very helpful, as her mother-in-law would take care of the child and do 
most of the household tasks. Şebnem managed to get her bachelor degree with a 2 -year delay, together with additional training in child care (formation). Hence she managed to study, work and start a family, all at the same time. She accumulated significant experience in the education sector, and found a job in a mixed school as a manager dealing with parents and children with a migrant background. Şebnem mentions that she never had high ambitions about higher education, but had just made sure that she obtained all the diplomas as she climbed the ladder. Şebnem's case is not only an example of an extended educational career, but also shows the complexities of today's transitions. She managed to combine her studies with work, marriage and child rearing.

However, in doing so, she relied heavily on family support. These resources are reminiscent of the forms of gendered capital discovered by Skeggs (2004a) among working-class mothers. Many mothers' altruistic behaviour has facilitated a successful transition for the female descendants of immigrants. This is a distinct form of family support, whereby parents provide assistance in dealing with the difficulties of married life, domestic responsibilities and combining work with studies. Thus marriage continues to be a valid cohabitation practice for native-born descendants of immigrants from Turkey, and is not necessarily an alternative to working or education if the extended family is willing and able to facilitate distinct combinations of all these activities.

\subsection{Conclusion: Gendered Pathways and the Role of Family Support}

Previous studies have argued that, in today's societies, youth transitions are becoming more extended, fragmented and complex. In this chapter, I illustrate the struggles of the native-born descendants of immigrants from Turkey in Amsterdam and Strasbourg during their transition from school to various forms of adulthood. In doing so I have tried to show that the prolonged nature of transitions, whose newness is also debated (see Coté and Bynner 2008) cannot be taken for granted and that young people face financial pressures and structures that either impede or enhance the opportunities available to them during their transition pathways.

The study's comparative design uncovers structural similarities and differences between Amsterdam and Strasbourg. First of all, young people's capacity to continue their studies into higher education was strongly influenced by their initial tracking: academic track students were more likely to extend their studies into tertiary education in both cities. However the perceived value of (higher education) qualifications were pivotal in working class youths' educational decisions (Lehmann 2007). Confirming Lehmann's argument, my interviewees' decisions to enter higher education were informed by their perceptions of whether the benefits of higher educational degrees would outweigh the cost of delaying entry to the labour market, 
by up to 4 years. In Amsterdam the decision to continue on to tertiary education was more straightforward than in Strasbourg, where doubts about the value of additional qualifications often caused students avoid such a course of action. This led many of my interviewees in France to drop out of education after receiving their lyceum diploma. This finding is backed up by quantitative data from the TIES survey (date) which shows that $21 \%$ of descendants of migrants in Strasbourg left education with a lyceum diploma, compared to 5\% in Amsterdam (See Tables 4.1 and 4.2). This emphasizes the educational decisions of people with very similar resources and backgrounds are strongly conditioned by structural features, which have a profound effect on these people's transition pathways and outcomes.

In both settings parental support was critical in assisting transition decisions. All of the respondents of this study in both settings originated from lower-class families. None of the parents were able to provide instrumental support such as advising on educational decisions or career choice or helping with course work (Rezai et al. 2015). Nevertheless parental support mechanisms (Jones 2009) were crucial, even when they do not take the form of middle-class knowledge of how the educational and employment systems work (or possessing social capital within them). Economic capital was especially crucial in creating a comfort zone that allowed young people to extend their studies without worrying about earning an income. Emotional capital and practical help from parents in sharing daily responsibilities also helped respondents achieve a complex transition. Skeggs (2004b) has highlighted the importance of the forms of capital possessed by working-class mothers, which do not, in Bourdieu's terms have an exchange value. Reay (2004) also refers to this as emotional capital and show that it and can still provide great advantage. The arguments of Skeggs (2004b) and Reay (2004) were confirmed by my data; immigrant parents are able to provide emotional capital, which can prove very effective. In fact lack of such support made it virtually impossible for descendants of migrants to prolong their transitions successfully.

The lack of instrumental support or absence of social capital provided by parents increased the importance of another institutional structure: internship and educationrelated work experiences. Unable to access crucial work contacts through their parents, descendants of migrants relied heavily on the contacts and skills built during their internships. A successful internship experience led to both the development of competences and cultural capital about employment practices, and also generated social capital, which was vital in accessing jobs. This was more the case in Amsterdam than in Strasbourg since vocational and tertiary vocational education in the Netherlands require extended internship periods. However this also implied that a lack of such internship experience had more negative consequences for young people in Amsterdam. In Amsterdam, vocational track students who were not able to benefit from an instrumental internship experience-or, even worse, who dropped out of the vocational track without a diploma-had limited options such as lowskilled service jobs or labour-intensive employment, as we have seen with the profiles of early school leavers. While some of these young people repeatedly became unemployed, others built cultural capital through their work experience, establishing weak ties to find their way back into career tracks. In France, the lack of internship 
experience among vocational students did not result in much deviation: respondents with or without a vocational diploma ended up in low-skilled employment in manufacturing or the service sector. Young people working in these jobs worked under demanding conditions, relied heavily on employment agencies which contracted them to temporary arrangements, eventually making it difficult to achieve stability.

For academic track students in both settings, employment practices in the area of their studies proved to be instrumental in developing different forms of capital, especially social capital. In fact, highly-educated respondents almost exclusively relied on the social capital that they had developed themselves throughout their studies or internships or work experience. This could provide an explanation for the high unemployment rates among higher education graduates in Amsterdam (Hoger Onderwijs Bureau 2015). A lack of relevant internship experience where they can build resources leaves descendants of migrants without assistance in their transitions to work.

Finally, another interesting finding from this detailed study of transitions is marriage as an alternative transition pathway, especially voiced and applied among female respondents. The prevalence of marriage at an early age among descendants of migrants existed in parallel to other transition practices and added to the complexity of the picture. Marriage continues to be the most acceptable and common form of cohabitation and child-rearing for both the male and female native-born descendants of immigrants from Turkey in Europe (Milewski and Hamel 2010). However marriage as a transition pathway has been widely ignored in transition studies, due to changing practices among the general population (Willoughby et al. 2015). Yet, especially for female descendants of migrants who fail at school or despair of finding a job, marriage provided an alternative transition pathway. This adds to the complexity of their transitions as some manage to combine marriage and children with school and part-time work with the help of parents or extended family. As a result this chapter did document prolonged and complex youth transitions among Turkish descendants of immigrants yet the conditions and consequences of this complexity and prolongation varied across institutional settings and depended heavily on the resources of young people circumscribed by the individuals' social class, gender and ethnicity.

\section{References}

Andersen, R., \& Van de Werfhorst, H. G. (2010). Education and occupational status in 14 countries: The role of educational institutions and labour market coordination. The British Journal of Sociology, 61, 336-355.

Blossfeld, H. P. (2008). Young workers, globalization and the labor market: Comparing early working life in eleven countries. Cheltenham: Edward Elgar Publishing.

Bol, T., \& Van de Werfhorst, H. G. (2013). Educational systems and the trade-off between labor market allocation and equality of educational opportunity. Comparative Education Review, 57(2), 285-308. 
Brinbaum, Y., \& Guégnard, C. (2011). De l'orientation au sentiment de discrimination: Parcours de formation et d'insertion des jeunes issus de l'immigration. [Orientations towards feelings of discrimination: Education and transition pathways of young people with migration background]. Net.Doc 78, Cereq, Marseille.

Brinbaum, Y., \& Guégnard, C. (2013). Choices and enrollments in French secondary and higher education: Repercussions for second-generation immigrants. Comparative Education Review, 57(3), 481-502.

Brown, P. (1987). Schooling ordinary kids: Inequality, unemployment, and the new vocationalism. London: Tavistock Books.

CBS. (2012). Turkse Ingezetenen in Nederland 2011. Den Haag: Centraal Bureau Voor Statistics.

Côté, J., \& Bynner, J. M. (2008). Changes in the transition to adulthood in the UK and Canada: The role of structure and agency in emerging adulthood. Journal of Youth Studies, 11(3), 251-268.

Crul, M. (1999). Explanations for success among second-generation Moroccan and Turkish youth in the Netherlands: A theory of practice. Amsterdam: Het Spinhuis.

Crul, M. (2000). Breaking the circle of disadvantage: Social mobility of second-generation Moroccans and Turks in the Netherlands. In H. Vermeulen \& J. Perlmann (Eds.), Immigrants, schooling, and social mobility: Does culture make a difference? (pp. 225-244). Houndmills/ Basingstoke/Hampshire/New York: Macmillan Press.

De Vries, M. R., \& Wolbers, M. H. J. (2005). Non-standard employment relations and wages among school leavers in the Netherlands. Work, Employment \& Society, 19(3), 503-525.

Delsen, L., \& Poutsma, E. (2005). Labour market institutions and economic performance in the Netherlands. International Economic Journal, 19(2), 169-196.

Duru-Bellat, M. (2000). Social inequalities in the French education system: The joint effect of individual and contextual factors. Journal of Educational Policy, 15(1), 33-40.

Duru-Bellat, M., \& Kieffer, A. (2008). From the Baccalauréat to higher education in France: Shifting inequalities. Population, 63(1), 119-154.

Eckert, H. (2005). Les «Bac Pro» À L'usine, Ou Le Travail Du Désenchantement. Recherches, 289-299.

Eurostat. (2010). Key indicators for core cities. European Commission. Available at: Http:// Eppeurostat.Ec.Europa.Eu/Portal/Page/Portal/Region_Cities/City_Urban/Data_Cities/ Databasa_Sub1

Furlong, A. (2009). Handbook of youth and young adulthood. New perspectives and agendas. London: Routledge.

Furlong, A., \& Cartmel, F. (1997). Young people and social change individualization and risk in late modernity. Buckingham: Open University Press.

Gaskell, J. (1992). Gender matters from school to work. Toronto: Oise Press.

Giroux, H. A. (1983). Theories of reproduction and resistance in the new sociology of education: A critical analysis. Harvard Educational Review, 53(3), 257-293.

Granovetter, M. (2005). The impact of social structure on economic outcomes. The Journal of Economic Perspectives, 19(1), 33-50.

Hannan, D. F., Raffe, D., \& Smyth, E. (1997). Cross-national research on school to work transitions: An analytical framework. Background paper prepared for the planning meeting for the thematic review of the transition from initial education to working life.

Hargreaves, A. G. (2007). Multi-ethnic France immigration, politics, culture and society. New York/London: Routledge.

Hoger Onderwijs Bureau. (2015, July 13). Allochtone hbo'ers komen moeilijk aan de bak. Retrieved from https://punt.avans.nl/2015/07/allochtone-hboers-komen-moeilijk-aan-de-bak/

Iannelli, C., \& Raffe, D. (2007). Vocational upper-secondary education and the transition from school. European Sociological Review, 23(1), 49-63.

Jones, G. (2009). From paradigm to paradox: Parental support and transitions to independence. In I. Schoon \& R. K. Silbereisen (Eds.), Transitions from school to work: Globalization, individualization, and patterns of diversity (pp. 145-164). New York: Cambridge University Press. 
Kalmijn, M., \& Kraaykamp, G. (2003). Dropout and downward mobility in the educational career: An event-history anaylsis of ethnic schooling differences in the Netherlands. Educational Research and Evaluation, 9(3), 265-287.

Kloosterman, R., \& Rath, J. (2001). Immigrant entrepreneurs in advanced economies: Mixed embeddedness further explored. Journal of Ethnic and Migration Studies, 27(2), 189-201.

Lehmann, W. (2004). 'For some reason, I get a little scared': Structure, agency, and risk in schoolwork transitions. Journal of Youth Studies, 7(4), 379-396.

Lehmann, W. (2007). Choosing to labour? School-to-work transitions and social class. Ithaca: Mcgill-Queen's University Press.

Lehmann, W. (2009). University as vocational education: Working-class students' expectations for university. British Journal of Sociology of Education, 30(2), 137-149.

Longwell-Grice, R. (2003). Get a job: Working class students discuss the purpose of college. College Student Affairs Journal, 23(1), 40.

Macleod, J. (2009). Ain't no Makin' it. Boulder: Westview Press.

Maurice, M., Sellier, F., \& Silvestre, J. J. (1986). The social foundations of industrial power: A comparison of France and Germany. Cambridge: MIT Press.

Mellottee, L., Becquet, V., Danic, I., Lepape, M.-C., Leroy, P., Loncle, P., \& Muniglia, V. (2010). Country report: France governance of educational trajectories in Europe. Amsterdam: University of Amsterdam.

Meurs, D., Ariane Pailhé And Patrick Simon (2005). "Mobilité Intergénérationnelle Et Persistance Des Inegalites: L'acces À L'emploi Des Immigres Et De Leurs Descendants En France.” Paris: Ermes.

Milewski, N., \& Hamel, C. (2010). Union formation and partner choice in a transnational context: The case of descendants of Turkish immigrants in France. International Migration Review, 44(3), 615-658.

Mueller, W., \& Gangl, M. (Eds.). (2003). Transitions from education to work in Europe: The integration of youth into EU labour markets. Oxford: England University Press.

Nell, L., \& Rath, J. (2009). Am I Amsterdam? Immigrant integration and urban change. In L. Nell \& J. Rath (Eds.), Ethnic Amsterdam: Immigrants and urban change in the twentieth century (pp. 11-23). Amsterdam: Amsterdam University Press.

Pasztor, A. (2009). Different settings, different choosers? Applying Ball's framework on the case of second generation Turks. International Studies in Sociology of Education, 19, 203-215.

Pasztor, A. (2010). Imagined futures: Why business studies dominate the higher education choices of second-generation Turks in the Netherlands? Ethnic and Racial Studies, 35, 704-717.

Powell, J. J., Coutrot, L., Graf, L., Bernhard, N., Kieffer, A., \& Solga, H. (2009). Comparing the relationship between vocational and higher education in Germany and France (No. SP I 2009506). WZB Discussion Paper.

Raffe, D. (2003). Pathways linking education and work: A review of concepts, research, and policy debates. Journal of Youth Studies, 6(1), 3-19.

Rath, J. (2002). A quintessential immigrant niche? The non-case of immigrants in the Dutch construction industry. Entrepreneurship \& Regional Development, 14(4), 355-372.

Reay, D. (2004). Gendering Bourdieu's concepts of capitals? Emotional capital, women and social class. The Sociological Review, 52(s2), 57-74.

Remery, C., van Doorne-Huiskes, A., \& Schippers, J. (2002). Labour market flexibility in the Netherlands: Looking for winners and losers. Work, Employment and Society, 16(3), 477-495.

Rezai, S., Crul, M., Severiens, S., \& Keskiner, E. (2015). Passing the torch to a new generation: A qualitative study of the highly educated second generation's receiving of parental support and giving of support to the younger generation. Journal of Comparative Migration Studies, 3, 12.

Skeggs, B. (2004a). Class, self culture. London: Routledge.

Skeggs, B. (2004b). Exchange, value and affect: Bourdieu and 'the self'. The Sociological Review, 52(2_suppl), 75-95.

Tesser, P., \& Dronkers, J. (2007). Equal opportunities or social closure in the Netherlands. Proceedings of British Academy, 136, 359-401. 
Van De Werfhorst, H. G., \& Hofstede, S. (2007). Cultural capital or risk aversion? Two mechanisms for educational inequality compared. British Journal of Sociology, 58(3), 391-415.

Van der Velden, R. K., \& Wolbers, M. H. (2006). How much does education matter and why? The effects of education on socio-economic outcomes among school-leavers in the Netherlands. European Sociological Review, 23(1), 65-80.

Willis, P. E. (1977). Learning to labor: How working class kids get working class jobs. Farnborough: Saxon House.

Willoughby, B. J., Hall, S. S., \& Luczak, H. P. (2015). Marital paradigms: A conceptual framework for marital attitudes, values, and beliefs. Journal of Family Issues, 36(2), 188-211.

Wolbers, M. H. (2003). Combinaties van werken en leren onder jongeren in Europa. Tijdschrift voor Arbeidsvraagstukken, 19(1), 20-33.

Wolbers, M. H. J. (2008). Increasing labor market instability among young people? Labor market entry and early career development among school-leavers in the Netherlands since the mid1980s. In H. Blossfeld (Ed.), Young workers, globalization and the labor market: Comparing early working life in eleven countries (pp. 77-101). Cheltenham: Edward Elgar Publishing.

Wolbers, M. H., De Graaf, P. M., \& Ultee, W. C. (2001). Trends in the occupational returns to educational credentials in the Dutch labor market: Changes in structures and in the association? Acta Sociologica, 44(1), 5-19.

Wyn, J., \& Dwyer, P. (1999). New directions in research on youth in transition. Journal of Youth Studies, 2(1), 5-21.

Zdrojewski, S. (2011). Ethnic disadvantages at labor market entry in France? In H. P. Blossfeld \& D. Hofäcker (Eds.), Youth on globalised labour markets: Rising uncertainty and its effects on early employment and family lives in Europe (pp. 121-162). Opladen/Farmington Hills: Barbara Budrich Publishers.

Zdrojewski, S., Grelet, Y., \& Vallet, L.-A. (2008). Increasing employment instability in France? Young people's labor market entry and early career since the 1990s. In H. Blossfeld (Ed.), Young workers, globalization and the labor market: Comparing early working life in eleven countries (pp. 103-127). Cheltenham: Edward Elgar Publishing.

Open Access This chapter is licensed under the terms of the Creative Commons Attribution 4.0 International License (http://creativecommons.org/licenses/by/4.0/), which permits use, sharing, adaptation, distribution and reproduction in any medium or format, as long as you give appropriate credit to the original author(s) and the source, provide a link to the Creative Commons licence and indicate if changes were made.

The images or other third party material in this chapter are included in the chapter's Creative Commons licence, unless indicated otherwise in a credit line to the material. If material is not included in the chapter's Creative Commons licence and your intended use is not permitted by statutory regulation or exceeds the permitted use, you will need to obtain permission directly from the copyright holder.

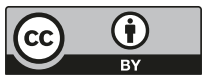




\section{Chapter 5}

\section{A Typology of Transition Trajectories}

\subsection{Introduction}

There is an ongoing debate among youth sociologists on whether transition processes still take the form of traditional sequences or diverge from conventional patterns. Traditional transitions are generally described as smooth processes that follow institutionally predictable, linear pathways from school to work (Evans and Heinz 1994). Young people may, however, diverge from linear trajectories by experiencing periods of unemployment, shifting between different employment statuses or by changing direction, contrary to expectations created by their previous trajectory. The discussion centres on whether shifting transitions are caused by a desire to try alternative pathways or if structural conditions are forcing young people into precarious situations.

So far I have pursued a retrospective approach to understanding youth transitions, showing that transitions are to some extent pre-conditioned by educational stratification, whereby young people develop distinct compositions and volumes of capital in distinct institutional settings and are exposed to different structures. Their transitions may be further shaped by early exposure to the labour market through various combinations of work and study. The previous chapter introduced the idea of social trajectories, during which young people develop different forms and volumes of capital required for their transitions. The comparative analysis showed differences between the settings: in Amsterdam, young people who were able to develop different forms of capital during their vocational or academic tracks could utilize these resources during their transitions, while, in Strasbourg, youngsters unable to develop such resources had to resort to low-skilled jobs, even if they had a diploma.

I will now go one step further by studying how the trajectories of native-born descendants of immigrants from Turkey developed after they left education. The most common way to study school-to-work transitions is by looking at the time it 
takes to find one's first job. The analysis of the TIES Survey by Lessard-Phillips et al. (2012) revealed that in Strasbourg it took native-born descendants of immigrants from Turkey 3.56 mean months to find their first job while the comparison group took 3.38 months. The figures for Amsterdam were 2.10 mean months for the descendants of Turkish immigrants versus 1.70 for the comparison group. This is a very short time span in both cases and does not provide much variance when analyzing the time taken to start one's first job. I therefore focused on how the respondents' transitions had developed up until the time of the TIES Survey and the qualitative interviews, taking into account each respondent's entire (job) trajectory. Using both the TIES Survey and the qualitative interviews, I developed a typology for how the respondents' transitions developed during periods of activity and inactivity. Before I go into the findings in more detail, I will present typologies from the previous literature that informed the development of my typology.

\subsection{Transition Typologies in Previous Studies}

A few significant studies contain typologies of transition patterns that seek to explain the changing nature of youth transitions today. In the YOYO project, a comparative study of youth policy and participation in nine European countries, Plug and du-Bois Reymond (2003) created transition types based on the "complexity" of the transition pattern and the "length and direction of the transition period" (p. 108). YOYO research used qualitative data collected from young people who had signed up with youth centres, which offer assistance to young people to get their transitions back on track. Using biographical interviews, the researchers came up with six types: the first type is "smooth" transitions, in which young people made a smooth transition into the labour market following the institutional logic, while in "stagnant", "downward" and "institutionally repaired" transitions, they experienced unemployment, instability and even social exclusion (in the case of stagnant transitions). The authors also acknowledge a positive type of "alternative" transition whereby young people achieve upward mobility despite circumventing institutional logic, by applying active choices and strategies. Du-Bois Reymond had already described such young people as "trendsetters", (du Bois-Reymond 1998) who "aim to incorporate their personal lifestyles into their working lives" (p. 67). Even though the study was carried out in different countries, the authors did not draw any contextrelated conclusions and their conclusions paid little attention to social class and gender differences.

In their study of youth transitions in Bristol (UK), Bradley and Devadason (2008) developed a typology for young people's early labour market careers to determine whether youth transitions had become "de-standardized". This study focused on one setting, using a purposeful sampling strategy that took account of social class differences, gender and ethnicity. On the basis of qualitative interviews, the authors analyzed whether young people were experiencing unstable careers that fluctuated between periods of employment, unemployment and inactivity, or whether their 
career paths simply took a while to stabilize after graduation. Their typology contains four different types: "stickers", "shifters", "settlers" and "switchers". The first type, "stickers", refers to youngsters who had a specific career objective soon after leaving education. Stickers are not stuck in their job, but they settle in a career after shifting between a few jobs or statuses. In that sense, stickers are similar to the smooth transitions defined in the YOYO study. Bradley and Devadason's (2008) next category are "shifters"; young people who have intermittent periods of employment, training, unemployment, part-time jobs and travel and who have not yet settled into a long-term career or job. Although the authors emphasize that shifters might "actively make choices rather than reactively respond to labour market conditions" (p. 123), being a shifter also has negative connotations as an inability to settle down in a career may be due to labour market conditions rather than personal choice. Such transitions may be perceived as being similar to the "downward or stagnant transitions" in the YOYO study. In order to incorporate the element of "choice" or agency in their typologies, the Bristol study proposed two other types: "settlers" and "switchers". Settlers make a conscious decision to settle down in a career, sometimes accompanied by starting a family, while switchers may travel, return to education or embark on a new occupation. The switcher category is thus closest to the description of "alternative" transitions in the YOYO study. Taking account of the variance of social class, ethnicity and gender, the researchers found that women were more likely than men to be shifters and that married men were mostly found in sticker careers, which are more stable and traditional, although this did not apply to married women. The authors' explanation was that women's "traditional pattern of less stable market involvement" was contestably associated with having the "freedom to shift" (Bradley and Devadason 2008, p. 124) while acknowledging that the situation is more complicated for women. They found both highlyeducated and low-educated respondents in all of the pathways; hence they were not able to connect one type to a specific group. Based on the qualitative interviews they suggested that young people have somehow internalized today's labour market insecurities and perceive them as being part and parcel of their everyday reality (Bradley and Devadason 2008, p. 133).

Both studies interpret divergence from traditional or linear trajectories as having both negative and positive outcomes. They suggest why some young people experience shifts and non-traditional transitions while others don't, and how transition trajectories are configured by both structural settings and individual motivations. Although both studies "mentioned" ethnic minorities, they did not draw any conclusions in this regard due to sampling issues. Bradley and Devadason (2008) showed that ethnic minority youth were more represented in shifting careers. In the YOYO study, Plug and Du-Bois (2003) developed an additional category called "other" transitions in order to categorize cases which were unclear or had not yet developed. It was into this category that they placed a group of Roma girls from Portugal, who were "difficult to classify" because "they were subject to norms and structures that were fundamentally different from the standard model of youth transitions" (p. 121). The authors found it difficult to classify these girls' transitions since they seemed to be well-integrated within their "ethnic" community but experienced exclusion from 
"normal" modern educational and occupational careers as they got married very young and then dropped out of education and the labour market. However, in an early comparative study, Evans and Heinz (1994) show that, for some young women from a working class background in the UK, having a child and settling down was an active strategy to transition to adulthood in the face of stagnant careers, unemployment, or educational drop-out. Both the differences between countries when it comes to shaping transitions and the position of descendants of migrants are left unexplored by these prominent typologies.

Concentrating solely on the descendants of Algerian migrants in Lyon, Santelli (2012), pursued a different transition typology, one which was not informed by the debates on youth transitions. She concentrated on whether the descendants of migrants ended up reproducing their parents' initial conditions, using categories like "stable employed", "socially excluded", "insecure moving towards emancipation", "invisible proletarians" and "insecure graduates" (Santelli 2012). She didn't identify any dominant pattern and her sample was almost equally distributed among the five categories she had defined. Only two-fifths had achieved stable careers: those in stable transitions and the invisible proletariats, who had reproduced their fathers' conditions through clinging on to their jobs. Santelli's (2012) study is also inspiring in that it doesn't only focus on youngsters who were active in the labour market. From this brief look at studies on typologies, we can see that the studies conducted so far have either focused on group issues, addressing social class and gender differences but excluding those not active on the labour market, or have focussed solely on ethnic groups within one setting, without drawing any further conclusions about institutional structures.

Below I have constructed a transition typology for native-born descendants of immigrants from Turkey, taking into account both the institutional and social structures that shape their transitions both in and out of the labour market. In fact, ideas on what constitutes an acceptable transition appear to vary according to an individual's social milieu, habitus, access to forms of capital, and in particular, the structural and institutional settings in which their transitions are situated. In order to emphasize the importance of comparative structural differences, this chapter will first explore transition patterns in both cities among both the subject and comparison groups in the survey data. In looking at how the respondents' transitions had turned out, I will concentrate only on respondents who had left school and exclude those who were still studying. First, I will utilize the TIES data to map different labour market trajectories using a technique called latent class analysis. This quantitative method explores clusters in the data set in a descriptive way. The mechanisms behind these clusters will then be explored on the basis of the qualitative interviews. This will highlight the various complex structural and individual factors that interact to shape the transitions of native-born descendants of immigrants in both cities. 


\subsection{A New Transition Typology}

\subsubsection{Choice of Indicators}

To explore the different patterns of transitions in Amsterdam and Strasbourg, the TIES survey was analyzed using latent class analysis (LCA). Latent class analysis is an exploratory method for creating typologies without imposing an arbitrary typology. It categorizes respondents based on similarities of behavioural patterns or experiences, depending on their answers to selected categorical variables (McCuthcheon 1987; Yang 2006). The main objective is to cluster respondents into categories while identifying the variables that make them fit into these categories (Hagenaars and McCutcheon 2002). This makes it possible to identify a multidimensional discrete latent variable from a cross-classification of two or more categorical variables. The latent class analysis model is a form of factor analysis that uses categorical data.

I therefore applied LCA to the TIES data in order to derive empirical clusters. First, a number of categorical variables were selected that provided detailed information on the respondents' job histories. This sample was then limited to respondents who had left education and included both the native-born descendants of immigrants from Turkey and the comparison group. Separate analyses were conducted for currently active and inactive respondents and for respondents in Amsterdam and in Strasbourg.

The same set of variables was selected from the Amsterdam and Strasbourg TIES datasets to predict the latent class variables. Based on the literature review, we can talk about two main pathways: one follows smooth or traditional transitions, while the other shifts between different statuses. Both of these pathways might result from either personal motivations or structural conditions. Although the majority of respondents in the qualitative interviews emphasized that they wanted to achieve stable working arrangements, not all of them were able to do so. Therefore, the analysis of active respondents included variables that would inform the typology with regard to the stability of their current position. Fenton and Dermott (2006) analyzed the number of jobs young people had had since leaving school to explore labour market stability, controlling for years of schooling, job characteristics and education level to understand the nature of job switching. The analysis in this study takes the number of full-time jobs since leaving school, the number of years since schooling and the duration of the current employment as proxies for frequency of job change. It also includes whether respondents were offered permanent contracts or promotions as measures of job stability. Finally, it includes subjective appraisal and future plan variables, such as whether respondents were content with how their careers had turned out or their plans for the future in order to assess career pathway satisfaction. 
The analysis among inactive respondents includes both job seekers and people who were not looking for work. The variables for this group were chosen in an attempt to understand the nature of its members' status and if their unemployment was long-term. They include whether the inactive respondents had left school 5 years ago or longer; whether they had been unemployed for 12 months or longer; whether they had been employed previously, and whether they were also occupied with household tasks. An additional variable inquired regarding their plans for the future is whether they were planning on finding a job, studying or remaining inactive on the labour market. This variable assessed whether respondents were satisfied with their inactive status at the time of the interview and if they had clear-cut plans for the future.

Once these variables were put into the models, latent class analysis classified the respondents into different clusters. A model postulating three latent classes fits the data adequately for all four analyses (see Table 5.7 in the Appendix). This decision was based on both the best model fit statistics (AIC, BIC, and chi square significance levels) and the most sensible and substantive interpretation. Even if we do not initially know the actual size and nature of these classes, latent class analysis facilitates the inference of such clustering based on similarities in the responses (Hagenaars and Mccutcheon 2002; McCutcheon 1987). Furthermore, the analysis enables us to estimate the proportion of cases in each class, each individual's probability of belonging to a certain class, and the most prevalent classes. In the following section, we will elaborate on the results of our modelling.

Tables 5.1 and 5.2 illustrate the final distribution of clusters in both cities together with the prevalence of each class in the sample and the values of the variables estimating the clusters. The left-hand side lists the categorical variables used to predict the latent class variable. Next to each categorical variable are the estimated probabilities of these conditions occurring, which are conditional on latent class. Immediately below the latent classes, we can see the estimated relative size of each latent class.

\subsubsection{Active Transition Trajectories}

The analysis was run separately for Amsterdam and Strasbourg, using almost identical variables. Interestingly, similar clusters emerged with distinct distributions in each city. The most prevalent class of active respondents in Amsterdam is latent class two (stable transitions), while in Strasbourg both latent class one (shifting transitions) and latent class two (stable transitions) have similar proportions.

Active Latent Class 1: Early Stable Transitions Most respondents in the "early stable" category were still working in their first job and had managed to achieve a degree of stability. In Amsterdam, respondents had a higher probability of having been out of school for more than 5 years than in Strasbourg. In Amsterdam the members of this latent cluster had a high estimated probability of wanting to continue in 
Table 5.1 Conditional probabilities estimating transition trajectories for active respondents in Amsterdam and Strasbourg

\begin{tabular}{|c|c|c|c|c|c|c|}
\hline & \multicolumn{3}{|c|}{ Amsterdam } & \multicolumn{3}{|c|}{ Strasbourg } \\
\hline & \multicolumn{6}{|c|}{ Latent classes-active } \\
\hline & $\begin{array}{l}\text { 1. Early } \\
\text { stable }\end{array}$ & $\begin{array}{l}2 . \\
\text { Stable }\end{array}$ & \begin{tabular}{|l} 
Shifting \\
Shit
\end{tabular} & $\begin{array}{l}\text { 1. Early } \\
\text { stable }\end{array}$ & $\begin{array}{l}2 . \\
\text { Stable }\end{array}$ & $\begin{array}{l}3 . \\
\text { Shifting }\end{array}$ \\
\hline$\%$ & $28 \%$ & $55.3 \%$ & $16.7 \%$ & $27 \%$ & $36 \%$ & $37 \%$ \\
\hline $\mathrm{N}$ & 72 & 142 & 43 & 56 & 75 & 77 \\
\hline $\begin{array}{l}\text { More than } 5 \text { years since leaving } \\
\text { school }\end{array}$ & 0.42 & 0.64 & 0.47 & 0.08 & 1.00 & 0.59 \\
\hline $\begin{array}{l}\text { Working in current job for more than } \\
3 \text { years }\end{array}$ & 0.52 & 0.58 & 0.39 & 0.29 & 1.00 & 0.12 \\
\hline $\begin{array}{l}\text { Had other full-time jobs before } \\
\text { current job }\end{array}$ & 0.00 & 0.88 & 0.85 & 0.00 & 0.34 & 0.73 \\
\hline $\begin{array}{l}\text { Unemployed for longer than } \\
3 \text { months }\end{array}$ & 0.27 & 0.27 & 0.57 & 0.25 & 0.35 & 0.58 \\
\hline Has permanent contract in current job & 0.56 & 0.61 & 0.46 & 0.67 & 0.93 & 0.51 \\
\hline Has been promoted in current job & 0.39 & 0.42 & 0.21 & 0.26 & 0.38 & 0.08 \\
\hline Feels job matches education level & 0.79 & 0.93 & 0.39 & 0.73 & 0.78 & 0.82 \\
\hline $\begin{array}{l}\text { Feels career turned out worse than } \\
\text { expected }\end{array}$ & 0.26 & 0.00 & 0.76 & 0.29 & 0.50 & 0.39 \\
\hline \multicolumn{7}{|l|}{ Future plans: } \\
\hline Continue current job & 0.41 & 0.34 & 0.06 & 0.32 & 0.33 & 0.30 \\
\hline $\begin{array}{l}\text { Amsterdam: promotion, better job or } \\
\text { start own business/Strasbourg: } \\
\text { promotion or better job }\end{array}$ & 0.03 & 0.17 & 0.30 & 0.32 & 0.36 & 0.28 \\
\hline $\begin{array}{l}\text { Amsterdam: work less hours or } \\
\text { part-time/Strasbourg: start own } \\
\text { business }\end{array}$ & 0.33 & 0.33 & 0.48 & 0.19 & 0.06 & 0.26 \\
\hline Further training & 0.13 & 0.08 & 0.12 & 0.17 & 0.18 & 0.11 \\
\hline Other & 0.10 & 0.10 & 0.05 & 0.00 & 0.07 & 0.05 \\
\hline
\end{tabular}

Source: TIES Survey 2008

their current jobs. The transitions of respondents in this cluster most closely resemble the "traditional biographies" identified in previous studies (Evans and Heinz 1994), in which young people follow institutionally designed pathways from school to work and then stay in their first job.

Active Latent Class 2: Stable Transitions Despite having had a few jobs since leaving school, the respondents in the "stable" cluster had achieved the most stable positions. In both settings, they had the highest likelihood of being employed on a permanent contract, of having done the same job for more than 3 years and having been offered a promotion. The major contrast between the two settings was the satisfaction rates: while nearly all of the respondents in Amsterdam were satisfied with their careers, respondents in Strasbourg had the highest estimated probability of being dissatisfied compared to active latent classes 1 and 3. This finding is hard to 
Table 5.2 Conditional probabilities estimating transition trajectories of inactive respondents in Amsterdam and Strasbourg

\begin{tabular}{|c|c|c|c|c|c|c|}
\hline & \multicolumn{3}{|c|}{ Amsterdam } & \multicolumn{3}{|c|}{ Strasbourg } \\
\hline & \multicolumn{6}{|c|}{ Latent classes-inactive } \\
\hline & $\begin{array}{l}1 . \\
\text { Inactive }\end{array}$ & \begin{tabular}{|l}
. \\
Stagnant
\end{tabular} & \begin{tabular}{|l|}
3. \\
In-transition
\end{tabular} & \begin{tabular}{|l}
1. \\
Inactive
\end{tabular} & \begin{tabular}{|l} 
S. \\
Stagnant
\end{tabular} & $\begin{array}{l}3 . \\
\text { In-transition }\end{array}$ \\
\hline$\%$ & $40 \%$ & $44 \%$ & $16 \%$ & $33.3 \%$ & $29.7 \%$ & $37 \%$ \\
\hline $\mathrm{N}$ & 30 & 33 & 12 & 28 & 25 & 31 \\
\hline Had a paid job before & 0.87 & 1.00 & 0.69 & 0.40 & 0.92 & 0.78 \\
\hline $\begin{array}{l}\text { More than } 5 \text { years } \\
\text { since leaving school }\end{array}$ & 0.73 & 0.60 & 0.46 & 0.49 & 0.95 & 0.33 \\
\hline $\begin{array}{l}\text { Unemployed less than } \\
12 \text { months }\end{array}$ & 0.33 & 0.35 & 1.00 & 0.82 & 0.25 & 0.75 \\
\hline Homemaker & 0.60 & 0.34 & 0.00 & 0.20 & 0.66 & 0.00 \\
\hline \multicolumn{7}{|l|}{ Future plans: } \\
\hline Start working & 0.00 & 1.00 & 1.00 & 0.00 & 0.77 & 1.00 \\
\hline Further study & 0.53 & 0.00 & 0.00 & 0.6 & 0.05 & 0.07 \\
\hline
\end{tabular}

Source: TIES Survey 2008

interpret solely on the basis of the quantitative research, so it will be explored in more detail through the qualitative interviews. This latent class is similar to the "stable transitions" defined by Bradley and Devadason (2008) and the "smooth" transitions defined by the YOYO study (Walther et al. 2006), whereby young people have a few jobs before settling down in one.

Active Latent Class 3: Shifting Transitions Members of the "shifting" cluster had the lowest likelihood of having achieved permanent job contracts. They also had a high estimated probability of having left school more than 5 years ago. They had also the highest estimated likelihood of being unemployed longer than 3 months in both settings. Once more, there was a discrepancy with regard to satisfaction rates between the settings, and the qualitative interviews helped to interpret the mechanisms and motivations behind these shifting transitions. The estimated probability of being dissatisfied was higher in Amsterdam than in Strasbourg. This latent class resonates with the "shifters" identified by Bradley and Devadason (2008): young people who had not been able to pursue a stable pathway in their labour market careers.

\subsubsection{Inactive Transition Trajectories}

The inactive respondents were grouped according to the duration of their unemployment and plans regarding employment in the future (see Table 5.2). 
Inactive Latent Class1: Inactive Although the characteristics of the "inactive" cluster differ distinctively between the settings, there is one overlapping characteristic: respondents in this group, both in Amsterdam and Strasbourg, are not planning to work in the near future. In Amsterdam, this group had a high probability of having been out of school for longer than 5 years and unemployed for longer than 12 months. Respondents from this group in Strasbourg were less likely to have been unemployed for longer than 12 months. Members of this cluster in Amsterdam also had a higher estimated likelihood of being homemakers than their peers in Strasbourg. These inactive respondents most closely resemble what Plug and du Bois-Reymond (2006) labelled "unknown/other" transitions, whereby young people left the labour market after getting married.

Inactive Latent Class 2: Stagnant Members of the "stagnant" cluster had a high estimated probability of having been unemployed for longer than 12 months while actively seeking work. Young people in this cluster had a high likelihood of having worked before. The distinction between the two settings was that the respondents in Strasbourg also had a high estimated probability of being homemakers. Previous studies have defined stagnation as shifting between unemployment, employment, and training without any overall improvement in career stability (Evans and Heinz 1994; Plug and Bois-Reymond 2006). However, such a judgement cannot be made for this cluster on the basis of the quantitative findings alone. These respondents' transitions were termed stagnant due to extended periods of unemployment despite their willingness to work. The mechanisms and motivations underlying this will be explored through the qualitative profiles.

Inactive Latent Class 3: In-transition The "in-transition" group was characterized by having been out of school for less than 5 years and expressing a willingness to work. Hence, their condition is interpreted as being transitory compared to other profiles who had a higher likelihood of having been out of school for longer. This group also had a higher likelihood of short-term unemployment: the majority had a high estimated probability of being unemployed for less than 12 months. This group had no probability of being homemakers and all were willing to work. The members of this class were either new to the labour market or between jobs at the time of the interview. The transitions of this group could just as well be described as "shifting" or "stable", as they may have been just changing jobs to forward their careers. This cluster will be better understood by examining the qualitative interviews, which will reveal whether they had extended or persistent periods of unemployment. 


\subsubsection{Distributions of the Latent Classes by Immigrant Background, Gender, Education Level, Age and Job Status}

Tables 5.3 and 5.4 illustrate the estimated number of respondents from both the focus and control groups falling under the identified latent classes. They also showed that early stable and stable transitions (in total for both groups) were more prevalent in Amsterdam than Strasbourg. Tables 5.3 and 5.4 show that, among the active trajectories, the native-born descendants of Turkish immigrants were more represented in shifting transitions both in Amsterdam and Strasbourg, though to varying degrees: in Amsterdam, 24\% had shifting transitions compared to $13 \%$ in the comparison group, while, in Strasbourg, these figures were $45 \%$ and $27 \%$ respectively.

Tables 5.3 and 5.4 show the distribution of the latent classes by gender. Female native-born descendants of immigrants are more likely to have inactive trajectories in Amsterdam than in Strasbourg. However, in Amsterdam females active in the labour market are more likely to have early stable transitions and less likely to have shifting transitions than males, who have the highest incidence of shifting transitions in Amsterdam (see Table 5.3).

A covariate which could also be crucial to understanding group differences is the distribution of education level across the latent classes. Previous studies have highlighted that instability is not limited to less-educated groups but is also increasingly experienced by those with higher education qualifications (Bradley and Devadason 2008; Fenton and Dermott 2006). Table 5.5 illustrates the distribution

Table 5.3 Distribution of active and inactive latent classes by sample group and gender in Amsterdam

\begin{tabular}{|c|c|c|c|c|c|c|c|}
\hline & \multicolumn{7}{|c|}{ Amsterdam } \\
\hline & \multicolumn{3}{|c|}{$\begin{array}{l}\text { Descendants of immigrants } \\
\text { from Turkey (TR) }\end{array}$} & \multicolumn{3}{|c|}{ Comparison group (CG) } & \multirow{2}{*}{\begin{tabular}{|l} 
TR + CG \\
Total
\end{tabular}} \\
\hline & Male & Female & Total & Male & Female & Total & \\
\hline \multicolumn{8}{|l|}{ Active classes: } \\
\hline Early stable & $25 \%$ & $36 \%$ & $30 \%$ & $29 \%$ & $25 \%$ & $27 \%$ & $28 \%$ \\
\hline Stable & $46 \%$ & $45 \%$ & $46 \%$ & $56 \%$ & $65 \%$ & $60 \%$ & $55 \%$ \\
\hline Shifting & $29 \%$ & $19 \%$ & $24 \%$ & $15 \%$ & $10 \%$ & $13 \%$ & $17 \%$ \\
\hline Total $(\mathrm{N})$ & $\begin{array}{l}100 \% \\
(48)\end{array}$ & $\begin{array}{l}100 \% \\
(42)\end{array}$ & $\begin{array}{l}100 \% \\
(90)\end{array}$ & $\begin{array}{l}100 \% \\
(87)\end{array}$ & $\begin{array}{l}100 \% \\
(80)\end{array}$ & $\begin{array}{l}100 \% \\
(167)\end{array}$ & $\begin{array}{l}100 \% \\
(257)\end{array}$ \\
\hline \multicolumn{8}{|c|}{ Inactive classes: } \\
\hline Inactive & $20 \%$ & $48 \%$ & $41 \%$ & $50 \%$ & $33 \%$ & $38 \%$ & $40 \%$ \\
\hline Stagnant & $60 \%$ & $36 \%$ & $42 \%$ & $50 \%$ & $50 \%$ & $50 \%$ & $44 \%$ \\
\hline $\begin{array}{l}\text { In-transition } \\
\text { (unemployed) }\end{array}$ & $20 \%$ & $16 \%$ & $17 \%$ & $0 \%$ & $17 \%$ & $13 \%$ & $16 \%$ \\
\hline Total $(\mathrm{N})$ & $\begin{array}{l}100 \% \\
(15)\end{array}$ & $\begin{array}{l}100 \% \\
(44)\end{array}$ & $\begin{array}{l}100 \% \\
(59)\end{array}$ & $\begin{array}{l}100 \% \\
(4)\end{array}$ & $\begin{array}{l}100 \% \\
(12)\end{array}$ & $\begin{array}{l}100 \% \\
(16)\end{array}$ & $\begin{array}{l}100 \% \\
(75)\end{array}$ \\
\hline
\end{tabular}

Source: TIES Survey 2008 
Table 5.4 Distribution of active and inactive latent classes by sample group and gender in Strasbourg

\begin{tabular}{|c|c|c|c|c|c|c|c|}
\hline & \multicolumn{7}{|c|}{ Strasbourg } \\
\hline & \multicolumn{3}{|c|}{$\begin{array}{l}\text { Descendants of immigrants } \\
\text { from Turkey (TR) }\end{array}$} & \multicolumn{3}{|c|}{ Comparison group (CG) } & \multirow{2}{*}{$\begin{array}{l}\mathrm{TR}+\mathrm{CG} \\
\text { Total }\end{array}$} \\
\hline & Male & Female & Total & Male & Female & Total & \\
\hline \multicolumn{8}{|l|}{ Active classes: } \\
\hline Early stable & $31 \%$ & $20 \%$ & $25 \%$ & $32 \%$ & $27 \%$ & $29 \%$ & $27 \%$ \\
\hline Stable & $24 \%$ & $36 \%$ & $30 \%$ & $47 \%$ & $41 \%$ & $44 \%$ & $36 \%$ \\
\hline Shifting & $45 \%$ & $44 \%$ & $45 \%$ & $21 \%$ & $31 \%$ & $27 \%$ & $37 \%$ \\
\hline Total (N) & $\begin{array}{l}100 \% \\
(58)\end{array}$ & $\begin{array}{l}100 \% \\
(61)\end{array}$ & $\begin{array}{l}100 \% \\
(119)\end{array}$ & $\begin{array}{l}100 \% \\
(38)\end{array}$ & $\begin{array}{l}100 \% \\
(51)\end{array}$ & $\begin{array}{l}100 \% \\
(89)\end{array}$ & $\begin{array}{l}100 \% \\
(208)\end{array}$ \\
\hline \multicolumn{8}{|c|}{ Inactive classes: } \\
\hline Inactive & $21 \%$ & $35 \%$ & $32 \%$ & $42 \%$ & $33 \%$ & $37 \%$ & $33 \%$ \\
\hline Stagnant & $21 \%$ & $35 \%$ & $32 \%$ & $8 \%$ & $40 \%$ & $26 \%$ & $30 \%$ \\
\hline $\begin{array}{l}\text { In-transition } \\
\text { (unemployed) }\end{array}$ & $57 \%$ & $30 \%$ & $37 \%$ & $50 \%$ & $27 \%$ & $37 \%$ & $37 \%$ \\
\hline Total $(\mathrm{N})$ & $\begin{array}{l}100 \% \\
(14)\end{array}$ & $\begin{array}{l}100 \% \\
(43)\end{array}$ & $\begin{array}{l}100 \% \\
(57)\end{array}$ & $\begin{array}{l}100 \% \\
(12)\end{array}$ & $\begin{array}{l}100 \% \\
(15)\end{array}$ & $\begin{array}{l}100 \% \\
(27)\end{array}$ & $\begin{array}{l}100 \% \\
(84)\end{array}$ \\
\hline
\end{tabular}

Source: TIES Survey 2008

Table 5.5 Distribution of education level across the latent classes

\begin{tabular}{l|l|l|l|l|l|l}
\hline & $\begin{array}{l}\text { Early } \\
\text { stable }\end{array}$ & Stable & Shifting & Inactive & Stagnant & In-transition \\
\hline $\begin{array}{l}\text { Amsterdam } \\
\text { VMBO }\end{array}$ & $16 \%$ & $12 \%$ & $28 \%$ & $50 \%$ & $39 \%$ & $25 \%$ \\
\hline $\begin{array}{l}\text { HAVO/VWO/ } \\
\text { MBO }\end{array}$ & $28 \%$ & $32 \%$ & $42 \%$ & $47 \%$ & $30 \%$ & $25 \%$ \\
\hline HBO/Uni. & $56 \%$ & $56 \%$ & $30 \%$ & $3 \%$ & $30 \%$ & $50 \%$ \\
\hline Total & $\begin{array}{l}100 \% \\
(72)\end{array}$ & $\begin{array}{l}100 \% \\
(142)\end{array}$ & $\begin{array}{l}100 \% \\
(43)\end{array}$ & $\begin{array}{l}100 \% \\
(30)\end{array}$ & $\begin{array}{l}100 \% \\
(33)\end{array}$ & $\begin{array}{l}100 \% \\
(12)\end{array}$ \\
\hline $\begin{array}{l}\text { Strasbourg } \\
\text { College }\end{array}$ & $11 \%$ & $9 \%$ & $14 \%$ & $36 \%$ & $40 \%$ & $32 \%$ \\
\hline CAP/BEP & $16 \%$ & $27 \%$ & $26 \%$ & $7 \%$ & $44 \%$ & $23 \%$ \\
\hline Bac. Diploma & $18 \%$ & $19 \%$ & $26 \%$ & $29 \%$ & $12 \%$ & $26 \%$ \\
\hline BTS/Uni/CPGE & $55 \%$ & $45 \%$ & $34 \%$ & $29 \%$ & $4 \%$ & $19 \%$ \\
\hline Total & $\begin{array}{l}700 \% \\
(56)\end{array}$ & $\begin{array}{l}100 \% \\
(75)\end{array}$ & $\begin{array}{l}100 \% \\
(77)\end{array}$ & $\begin{array}{l}100 \% \\
(28)\end{array}$ & $\begin{array}{l}100 \% \\
(25)\end{array}$ & $\begin{array}{l}100 \% \\
(31)\end{array}$ \\
\hline
\end{tabular}

Source: TIES Survey 2008

of educational attainment across our latent classes and all respondents. Of those in shifting transitions, 30\% in Amsterdam and 34\% in Strasbourg have tertiary degrees. In both settings, the majority of those in stable or early stable transitions hold tertiary degrees, while those in inactive and stagnant transitions predominantly hold lower qualifications. 
Another approach is to check the distribution of latent classes across education levels. Table 5.8 in Appendix in this chapter shows that the majority of tertiary degree holders were in either early stable or stable transitions in both settings. However, the distributions were different in each setting; while $84 \%$ of tertiary degree holders in Amsterdam achieved either stable or early stable transitions, this figure was only 51\% in Strasbourg. In Amsterdam, the majority of those with a vocational diploma achieved early stable or stable transitions $(66 \%)$, whereas in Strasbourg 35\% of vocational diploma holders achieved a form of stability. On the contrary in Amsterdam those who dropped out of VMBO had the highest rates of inactive or stagnant transitions compared to other diploma holders. This descriptive comparison confirms our discussion of educational credentials and their returns in Amsterdam; those who hold tertiary degrees and vocational degrees have higher likelihood showing early stable and stable transitions in Amsterdam compared to Strasbourg. When compared by education level, young people with higher degrees in Strasbourg had less stable transitions compared to their peers in Amsterdam.

Finally, the distribution of latent classes across age groups shows that in all age groups (18 to 22, 23 to 29, 30+), respondents in Amsterdam were more likely to have experienced either early stable or stable transitions; hence gaining stability begins at an earlier age and it is almost equally distributed across age group (see Table 5.9 in Appendix in this chapter). However, in Strasbourg, none of the respondents aged between 18 and 22 had stable transitions, although a significant proportion were found in early stable transitions. Stability was more likely in older age groups. ${ }^{1}$

I have also checked what kind of jobs the respondents were referring to in these typologies. In order to highlight what kind of jobs we are talking about when referring to stable or early stable careers among the active profiles, the latent class variable was cross-tabbed with the ISCO codes. ${ }^{2}$ Accordingly among the group stable

\footnotetext{
${ }^{1}$ The descriptive trends were also checked with multivariate analysis. Binary logit models were used to estimate group membership for each cluster relative to being in other two clusters. The aim was to see whether being in one cluster is determined by having immigrant parents, gender, age, education level or parents' education level. A few trends were observed. In the final models, age turned out to be the most significant determinant of having a stable career in both Amsterdam and in Strasbourg: the likelihood of being in a stable career increased along with age. In Amsterdam having a higher education degree (compared to a lower secondary qualification or less) was significantly negatively associated with having a shifter transition rather than an early stable or stable transition. Nevertheless due to the small case numbers these models are not presented in the current analysis. An analysis with a larger data set could provide a more robust analysis incorporating latent class variables.

${ }^{2}$ In social stratification research, job titles and occupational status are considered the primary measures of social position (Ganzeboom and Treiman 1996). The ISCO-08 codes are based on the skills needed for an occupation and the employment sector. The TIES dataset contains detailed job descriptions given by respondents about tasks performed in their current and previous jobs and the ISCO codes attached to these jobs. The ISCO codes are not a hierarchical occupational status scheme such as EGP codes or ISEI. However, they provide a descriptive tool to illustrate the different positions the young people had held at work. ISCO-08 categories are managers (chief executives, senior officials, administrative/ commercial/ services/ production/ retail managers) excluding small shop owners and entrepreneurs, professionals (science, engineering, health, teaching, busi-
} 
transitions in Amsterdam, only 5\% of native-born descendants of immigrants from Turkey worked in managerial positions compared to $15 \%$ of the comparison group. Of the other descendants of immigrants from Turkey in stable transitions, $24 \%$ were technicians and associate professionals, 24\% were clerical workers, and $20 \%$ worked in the service sector (including small shop owners and entrepreneurs). In Strasbourg, among the native-born descendants of Turkish immigrants, only $7 \%$ of the early stable transition holders reported having a managerial position, compared to $8 \%$ of the comparison group. Once more, the largest group of native-born descendants of immigrants from Turkey with stable transitions were plant and machine operators in the manufacturing sector (31\%). Among the comparison group, $13 \%$ of stable transition holders held managerial jobs and $46 \%$ were in professional occupations. This occupational status scheme illustrates that achieving stability doesn't necessarily mean that young people hold managerial or professional positions. As we will see in the qualitative interviews, some respondents were "fixated" in deadend jobs with no opportunity for promotion, whereby some were motivated to leave their jobs, while others decided to remain.

The findings from the quantitative analysis uncovered trends both in relation to the contexts and the groups. First of all, the distribution of transition typologies varied between the settings. When no distinction was made between the native-born descendants of Turkish immigrants and the comparison group, we observed that a greater number of active respondents demonstrated shifting transitions in Strasbourg (37\%) than in Amsterdam (17\%). Those with either early stable or stable transitions were still the largest group in both settings but were more numerous in Amsterdam $(83 \%)$ than in Strasbourg (63\%). Hence respondents from both groups in Amsterdam had a higher probability in achieving in stable and early stable careers compared to those in Strasbourg. When we look at the comparative distributions across groups, we see a higher incidence of shifting careers among the native-born descendants of immigrants from Turkey than among the comparison group in both cities, but once more, this figure is higher in Strasbourg. Among the inactive profiles, there are more native-born descendants of immigrants from Turkey in both settings. With regard to gendered distributions, we have seen that female descendants of migrants were more likely to have inactive careers compared to male descendants of Turkish, but when they were active they were to be found in greater numbers in early stable and stable careers (combined) than the males, especially in Amsterdam. In Strasbourg,

ness, administration, IT and legal, social and cultural professionals), technicians and associate professionals (technicians and science engineering, health, teaching, business, administration, IT and legal, social and cultural associate professionals), clerical support workers (general, keyboard, customer, numerical clerks and other clerical support workers), service and sales workers (personal service, sales, care, protective services workers), craft and related trades (builders and related trades workers, excluding electricians, metal, machinery and related trades workers, handicraft and printing workers, electricians, food processing and garment, craft and related trades workers), plant and machine operators and assemblers (machine and plant operators, assemblers, drivers and mobile operators), elementary occupations (cleaners and helpers as well as unskilled agricultural workers, street workers) (http://www.ilo.org/public/english/bureau/stat/isco/docs/resol08.doc). 
male and female descendants of migrants were almost equally represented in shifting careers among the respondents active in the employment market. $35 \%$ of the Turkish origin women were in inactive careers, compared to $21 \%$ of the men. $70 \%$ of the females had either inactive or stagnant careers in Strasbourg. The distribution of transition trajectories also varied according to respondents' educational careers. The majority of the stable and smooth transition holders in both Amsterdam and Strasbourg possessed tertiary education diplomas. However, a considerable number of highly-educated respondents had a shifting status, in line with previous findings that shifter careers are not only found among the less educated (Fenton and Dermott 2006). Nevertheless, those respondents who dropped out of lower secondary education without a minimum qualification (VMBO or collège certificate) experienced the highest rates of inactive or shifting transitions both in Amsterdam and Strasbourg. This finding suggests that "shifting transitions" are not desirable "alternatives" but more inevitable outcomes of stagnation. Age also turned out to be a significant marker as the likelihood of having a stable career increased with age in both cities. The next section will focus on the transition narratives of the respondents in the qualitative interviews, who were also sampled from the TIES survey. This data will help to unravel the mechanisms behind their transition processes and flesh out the transition typologies produced by the quantitative analysis.

\subsection{Refining the Transition Typologies: Qualitative Profiles}

Each of the qualitative interviews has been analyzed to explain how it corresponds to the typology. Clearly, the qualitative interviews generated deeper insights into respondents' employment trajectories and their subjective evaluations of their experience. Respondents explained in detail why they considered or refrained from changing their jobs; why they were satisfied or dissatisfied with how their careers had turned out; how they evaluated labour market conditions and the impact they had on their transitions; the extent to which they embraced flexibility and what they thought of all this. Profiles from the qualitative interviews are provided below in Table 5.6.

First, I will define the early stable and stable transition types. As they are closely related to each other, their differences will be unravelled and their similarities highlighted by examining how they interact with the different structures in each setting.

Table 5.6 Qualitative profiles by transition trajectories for those who left school

\begin{tabular}{l|l|l}
\hline & $\begin{array}{l}\text { Amsterdam } \\
\text { TR }\end{array}$ & $\begin{array}{l}\text { Strasbourg } \\
\text { TR }\end{array}$ \\
\hline Early stable & 7 & 5 \\
\hline Stable & 3 & 3 \\
\hline Shifting & 3 & 5 \\
\hline Inactive & 2 & 4 \\
\hline Stagnant & 1 & 1 \\
\hline In-transition & 3 & 2 \\
\hline
\end{tabular}


Secondly, shifting transitions will be presented. Since the qualitative interviews provided rich information on labour market experiences and orientations, those who experienced "in-transition" careers are also considered as belonging to this category. Next, shifting transitions will be compared with "stagnant" careers. Finally, we will concentrate separately on inactive careers. Most members of this group in the qualitative sample are young women who had withdrawn from labour market activity to become homemakers.

\subsubsection{Early Stable and Stable Transitions}

Our quantitative analysis categorized respondents as demonstrating early stable transitions if they had remained in their first job after leaving school, and as having stable transitions if they had had a few jobs (but not many) before settling in one. In our qualitative interviews, we categorized our respondents as having early stable or stable transitions based on their employment history and their motivation for remaining in their jobs.

These two transition typologies are reminiscent of the smooth and traditional transitions defined in the literature (Evans and Heinz 1994; Plug and Bois-Reymond 2006). In that sense these young people followed institutionally defined pathways of going straight from school to a job related to their studies, especially in Amsterdam. The former group continued to work for their internship company after graduation (early stable) or found a job via contacts they had made during their studies. In contrast, those in stable transitions had taken longer to find a job or had had a few jobs before finding a steady job.

The interviews revealed that these young people wished to remain in their jobs for a number of reasons: some were afraid of unemployment due to the economic crisis, and responsibilities such as marriage, children and mortgage payments were also mentioned as incentives. Those in stable transitions were also motivated by the memory of their prior shifting careers and a desire to settle in at their job.

Below we will look at two profiles that best illustrate the salient details of these forms of transitions: the first is of Tülin from Amsterdam, who experienced an early stable transition, and the other is of Deniz from Strasbourg, who was in a stable transition.

\section{Early Stable Transitions: Tülin, 25, Doctor's Assistant in a GP's Office, Amsterdam}

Tülin was born and raised in Amsterdam. At the time of our interview she was living in the north of the city together with her husband and her 6-month-old baby boy. Tülin's father had moved to the Netherlands at the age of 17, along with his father who was a guest worker. Tülin's father had a primary school diploma from Turkey, and acquired some proficiency in Dutch. He did all sorts of unskilled jobs, such as 
cleaning and newspaper delivery. At the time of the interview, he was working as a taxi driver along with many of her other relatives. Her mother came to the Netherlands to marry her father and had never worked outside of the house. Tülin was their eldest child and had two younger brothers.

Tülin talked positively about her education. She was a well-behaved pupil who got on with her teachers and achieved average grades. However, she was often unable to concentrate at primary school, as her mother was ill, and after getting a low CITO score, she was advised to follow a vocational track. Tülin had wanted to attend the general academic track, but her grades were not good enough. Her teachers tried to comfort her by saying she could always pursue further education in the future.

Gender influences could be observed in Tülin's choice of vocational subject (Gaskell 1992). She had always dreamed of becoming either a flight attendant or a nurse as she liked the atmosphere in airports and in hospitals. Unsure of which to study, she attended career information days where she discovered that working as a flight attendant would mean learning several foreign languages and working long, irregular hours. She decided that this profession would be too arduous and difficult to combine with family life, something she also aspired to. She therefore did the healthcare track at vocational school and upper secondary education and became an assistant to a general practitioner.

Tülin said that although her parents did "not get involved" in her education, they nevertheless supported her decisions. Nobody else in her family had ever had such a job and Tülin's mother had neither worked nor learnt to speak fluent Dutch. As her father had not offered her much guidance, she had had to steer her own course. Her parents supported her decision to become a doctor's assistant rather than a stewardess, as they considered this a more suitable profession for a woman.

During her post-secondary vocational training, Tülin conducted two internships that proved instrumental to her future career choices. The first was in an administrative office at a hospital, where she answered the telephone and recorded patient information. The second was as a doctor's assistant in a GP's practice, where, in addition to administrative duties, she also performed minor nursing tasks, such as taking blood samples and giving vaccinations. She enjoyed this internship much more as it allowed her to use skills she had learnt at school. Both internships provided Tülin with cultural capital comprised of insider information about labour market expectations and occupation-specific tasks.

After Tülin finished her training, she opted to stay on for another year to obtain her MBO N-4 diploma, as this provided access to vocational tertiary education (HBO). In terms of financial capital, Tülin's father earned enough to support her education and she did not have to take many student jobs. At one point she was able to stop working to concentrate on her studies. She eventually decided to pursue her long-delayed ambition to enter higher education. With a close friend, she visited open days organized by higher education institutions and they both enrolled in a social work (maatschappelijk werk) course. However, this study did not fulfil Tülin's expectations, and she dropped out 2 months later to avoid having to repay her student loan. 
As Tülin had not enjoyed her internship experience in the hospital, she started looking for a job as a GP's assistant in Amsterdam. After about 2 months, she applied for a post and was called in for an interview. She was up against other Dutch women, who were older and more experienced, but thinks that she got the job because she was younger and looked more open to learning and adjusting to the workplace. At the time of the interview, she had been working there for 3.5 years and had secured a permanent contract. The year after she started her job, she got married to a Turkish immigrant who had arrived in the Netherlands at the age of 15 and was working nights as a taxi driver with her father. They found an apartment in a social housing complex in North Amsterdam, and she became pregnant the following year. After her son's birth she worked part-time while he adjusted to day-care.

Tülin was quite satisfied with her job. She liked her work environment and said that the doctors and most of her colleagues were friendly. Nevertheless, she had experienced a few distressing incidents, especially after announcing her decision to wear a headscarf at work. Tülin had not worn a headscarf when she applied for the job. She had started wearing a headscarf in lower secondary school (VMBO) at the age of 14, but took it off again when she was 18 as she did not feel ready to take this step. She decided to wear it again 1 year after she started working. She emphasized that her workplace was open to such practices as her Moroccan colleague already wore a headscarf. Nevertheless, once she made up her mind, she informed her colleagues beforehand to avoid potential reactions when they saw her with a headscarf the next day.

TÜLIN: Where I work, they really value one's physical appearance and how one looks. I have long, black, curly hair and you know it is different from short blond hair, so they really like that and they would always compliment me. Back then everything was pleasant and happy... until I decided to wear a headscarf.

INTERVIEWER: Is there anyone else wearing a headscarf in the workplace?

TÜLIN: Yes, yes there is one; a Moroccan girl. She also decided to wear a headscarf after she started working and she has been (working) there for over 10 years now. I mean, they think that we put on the headscarf when we are about to get married or after we get married because our husbands want us to. They have this stuck in their brains. Anyways, once I had decided, I started telling them, "I am considering wearing a headscarf," so they wouldn't get a shock the next day when they saw me wearing it and wouldn't react badly. Because, you know, I have this thing; I just can't keep my thoughts to myself; if I am confronted with something I react very harshly. But I also didn't want to experience this or any kind of confrontation at work. Then I was ready; I went with the headscarf. My close friends from work [the Moroccan lady and another Dutch colleague] already knew.

However, other people's reactions were not as easy-going as she had hoped. Some of the doctors made fun of her, while others questioned her decision. One doctor confronted her during the weekly workplace meeting, but later apologized for her behaviour. Eventually, her colleagues got used to her new look.

Tülin wanted to stay in her job, even though it did not offer any prospects for promotion. She enjoyed the work environment, the work itself and the flexible working hours, which were important to her since becoming a mother. However, she felt that she wouldn't have been hired if she had worn a headscarf to the interview. 
Considering the difficulties of getting her headscarf accepted in a work environment where she was already well-liked and trusted made her question how easy it would be for her to find another job. Hence, Tülin's unwillingness to risk a change and her desire to maintain a stable position and hold on to her job was prompted both by positive and negative experiences.

Tülin also explained that the conflict over her headscarf was an issue of physical appearance rather than of religiosity. In fact, she reported that her colleagues thought it was a shame that she had covered "such beautiful hair". She rejected this, saying "I hadn't shaved my head; I was just covering it, and it was not their business what I do with my hair!" The importance of physical appearance in the workplace was brought up repeatedly by many respondents. Many realized after entering the workforce that their looks were crucial to gaining acceptance in the workplace. Young people in both France and the Netherlands talked about the importance of their name and appearance at work. Both gender and religion played an important part in shaping Tülin's decision to stick at her job: young Muslim women wearing a headscarf often reported negative labour market experiences in both settings, although this was harsher in Strasbourg as was discussed in Chap. 3.

\section{Stable Transition: Deniz, 28, Administrative Worker in a Notary's Office, Strasbourg}

Deniz was born and raised in Strasbourg. Her father was a labour migrant who later worked as a house painter on construction sites. Her mother was a homemaker and had never worked. Deniz had one older sister and a younger brother and sister. The family lived in a social housing complex situated in a majority-minority neighbourhood (quartier) of Strasbourg.

Deniz persevered throughout her education and studied hard to achieve her aim to attend higher education. Her parents were fully supportive of her efforts and even though they did not possess the cultural or social capital to provide her with instrumental guidance or contacts, they created an emotionally supportive environment (Reay 2004). After lyceum, she decided to study at a vocational college (BTS) rather than a (non-selective) university. It did not even cross her mind to apply to a prestigious university (grande école). Vocational colleges required only 2 years of training and Deniz felt that they provided clear occupational trajectories and better job opportunities, while university would take 4 years and seemed a more demanding and uncertain pathway into the labour market. Deniz thus didn't feel confident enough to risk going to university. She majored in administration and secretarial studies as she thought that this would provide her with the most flexibility and the largest range of job options.

After graduating, Deniz embarked upon a serious job search. As her family had no computer at home, she registered with employment agencies and went there every day to ensure she was the first person they contacted if a vacancy came up. After 6 months, she found a 4-month administrative position at a high school to 
replace a colleague who had gone on maternity leave. Even though this post meant a 2-h bus commute every day, she accepted it to gain work experience.

After 4 months Deniz was back on the job market. She continued to visit the employment agencies and would also go to her best friend's house to use her computer and internet. Her friend's parents were immigrants from Morocco. One day, her friend's older sister, who was a law student in Strasbourg University, informed her of a position in a notary's office that a French classmate had told her about. This experience illustrates the strength of the weak ties postulation (Granovetter 2005), which argues that weak connections with majority groups provide more resources in labour markets than strong ties within a closer circle. This job was not advertised in the newspaper or by employment agencies, but was spread by a few law students through word of mouth. That night, Deniz phoned the notary to make an appointment first thing Monday morning. At the interview, she was told that this job was once more a temporary, four-month position to replace a colleague on maternity leave. This did not deter Deniz and she was accepted.

This job was a much more challenging position than her previous position. As a notary's secretary, she had to learn many new rules and regulations. Furthermore, she found herself in a stressful and demanding working environment with colleagues who were neither friendly nor helpful. In her first months, her colleagues asked her to do all sorts of errands and legwork that were not part of her job description. Once more, Deniz demonstrated her perseverance and willingness to work hard. Her determination did not go unnoticed, and, 2 months later, her boss offered her a full-time position, followed by a permanent contract (embouché) 1 year later. Nevertheless, she still felt challenged, saying that she had been learning the tricks of the trade since day one. For example, soon after she started working she realized that one's physical appearance was crucial to success in the workplace. After some nasty comments from her bosses, she adjusted her looks and clothing.

Her experience in the solicitor's firm also convinced Deniz that contrary to what she had been taught at school, not everybody had equal opportunities on the labour market.

DENIZ: You know, I never cared about discrimination; I never gave it any thought. I thought it didn't exist - at least before I started working here or entered the labour market. Our teachers always told that us that if you want to go high and make it in the labour market, your qualifications hold the key to success. But my labour market experience proved that even if you have qualifications, they are not enough ... My boss told me this, I heard it with my own ears. He asked me, "Why do you think I placed you in the back desk and not in the front desk?" This was three weeks after I started working here. First I cried a lot and I couldn't reply, you know, I couldn't say anything. And then he said "I am not racist, but you have to understand I cannot risk my clients seeing you when they come here." I mean you see where my room is? It is located exactly opposite the lift. So what diploma? I mean I was still lucky that they gave me a job, but would you be surprised if they took someone French instead?

These worries made Deniz stick at her job and not try her chances elsewhere. She had been doing the same job for 4 years and had secured a permanent contract. Her job was still stressful and demanding and she still had a hard time getting herself accepted by her colleagues, but her permanent contract meant that she had stopped 
caring so much. In time, her bosses had begun to invite her to social events, though selectively. She still felt out of place on occasions such as dinners with customers or parties, where other people drank alcohol and she didn't. Yet she also felt more equipped to "manage" these occasions. Her ambition was to get promoted to the position of clerc de notaire; the highest-ranking solicitor's secretary. Although she feared that her lack of legal training would stand in her way, she had confidence in her potential and abilities. The fact that she was handling the sale of a $€ 30$ million property deal was proof of her boss's faith in her.

In order to work her way up through the company, Deniz had to be extremely dedicated and hardworking, making sure to avoid mistakes. She had started off just above the minimum wage (bruto SMIC) of around $€ 1400$, but this had been increased to around $€ 1800$ net. She was quite happy with her current salary, and was planning on buying an apartment with her savings. In the initial interview, Deniz's main concern was marriage, as she was 27 and still single. The age of marriage was quite young in Strasbourg and most of her friends were already married with children. She described postponing marriage as the greatest price she had paid for her successful career, and worried that she might miss out on having a family. In the follow-up interview 1 year later, she told me that she had been passed over for promotion to clerc de notaire for another colleague with a law diploma. She was very disappointed and felt betrayed, as one of her bosses had promised her the position. Yet she still did not plan on changing her job. Instead she had modified her behaviour, exerting herself less at work. She said that she now stuck to her working hours and left at 17:00 like the other employees. She no longer made extraordinary effort to prove herself.

These two profiles are revealing in terms of attitudes towards stability and transition. Tülin's case can be taken as a typical example of a smooth or traditional transition (Evans and Heinz 1994), leading to a stable labour market outcome as well as a smooth entry into matrimony and starting a family. Even though Tülin tried a few options during her vocational tertiary education, it is hard to describe this as a form of shifting or risk taking, as this is becoming increasingly common among many vocational track students. Moreover, after her brief foray into higher education, Tülin returned to her institutionally designated pathway.

The juxtaposition of Deniz's and Tülin's cases also illustrates the role that options for promotion play in young people's orientations. For those with vocational degrees, low occupational status and meagre promotion prospects, a permanent contract is a desirable end result. The only other option is to start their own business. Deniz also had other incentives to stay in her job: first of all, it had taken her nearly 2 years to find a full-time position. This was largely due to the major differences in labour market conditions between Amsterdam and Strasbourg. Even though Tülin only had a vocational diploma, she was able to make a much smoother entry into labour market than Deniz, who had a tertiary vocational education degree. Such difficulties were also encountered by many other respondents in Strasbourg. This suggests that one significant difference between early stable and stable transitions is that young people in stable transitions have often had negative labour market experiences that encourage them to remain in their current jobs. Deniz's desire for stability 
was not only related to her marital status but also to her precarious position at work and the harsh labour market conditions in Strasbourg.

One other point I would like to underline is the potential influence of workplace experiences. Both Deniz and Tülin had had unpleasant experiences and had been forced to justify their religion or physical appearance. Tülin had to deal with the impact of her decision to wear a headscarf on her relationship with her colleagues, and this made her reluctant to try her chances elsewhere. Despite the fact that her workplace was in west Amsterdam and served a majority-minority clientele accustomed to Islamic dress codes, she doubted that she would have been hired if she had worn a headscarf to her job interview. This made Tülin wary about the job opportunities that would be available to her should she wish to leave her current position. In a similar vein, Deniz's experience of being hidden away in the solicitor's office taught her about the problem of prejudice in the labour market and put her off looking for a job at a different solicitor's firm, even though her hopes of promotion at her present workplace had been quashed.

\subsubsection{Shifting Rather Than In-transition or Stagnant Transitions: "It's Easy to Find a Job; It's Hard to Find a Good Job"}

Respondents in shifting transitions experienced frequent job shifts and unemployment, and therefore had not been able to find a steady job. In this section we will compare three profiles in different settings: two active and one unemployed. However, even though the unemployed respondents were not working at the time of our encounter, they had previously shifted between jobs and statuses.

\section{Shifting Transition: Cengiz, 28, Plumber, Strasbourg}

Cengiz's father migrated to Strasbourg as a guest worker and was later joined by his family. He had not completed primary education and worked in construction. Cengiz's mother had no education at all and she was occupied with household duties. The couple had five children. Both Cengiz and his younger brother were born and raised in France. His older sisters stopped studying because of the headscarf ban in France. Cengiz had been married for 6 years and had two daughters. His wife was from his parents' village and migrated to Strasbourg when they got married. They were living in a social housing block in one of Strasbourg's majorityminority neighbourhoods.

Cengiz was good at school, particularly at mathematics. Despite his high grades, his father advised him to take up plumbing to gain a trade after observing that plumbers in the construction business were never out of work. Cengiz wanted to become a mechanic, but his mother opposed his decision, saying she didn't want 
him to come home with oily clothes. Following his family's wishes, he studied plumbing at vocational college. Cengiz's choice was thus both gendered and familydriven. Vocational training was not challenging for Cengiz, and he achieved very high grades without effort (he actually found the course less challenging than secondary education). During this period, his family opened their own supermarket and Cengiz started working in the family business in his spare time.

At the end of Cengiz's vocational training, his grades were so exceptional that his teachers advised him to go to lyceum. He enrolled at professional lyceum but found it difficult to combine his now more demanding studies with working in the family business and playing football in the semi-professional league. In the end, he decided to drop out of school for good, as he had a trade to fall back on. However, his vocational training in plumbing had included only short and infrequent internships through a customer of his family's supermarket, and most of his work experience had been gained in the supermarket.

Upon leaving school, Cengiz did not seek work in his chosen profession, but signed up with employment agencies and did whatever unskilled job came along. For the first 2 years, he worked on an assembly line in an automobile factory via an employment agency contract that was renewed every few months. During that period, he got married and he and his wife continued to work in the family business alongside his job in the factory. He enjoyed working with machinery in the automobile factory, but when he left work for a month so that the family could visit Turkey, his position was no longer available upon his return. He then found work as a deliveryman for a courier company, and enjoyed the driving and mobility. However, he quit this job after receiving so many traffic tickets that he was in danger of losing his driving license. He returned to the employment agency, finally getting a job in a large plumbing company of 150 employees that served the construction industry in Strasbourg. At the time of our interview, he still did not have a permanent contract, despite having worked there for three and a half years. He was still on short-term contracts provided through the employment agency.

Since leaving education, Cengiz had been registered with an employment agency (interim) that outsourced unskilled or low skilled jobs. In 8 years of employment, he had not once been offered a permanent contract. His contracts were automatically renewed every one or 2 months because a six-month contract would oblige his employer to offer him a permanent contract (embouché) when it expired. Cengiz didn't express any resentment about having a temporary contract, as a permanent contract wouldn't mean a drastic change in his income, which was $€ 1400$ a month, just above the minimum wage (SMIC). His current job required him to work under very difficult conditions and was physically demanding. Nevertheless, he planned on pursuing it as he did not want to risk becoming unemployed during an economic crisis, even though he had never had any difficulty finding a job up until that point. He said that he might consider starting his own company, but was in no hurry. The family business seemed also a burden to him, as he and his wife had to work weekends and holidays in the supermarket.

Cengiz had thus shifted between various, mostly low-skilled, jobs and had not yet found stability in one job or career. He also had no clear plan about what to do 
next. One striking factor in the precarious nature of Cengiz's jobs was the role played by employment agencies. The constructions offered by these agencies allow employers to transfer almost all of their employer's risks to their employees, who could be fired every other month. Furthermore, Cengiz felt entirely responsible for taking care of his family, as his wife was not employed, and tried to avoid unemployment by accepting any job that came along.

\section{Stagnant/In-transition/Shifting Transition: Emre, 25, Unemployed, Amsterdam}

Emre's father had arrived in the Netherlands at the age of 15, along with his father who had been hired as a guest worker. He spoke Dutch and had worked as a driver for 20 years but had been on sick leave for 5 years at the time of the interview. Emre's mother came to the Netherlands to marry his father. She had obtained a vocational degree in Turkey and worked as a Turkish language instructor in primary and secondary schools in Amsterdam for many years. She became unemployed after Turkish language teaching was dropped from the state curriculum. Emre's mother was the most highly-educated mother in the qualitative sample. Emre's older sister had recently graduated from tertiary vocational training.

Emre grew up in the east of Amsterdam and attended school there. After scoring poorly in the CITO test at the end of primary school, he was advised to follow the vocational track. He had good grades in mathematics but had problems with Dutch language proficiency. He claimed that neither he nor his parents were informed about the implications of the CITO tests in primary school and was highly critical of the early stratification in the Dutch education system.

In senior vocational training (MBO), Emre first enrolled in information and communications technology. However, 1 year later he switched to sales and commerce (handel). Like most of his peers in the Netherlands, Emre found a part-time job when he was 17 . He switched between cleaning planes, working in the airport baggage section, and stacking shelves in supermarkets. While these jobs provided him with an income, they also affected his studies, though he successfully graduated from vocational college at the age of 21 . He then registered at a tertiary vocational college (HBO) to study social work (maatschappelijk werk). Six months later he decided this was not the profession for him and dropped out. In the meantime, he continued with his part-time jobs and arranged his working hours around his studies, switching between full-time and part-time employment.

After he dropped out of tertiary education, he looked for another job related to his sales and commerce course. He applied to a few stores and got a job at H\&M in one of the busiest shopping streets in Amsterdam. However, the store was too hectic and the work too hard, so he quit after 4 months. He said that he could have become a store manager if he had stayed, but he didn't like the job. He decided to return to education. This time he attended a tertiary course at an HBO in business administration and economics, which he thought would be a suitable follow-up to his vocational major. However, this programme was much more challenging than he 
expected, and once more he quit before the end of his first semester. In the meantime, he was registered in the employment centre, continued to live with his parents and do all sorts of service jobs to secure an income.

At the time of our interview, Emre was unemployed after returning from his holidays in Turkey. He had just applied for unemployment benefit as he couldn't find a job he liked. He had given up his last job, in a supermarket, after a couple of months to go on holiday. He was actively seeking work and hoping to hear from a friend who had promised to find him a job as a sales assistant in a mobile phone store.

EMRE: Having an MBO diploma didn't really give me an advantage. But maybe if I had tried harder it [having an MBO diploma] could have [helped]. For example, I worked in a clothing store. But I didn't like it. It was so busy and you constantly have to tidy and fold stuff. Maybe if I had persisted I could become a floor manager or something. But I didn't. It was so tiring. Now I am thinking of working in a phone store. I am not sure. Or maybe I will go back to school. I am thinking of starting in February.

INTERVIEWER: Did you decide on what to study?

EMRE: I am thinking of the HVA (Hogeschool van Amsterdam) I have studied there before. I also want to study, but, you know, it depends. I also want this phone business to come through.

Emre was quite disappointed about how his transition had turned out. He complained that it was impossible to find a decent job, despite sending many applications, saying, "It's easy to find a job; it's hard to find a good job". Furthermore he emphasized how hard it had been to find low-skilled jobs since the start of the economic crisis.

Emre had been unemployed for 3-4 months and could therefore be consigned to the in-transition latent class. However, as he had still no job stability despite having left school over 4 years ago, he could also be said to be in a stagnant transition. Not only had he not achieved any stability in his career, but he had constantly drifted between periods of employment, training and unemployment with no clear direction and gave an impression of dissatisfaction and hopelessness. Although he had a vocational degree, this didn't seem to provide any stability, as he did not know how to use it to find a job that he would enjoy doing. His attempts to enter vocational tertiary education also lacked focus. His situation seemed to be due to a combination of motivational and structural disparities. If we had interviewed him when he was working, however, he would have qualified as a shifter as he would have been shifting between statuses.

Emre's case is an interesting example in the Dutch context, as his vocational training did not lead to a significant development of cultural or social capital related to his studies. During his commerce course, he conducted an internship in the supermarket where he worked part-time. Therefore his networks and resources were derived from his student jobs. Neither Emre's vocational training nor his attempts at higher education were a match with his ambitions on the employment market. Lehmann argues that occupation-specific vocational training lacks the flexibility that comprehensive systems provide: if you do not want to do work related to your 
qualifications or if you do not possess the resources and the cultural capital required for your occupation, you risk falling between the cracks (Lehmann 2007). Occupation-specific training provides an environment where many young people can extend their networks, learn more about their trade and discover what their future occupation will entail. Although Emre lacked this form of social and informational capital, he gained other resources through his work contacts that he hoped would help him to find work.

Previous studies have defined stagnant transitions as those in which young people drift between employment and unemployment with no increase in stability (Plug and Bois-Reymond 2006). Bradley and Devadason's (2008) shifters drifted between jobs, unemployment and training, either by choice or due to structural conditions. According to the latent class analysis, those with stagnant transitions had a high estimated likelihood of having been unemployed for longer than 12 months. In Amsterdam, none of the inactive interviewees had been unemployed for longer than 12 months. However, in Strasbourg, some female respondents who had never worked despite wanting to enter the labour market fitted these profiles. As the qualitative data provided more detailed information about past employment experience and motivations, it is possible to reorganize typologies rather than trying to strictly match the latent classes. In both settings, those who were unemployed usually switched between different jobs and statuses, similar to Cengiz and Emre. While Emre's case suggests a lack of direction, others didn't have the luxury of choosing a job or career pathway: instead they focussed on staying employed and acquiring a contract, if possible. As a result, those classed as stagnant or in-transition should be subsumed under the shifting category as they have not yet made a stable transition. This is also more optimistic than terming their transitions stagnant, as potentially they are open to change.

\subsubsection{Inactive Transition Trajectories}

According to our latent class analysis, there was a high estimated probability that respondents whose transitions had led to inactivity would be uninterested in entering the labour market. In Amsterdam, $60 \%$ of this category consisted of homemakers compared to $22 \%$ in Strasbourg. Even though many respondents were not active during the qualitative interviews, it is hard to place them in this category since they were motivated to work and some of them wanted to study. In order to grasp the motivations behind "not wanting to enter labour market", this section will present the following trajectory, that of Kader. 


\section{Inactive: Kader, 26, Homemaker, Strasbourg}

Kader had had a difficult home life. Her father had arrived in France as a guest worker in the 1970s, and was soon joined by Kader's mother and disabled older brother. Tragically, Kader's mother died while giving birth to her. Left with two small children to bring up, her father married a woman from his village in Turkey. Kader grew up with her stepmother and four younger step-sisters in a difficult family environment. School was a refuge from home and she was a good pupil. She put all her energy into her studies and did quite well in mathematics and French. Her education career looked bright until a confrontation over her Islamic practices with a secondary school teacher, who bullied her for wearing a headscarf and fasting during Ramadan. Her grades started to fall and eventually she lost interest in studying. At the end of collège, Kader was advised to attend the vocational track, and she agreed as she didn't see much point in the academic track or university. She was happy to learn a trade and start working, so she chose textiles and sewing. However, this led only to dead-end jobs. Furthermore, work in the textile industry was located in the outlying regions of Alsace, and her father would not allow her to commute to work. Acting on her teachers' advice, she went on to professional lyceum in commerce and sales, but dropped out before obtaining her baccalauréat diploma. By then she was 18 and as the eldest girl in the household, she was expected to get married. Kader was allowed to "choose" between two cousins: one from her father's side and the other from her step-mother's side. She chose to marry the latter in the hope of avoiding the birth defect caused by inbreeding that had resulted in her brother's disability (her biological parents were also cousins).

Once the couple were married, they had to work hard to survive. Kader got a job in a store but it didn't last long as she was too shy to talk to the customers. She then did cleaning jobs along with her husband, and together they would clean schools, businesses, factories and stores. She continued working until she fell pregnant with her first child. She took a break from work but went back after the birth of her second child. Kader and her husband worked shifts and as their family did not help them with childcare, the children were left alone in the house for $1 \mathrm{~h}$ every day as her husband had to leave for work before Kader got home. They bought a phone with a screen so that she could talk constantly to the kids until she got home.

At the time of the interview, Kader had four children; the third pregnancy had turned out to be twins. The family were living in a two-bedroom apartment in a neighbourhood infamous for its high poverty and crime rates. Kader stayed at home to take care of the children and had no interest in working as her only options were cleaning or other unskilled jobs. She didn't have social networks that could connect her to better jobs. She and her husband had little contact with their families and preferred to keep it that way. Her husband was working on an assembly line on the outskirts of Strasbourg and had to cycle to work for 40 min every morning. Kader's greatest ambition was for him to find a stable job. 
Kader's case is extreme, but her story raises fundamental questions about the opportunities that education systems or labour market conditions provide for young people who have no support mechanisms at home. Kader sought refuge in school, but couldn't find it there. Despite her vocational degree, the only work available to her was poorly paid and unpleasant. For Kader, work meant drudgery, an obligation she would rather avoid.

Compared to Deniz, who had strong emotional support and financial capital at home, and Tülin, whose vocational educational trajectory built the cultural and informational capital she needed to enter the labour market, Kader found neither parental nor institutional support. Furthermore, as in the cases of Emre, Cengiz and Kader, Kader's family lacked the cultural capital needed to help her find a suitable study programme or occupation.

\subsection{Conclusion: Stable versus Shifting Transitions Among Descendants of Migrants from Turkey}

Almost all of the respondents in this study were motivated to seek stability in the labour market and wanted to pursue institutionally defined "traditional pathways", prompted by both labour market conditions and job insecurity. Personal experiences of instability motivated them to stick at a job once they had secured a permanent position. Lack of security dragged other respondents into shifting transitions, not out of choice but born of necessity. In this way, their aspirations are similar to the "stickers" in Bradley and Devadason's (2008) study and the "smooth transitions" in the YOYO study (Plug and du-Bois Reymond 2003), who wanted to keep their job and settle in a career.

Although the respondents in both Strasbourg and Amsterdam had similar "stability" motivations, the nature of "stability" and transitions differed: the TIES survey analysis showed that the respondents in Amsterdam acquired stability at an earlier age than their peers in Strasbourg, who had longer periods of job searching and shifting before acquiring stability. Despite being in the labour market for considerable lengths of time (a minimum of over 3 years and up to 10 years in the interview profiles), shifters in Strasbourg still did not have a permanent contract. Qualitative interviews revealed that internship and student employment practices were instrumental to achieving early stability since respondents tended to stay with the same employer. Parental resources and the different forms and degrees of capital accrued during individual trajectories also proved instrumental during youth transitions. Following young people after they left school, we saw that those who were able to accumulate cultural and social capital through family, community or work experience contacts were also more able to acquire stable working arrangements. 
With regard to the lack of stability, while the latent class analysis distinguished stagnant and in-transition typologies, the qualitative interviews suggested that both categories could be subsumed under the shifting type, as the conditions of shifting between employment, unemployment and training, were similar for all the young people in these groups. This finding diverges from previous typologies of transitions, which also perceived shifting transitions as being "out of choice", prompted by a desire to pursue alternative pathways (cf. Plug and du-Bois Reymond 2003; Bradley and Devadason 2008). In the case of my respondents, shifting was the result of precarious labour market conditions in which employment agencies provided jobs but no security whatsoever. Failure in the labour market nudged some respondents back into education, but as most of them had no clear direction this also failed to lead to a stable outcome for them. Even though Amsterdam provided more opportunities for stable transitions at an earlier age, transitions could be precarious and become shifting if one lacked the necessary education or cultural capital. An example of this is Emre from Amsterdam, whose lack of symbolic or cultural capital and a clear idea of what kind of work he wanted to do resulted in unstable conditions despite the institutional opportunities.

Another interesting finding was that marriage patterns and family life often helped to sustain some sort of stability in the lives of inactive respondents, as Evans and Heinz (1994) have shown in their study on women from a workingclass background in the UK. These profiles also showed that the choice to stay at home resulted from a lack of training opportunities and/or unpleasant working conditions. Rather than shifting between statuses, some young women preferred to stay at home and take care of their children in order to acquire a sense of stability and adulthood status.

Among the respondents who sought stable transitions, I identified certain experiences specific to the descendants of immigrants. These were experiences of exclusion and discrimination in the workplace that have also been documented in previous studies (Waldring et al. 2015). Religion also played a role, and it was particularly difficult for young women wearing a headscarf to be accepted. Past experiences of discrimination or a lack of acceptance in the workplace informed these young people's perceptions of conditions in the labour market. Hence, once they had secured a position they were inclined to stick at their jobs, rather than risking a new job or pursuing "alternative careers". These findings can also easily apply to youth from lower social classes who also possess limited resources and have to deal with an insecure job market. While the concepts of alternative or shifting careers are interesting, researchers in the field of youth transitions should scrutinize them further in relation to social class, ethnicity and gender differences to see whether they apply to all young people and if so, under which conditions (Tables 5.7, 5.8 and 5.9). 


\section{Appendix}

Table 5.7 Latent class measurement models fitted to data on transition trajectories

\begin{tabular}{|c|c|c|c|c|c|c|c|c|}
\hline Model & $\begin{array}{l}\# \\
\text { Classes }\end{array}$ & AIC & $\mathrm{BIC}$ & $\mathrm{x} 2$ & $\mathrm{P}$ & Entropy & $\begin{array}{l}\text { Tech 11- } \mathrm{P} \\
\text { value for } \mathrm{n}-1\end{array}$ & $\begin{array}{l}\text { Class } \\
\text { distributions }\end{array}$ \\
\hline \multicolumn{9}{|c|}{ Amsterdam active } \\
\hline Model1 & 1 & 3664.72 & 3710.86 & 2707.62 & 0.01 & NA & NA & NA \\
\hline Model2 & 2 & 3511.34 & 3607.16 & 1873.2 & 1 & 0.89 & 0 & $26 \%, 74 \%$ \\
\hline Model3 & 3 & 3466.02 & 3611.541 & 1613.19 & 1 & 0.845 & 0.0014 & $\begin{array}{l}16.7 \%, 55.3 \%, \\
28 \%\end{array}$ \\
\hline Model4 & 4 & 3426.64 & 3621.84 & 1315.97 & 1 & 0.87 & 0.0021 & $\begin{array}{l}15 \%, 15 \%, \\
51 \%, 19 \%\end{array}$ \\
\hline \multicolumn{9}{|c|}{ Strasbourg active } \\
\hline Model1 & 1 & 3014.58 & 3057.97 & 3088.43 & 0 & NA & NA & \\
\hline Model2 & 2 & 2895.26 & 2985.37 & 2194.11 & 1 & 0.83 & 0.0015 & $60 \%, 40 \%$ \\
\hline Model3 & 3 & 2833.06 & 2969.89 & 1662.28 & 1 & 0.86 & 0.0017 & $\begin{array}{l}36 \%, 27 \%, \\
37 \%\end{array}$ \\
\hline Model4 & 4 & 2801.83 & 2985.39 & 1456.21 & 1 & 0.847 & 0.1541 & $\begin{array}{l}29 \%, 18 \%, \\
29 \%, 24 \%\end{array}$ \\
\hline \multicolumn{9}{|c|}{ Amsterdam inactive } \\
\hline Model1 & 1 & 544.135 & 558.04 & 117.79 & 0 & NA & NA & \\
\hline Model2 & 2 & 506.394 & 536.521 & 36.153 & 0 & 1 & 0 & $40 \%, 60 \%$ \\
\hline Model3 & 3 & 511.34 & 557.69 & 27.035 & 0.97 & 0.86 & 0.0276 & $\begin{array}{l}40 \%, 44 \%, \\
16 \%\end{array}$ \\
\hline Model4 & 4 & 517.581 & 580.153 & 13.091 & 0.99 & 0.89 & 0.15 & $\begin{array}{l}5 \%, 17 \%, 35 \% \text {, } \\
43 \%\end{array}$ \\
\hline \multicolumn{9}{|c|}{ Strasbourg inactive } \\
\hline Model1 & 1 & 613.362 & 627.947 & 201.906 & 0 & NA & NA & \\
\hline Model2 & 2 & 590.809 & 622.41 & 103.007 & 0 & 1 & 0.0009 & $40 \%, 60 \%$ \\
\hline Model3 & 3 & 577.25 & 625.866 & 43.746 & 0.43 & 0.825 & 0.01 & $\begin{array}{l}37 \%, 30 \%, \\
33 \%\end{array}$ \\
\hline Model4 & 4 & 585.092 & 650.724 & 32.356 & 0.64 & 0.849 & 0.3083 & $\begin{array}{l}37 \%, 30 \%, 6 \% \text {, } \\
27 \%\end{array}$ \\
\hline
\end{tabular}

Source: TIES Survey 2008 
Table 5.8 Transition Trajectories by education level in Amsterdam and Strasbourg

\begin{tabular}{|c|c|c|c|c|}
\hline \multicolumn{5}{|l|}{ Amsterdam } \\
\hline & $\begin{array}{l}\text { Lower Sec.Voc. } \\
\text { (VMBO) }\end{array}$ & $\begin{array}{l}\text { Post-secondary } \\
\text { (HAVO/VWO/MBO) }\end{array}$ & \multicolumn{2}{|c|}{ Tertiary Edu (HBO/Uni.) } \\
\hline Early careers & $22 \%$ & $30 \%$ & \multicolumn{2}{|l|}{$42 \%$} \\
\hline $\begin{array}{l}\text { Stable } \\
\text { careers }\end{array}$ & $24 \%$ & $36 \%$ & \multicolumn{2}{|l|}{$42 \%$} \\
\hline Shifters & $11 \%$ & $10 \%$ & \multicolumn{2}{|l|}{$4 \%$} \\
\hline Inactive & $21 \%$ & $13 \%$ & \multicolumn{2}{|l|}{$1 \%$} \\
\hline Stagnant & $18 \%$ & $9 \%$ & \multicolumn{2}{|l|}{$7 \%$} \\
\hline In-transition & $4 \%$ & $3 \%$ & \multicolumn{2}{|l|}{0.04} \\
\hline $\mathrm{N}$ & 72 & 111 & \multicolumn{2}{|l|}{149} \\
\hline \multicolumn{5}{|l|}{ Strasbourg } \\
\hline & $\begin{array}{l}\text { LowerSec. } \\
\text { (College) }\end{array}$ & $\begin{array}{l}\text { Vocational Post. Sec. } \\
\text { (CAP/BEP) }\end{array}$ & $\begin{array}{l}\text { Academic Post } \\
\text { Sec.(BAC) }\end{array}$ & \begin{tabular}{|l} 
Tertiary Edu \\
(BTS/Uni/CPGE)
\end{tabular} \\
\hline Early careers & $11 \%$ & $16 \%$ & $38 \%$ & $36 \%$ \\
\hline $\begin{array}{l}\text { Stable } \\
\text { careers }\end{array}$ & $20 \%$ & $19 \%$ & $22 \%$ & $15 \%$ \\
\hline Shifters & $28 \%$ & $35 \%$ & $31 \%$ & $32 \%$ \\
\hline Inactive & $10 \%$ & $13 \%$ & $6 \%$ & $8 \%$ \\
\hline Stagnant & $17 \%$ & $5 \%$ & 0 & $1 \%$ \\
\hline In-transition & $14 \%$ & $13 \%$ & $3 \%$ & $7 \%$ \\
\hline $\mathrm{N}$ & 123 & 63 & 32 & 74 \\
\hline
\end{tabular}

Source: TIES Survey 2008

Table 5.9 Transition trajectories by age group in Amsterdam and Strasbourg

\begin{tabular}{l|l|l|l|l|l|l}
\hline & \multicolumn{2}{|l|}{ Age group 18-22 } & \multicolumn{2}{l|}{ Age group 23-29 } & \multicolumn{2}{l}{ Age group 30+ } \\
\cline { 2 - 7 } & Amsterdam & Strasbourg & Amsterdam & Strasbourg & Amsterdam & Strasbourg \\
\hline Early stable & $27.3 \%$ & $30.4 \%$ & $21.1 \%$ & $27.7 \%$ & $20.5 \%$ & $1.0 \%$ \\
\hline Stable & $20.5 \%$ & 0.0 & $40.9 \%$ & $19.7 \%$ & $53.8 \%$ & $48.5 \%$ \\
\hline Shifting & $11.4 \%$ & $16.1 \%$ & $11.1 \%$ & $26.3 \%$ & $16.2 \%$ & $32.3 \%$ \\
\hline Inactive & $9.1 \%$ & $23.2 \%$ & $13.5 \%$ & $6.6 \%$ & $2.6 \%$ & $6.1 \%$ \\
\hline Stagnant & $20.5 \%$ & 0.0 & $9.9 \%$ & $10.9 \%$ & $6.0 \%$ & $10.1 \%$ \\
\hline In-transition & $11.4 \%$ & $30.4 \%$ & $3.5 \%$ & $8.8 \%$ & $0.9 \%$ & $2.0 \%$ \\
\hline & 44 & 56 & 171 & 137 & 117 & 99 \\
\hline
\end{tabular}

Source: TIES Survey 2008

\section{References}

Bradley, H., \& Devadason, R. (2008). Fractured transitions: Young adults' pathways into contemporary labour markets. Sociology, 42(1), 119-136.

Du Bois-Reymond, M. (1998). "I Don't want to commit myself yet": Young people's life concepts. Journal of Youth Studies, 1(1), 63-79.

Evans, K., \& Heinz, W. (1994). Becoming adults in England and Germany. London: AngloGerman Foundation. 
Fenton, S., \& Dermott, E. (2006). Fragmented careers? Winners and losers in young adult labour markets. Work, Employment and Society, 20(2), 205-221.

Ganzeboom, H., \& Treiman, D. (1996). Internationally comparable measures of occupational status for the 1988 international standard classification of occupations. Social Science Research, 25, 201-239.

Gaskell, J. (1992). Gender matters from school to work. Toronto: Oise Press.

Granovetter, M. (2005). The impact of social structure on economic outcomes. The Journal of Economic Perspectives, 19(1), 33-50.

Hagenaars, J., \& Mccutcheon, A. (Eds.). (2002). Applied latent class analysis models. New York: Cambridge University Press.

Lehmann, W. (2007). Choosing to labour? School-to-work transitions and social class. Ithaca: Mcgill-Queen's University Press.

Lessard-Phillips, L., Fibbi, R., \& Wanner, P. (2012). Assesing the labour market position and its determinants for the second generation. In M. Crul, J. Schneider, \& F. Leslie (Eds.), The European second generation compared: Does the integration context matter? (Imiscoe Research Series) (pp. 165-224). Amsterdam: Amsterdam University Press.

Mccutcheon, A. L. (1987). Latent class analysis. London: Sage.

Plug, W., Zeijl, E., \& Du Bois-Reymond, M. (2003). Young people's perceptions on youth and adulthood. A longitudinal study from the Netherlands. Journal of youth studies, 6(2), 127-144.

Plug, W., \& Du Bois-Reymond, M. (2006). Transition patterns between structure and agency. In A. Walther, M. D. Bois- Reymond, \& A. Biggart (Eds.), Participation in transition motivation of young adults in Europe for learning and working. Frankfurt Am Main: Peter Lang.

Reay, D. (2004). Gendering Bourdieu's concepts of capitals? Emotional capital, women and social class. The Sociological Review, 52(s2), 57-74.

Santelli, E. (2012). Young adults of Maghrebi origin from the French banlieues: Social mobility in action? Journal of International Migration and Integration, 13(4), 541-563.

Waldring, I., Crul, M., \& Ghorashi, H. (2015). Discrimination of second-generation professionals in leadership positions. Social Inclusion, 3(4), 38-49.

Walther, A., Bois-Reymond, M. D., \& Biggart, A. (2006). Participation in transition motivation of young adults in Europe for learning and working. Frankfurt Am Main: Peter Lang Gmbh.

Yang, C. C. (2006). Evaluating latent class analysis models in qualitative phenotype identification. Computational Statistics \& Data Analysis, 50(4), 1090-1104.

Open Access This chapter is licensed under the terms of the Creative Commons Attribution 4.0 International License (http://creativecommons.org/licenses/by/4.0/), which permits use, sharing, adaptation, distribution and reproduction in any medium or format, as long as you give appropriate credit to the original author(s) and the source, provide a link to the Creative Commons licence and indicate if changes were made.

The images or other third party material in this chapter are included in the chapter's Creative Commons licence, unless indicated otherwise in a credit line to the material. If material is not included in the chapter's Creative Commons licence and your intended use is not permitted by statutory regulation or exceeds the permitted use, you will need to obtain permission directly from the copyright holder.

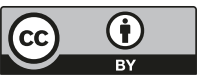




\section{Chapter 6 \\ Conclusion: Developing Forms of Capital in Youth Transitions}

Increased demand for academic credentials and the growing risk and insecurity in the employment market over the past few decades have had a profound effect on young people. The majority of scholars in the field share the observation that these neoliberal trends lead to prolonged and more complex youth transitions (Bradley and Devadason 2008; du Bois-Reymond 2009; Furlong 2009; Heinz 2009). Yet, their opinions diverge regarding the implications of the changing nature of transitions. One camp argues that these conditions lead to more individualized transitions, lessening the impact of structures and compelling young people to "navigate" their own pathways and assert agency (Beck 1992, 2007; Giddens 1991). In the other camp are scholars, such as Côté (2014a, b), who argue that youth have become even more vulnerable and forced to depend more heavily on social and institutional structures. Many other researchers position themselves somewhere between these camps, pointing to both the persisting roles of structures and increasing individual creativity in navigating transitions (Evans and Furlong 1996; du Bois-Reymond 2009; Furlong 2009). Barely accounted for in this discussion, however, is the experiences of immigrants' descendants. This is a blatant omission, considering that ethnic minority youth, as they are often called, comprise one of the largest groups in today's diverse cities and are statistically recognized as among the most vulnerable. While ethnic and migration studies and social stratification research focus on how this group integrate within the education system and labour market, neither research paradigm has yet explored how immigrants' descendants experience the process of youth transition. As this book has demonstrated, transition experiences presage the future of these groups in society and, considering how large the group is, this will have broader social implications. This study was inspired by seminal debates in youth sociology concerning new forms of transitions. It is my aim to contribute to this debate by exploring the case of native-born descendants of Turkish immigrants-now one of the largest ethnic minority youth groups - in Western European cities. The findings of the study, which analyzes the role of social structures-social class, gender and 
ethnicity-in shaping youth transition processes across different institutional settings in Amsterdam and Strasbourg, has relevance for both camps of scholarship.

My detailed look at this group's social trajectories from a young age revealed that not all native-born descendants of Turkish immigrants experience prolonged and complex transitions. Their ability to successfully prolong their transitions and combine various activities depends on institutional structures, the forms of capital available to them through their families and the resources they develop over time in their social trajectories. This finding highlights the role of social class, placing it firmly at an intersection with ethnicity and gender. It also brings the varying conditions of different localities into sharp relief. Prolonged youth transitions are therefore not something that can be taken for granted.

This book also offers some crucial theoretical contributions to youth studies and ethnic and migration studies by studying social class through the lens of different forms of capital. The analysis of the role of social class, through observing the forms of capital that are utilized in youth transitions is innovative and, more importantly, constructive in different ways. Following on from Savage et al. (2005) this study has looked at the forms of capital that migrant parents can provide, which has yielded a more nuanced analysis of social class at the micro-level, uncovering those parental resources that can really make a difference to their children's transitions. My qualitative interviews revealed that some respondents' parents had developed relevant cultural capital, such as practical information about how the education system in the host countries works. Also significantly impacting the young people's trajectories was their parents' ability to provide them with financial support and social capital, which might, for example, be generated by running their own business and developing networks and contacts along the way. Clearly these forms of capital are not identical to that of the middle-class within the comparison group, yet they bred distinction among migrant parents. The variance of such parental resources-based on their generation, origin and/or employment experience-shows that significant intra-group differences are to be found within ethnic minorities (Erel 2010).

That said, tapping resources requires determining whether the forms of capital are valid resources within the institutional settings in the first place. This is in line with Bourdieu's theory which states that forms of capital only make sense in fields wherein value is bestowed on the related resources. As shown in Chap. 1 of this book, parental cultural capital and students' aspirations had more influence on tracking decisions in Strasbourg than in Amsterdam, where they were more often strictly dependent on grades and teacher recommendations. This finding shows that similar resources may not yield the same advantages in different institutional settings. Members of the "same ethnic group", even if they possess similar resources, can thus have distinct experiences unique to the institutional structures in which they find themselves.

The study also identified forms of capital that were specific to the group in relation to social class, gender and ethnicity pointing to that fact that researchers should remain open to the different forms of capital that are generated according to social class and gender within the ethnic community and not limit themselves to studying 
dominant middle-class forms of capital, as Bourdieu initially proposed. This echoes the critics of Bourdieu, including some feminist scholars (Skeggs 2004a, b; Reay 2004) and researchers of social mobility (Friedman 2016), who argue that forms of capital are a useful analytic tool, but that the study of non-middle-class groups requires a much more flexible understanding of different forms of capital. For example; the existence of a construction sector niche among the Turkish community in Strasbourg supplied social capital and employment for the young males in the community. This social capital was also utilized by female respondents who married firstgeneration Turks ("import grooms") needing jobs that required no French-language proficiency. This example is not one of "ethnic capital" per se (Zhou 2005), though it did emerge from networks within the ethnic group. In Amsterdam, this resource was not available to the same extent, due to the city's economic structure and the lack of existing niches in any sector. In addition, the altruism of migrant mothers to provide emotional and physical resources can only be understood in relation to gendered norms in the community, in which women are expected to care for the household. To enable the younger generation of women to work and study, non-working mothers and mothers-in-law often took over these tasks. This finding illustrates the importance of familial assistance in coping with increasing individualization, risk and insecurity during youth transitions (Jones 2009). The kind of assistance apparent in my study was very much informed by the intersections of gender, social class and ethnicity, as opposed to more middle-class specific resources.

\subsection{Developing Forms of Capital Throughout the Transition Process}

Perhaps the most novel contribution made by this book lies in its examination of how immigrants' descendants develop forms of capital in their social trajectories, and how these resources influence their transitions. Previous studies have highlighted the forms of capital available to migrants and have noted how they vary within groups according to their social class, gender and the resources imported from origin countries (Erel 2010; Ryan et al. 2015). I developed this line of thinking, choosing not to limit the study to social capital or forms of capital provided by migrant parents. Treating transitions as a process that begins early in education and continues later into the labour market and/or other events, such as matrimony, I studied how descendants of Turkish immigrants themselves managed (or not) to develop forms of capital to help them through their transitions. This approach, first and foremost, treats descendants of Turkish immigrants as agents of their own transitions and that transition outcomes are not solely determined by parental background or structures. However, this generation of capital also needed contextualizing, both in the light of the institutional structures in which the respondents found themselves from early education onwards, and in terms of the resources they could access considering their social class, gender and ethnicity. This enabled me to show how the social and institutional structures in their social trajectories both enabled and constrained 
descendants of Turkish migrants in augmenting their resources. When proposing the concept of social trajectory, Bourdieu (1984) recognized the possibility for developing forms of capital, though he emphasized that the slope of development would be bound by a trajectory's starting point - in other words, that young people are likely to reproduce their parents' initial capital. While I observed many respondents reproduce initial disadvantages, I also uncovered others who were able to overcome this and achieve upward mobility. The assumption that the reproduction of disadvantaged status is inevitable impedes a clearheaded evaluation of the institutional structures that might also help young people to overcome their parents' initial disadvantage.

How did they overcome reproduction of disadvantage and achieve upward mobility? There the institutional opportunity structures play a crucial role. For example, access to internships and relevant part-time jobs can allow young people to hone their occupational skills and amass cultural and social capital that will ease their (future) transition into the labour market. This was particularly crucial for higher-education students who lacked access to social networks via their parents or wider family. Internship and job options were more accessible in Amsterdam than Strasbourg. Although the research did not initially intend to explore the benefits and drawbacks of combining work and school, I observed a remarkable difference between the two settings. Amsterdam's greater array of student jobs and more flexible schooling arrangements resulted in greater participation in work-study combinations and helped young people to develop financial and social capital. Most respondents in my sample came from low-income families, and being more financially independent meant that they were less reliant on their parents when it came to their transition decisions.

One of the significant findings of this study centred on the educational trajectories young people were following, or had followed and the possibility to explore whether these trajectories helped them to develop relevant forms of capital. Key findings here included whether their institutional structures provided applicable work and study combinations and the extent to which developing social and financial capital helped keep them in school. In this framework, Amsterdam provided more favourable conditions than Strasbourg: descendants of immigrants in the Dutch capital benefitted from better labour market opportunities, both during and after their school-to-work transition, and various other structures prepared them better for the tough labour market conditions awaiting them.

\subsection{The Intersections of Social Class, Gender and Ethnicity in Youth Transitions}

The intersections of social class, gender and ethnicity shaped the transition processes of my respondents in a variety of ways. This book shows how youth transitions involve differently gendered motivations and pathways. Traditional gender norms prevailed in the Turkish ethnic community, more so in Strasbourg than Amsterdam. Most male respondents felt pressured to have an income from a young age, especially if they did not feel that education offered them better prospects or if their families could not support them in continuing their education. Bynner (2001) 
found that young men from lower-class families in the UK faced similar conditions, completing minimum education and entering the labour market much earlier than their middle-class peers. Social class background and gender thus interact to limit these young men's options. In my study, the ethnic community's clearly gendered values intersected with financial resources and social class. Migrant parents with successful businesses can be more supportive of both their sons and daughters prolonging their studies. Yet, institutional structures also mattered. Amsterdam's flexible student jobs market enabled young men from low-income families to work while studying, making them less financially dependent on their families and more able to make autonomous decisions. Their counterparts in Strasbourg felt much more pressure when they sought to combine work with studying, which often led them to drop out of education and take a full-time job in the low-skilled labour market.

Previous studies have shown that marriage remains, by far, the most acceptable form of union formation within the Turkish ethnic community (Huschek 2011). My study shows that matrimony is also a valid transition pathway, especially for women with few educational or labour market prospects. Premarital cohabitation is not socially or culturally acceptable within the Turkish diaspora and most young women married partners from a similar background or from their parents' hometowns in Turkey, which enabled them to leave their parental home and transition to adulthood roles. In addition to their household tasks, many of these married young women also had to go out to work to supplement the income of their migrant husbands, most of whom had low-skilled jobs. As discussed in Chap. 4 of this book, the decision to marry early should be evaluated in the light of other transition experiences in education and the labour market. Rather than marriage being a stumbling block to further education or labour market progression, it was perceived as a way out-a door that could open up many other options. That said, other respondents who successfully prolonged their studies and found steady employment, postponed their decision to marry. Those who could rely on their families for forms of social or emotional capital were able to navigate complex transition pathways combining education, work and marriage. What does this finding imply for youth transitions field? The perception of matrimony as a gateway to adulthood or as the most conventional relationship status has undergone major transformations in Western Europe, and marriage is no longer taken as a sign of adulthood (Willoughby et al. 2015). Marriage is a ripe topic for future studies, which could examine this transition pathway's diminishing prominence in youth transitions. Scholars, including Wallace (1987) and Bynner (2001), have argued that for less-educated women, marriage and getting pregnant are valid transitions to adulthood, offering ways to gain respect and adulthood status. Yet youth transition studies have generally ignored the conditions affecting young people from lower-class or different cultural backgrounds, instead leaving much of the work on life-course research to demographers. Decisions about marriage and union formation should be included in studies of youth transition pathways: as this book has demonstrated, since they are crucial in shaping the motivations, decisions and opportunities of young people, particularly those from different ethnic and social class backgrounds.

Many of my respondents, both at school or in the labour market, were faced with the realities of discrimination and exclusionary practices. These negative experi- 
ences and fears of being excluded definitely shaped their transition motivations, as a result of which, the majority of my respondents sought stable, traditional transitions, rather than transitions that involved risk-taking or being adventurous in their educational or labour market ambitions. This observation is inextricably linked to the fact that these young people have had experiences that have made them understand the very real threat of ethnic penalties in the labour market.

\subsection{Comparative Research Design: Amsterdam and Strasbourg}

As the theoretical discussion of my findings has illustrated, the study's comparative approach highlighted the impact of institutional structures and city differences on young people's trajectories. Chapter 2 showed that while modern youth transitions are often described as "prolonged", extending education to delay transition can be less straightforward in some settings than in others. Early stratification within an educational system conditions how long transitions can be extended. Students on academic and vocational tracks have very different possibilities to pursue higher education, and this also depends on whether they are in Amsterdam or Strasbourg. In addition, there are differences between the academic tracks in the two countries: academic stream students in the Netherlands generally expressed a clear appreciation of the returns of higher education and made smooth transitions, while in France, there were more doubts as to whether higher education was worth pursuing. The comparative design, therefore, problematized the concept of 'prolonged transitions' not just influenced by social structure, but also by institutions. It confirmed and illustrated how institutional settings allow, and constrain, the possibility of a prolonged transition (Côté 2014a, b).

Previous studies have illustrated a distinction between institutionally designed traditional transitions and shifting or alternative biographies in which young people follow unconventional pathways (Plug and du Bois-Reymond 2006). Both in Amsterdam and Strasbourg majority of my respondents wanted to pursue stable ('traditional') transition pathways. Yet comparing two cities exposed how smooth transitions and traditional trajectories are uniquely shaped by settings. In Amsterdam, young people expected to, and experienced, stable careers at earlier ages, while their Strasbourg counterparts took longer to find stability in their careers. This was true for both the descendants of Turkish immigrants and the comparison groups. While majority of my respondents followed - or at least aspired to follow-stable, traditional pathways, for those who did not, their transition pathways did not always stem from their own orientations or preferences. Unlike previous studies; they were relatively unlikely to describe their shifting transitions as motivated by any desire to follow an alternative pathway. Most of their actions were not defined in the "moment of transition', but earlier on, during their educational tracking or while combining work and school, depending on whether they could develop forms of capital before entering the labour market. As such, my study calls for greater attention to how social and institutional structures set-if not altogether skew-the conditions of 
youth transitions. Both stable and alternative youth transitions should be scrutinized in relation to social class, gender and ethnicity.

While the bulk of transition studies emphasize the delay in transitioning to adulthood (Arnett and Tanner 2006), my research shows how the age of transition varies according to social and institutional structures. Social class, gender and ethnicity intersect to pressure the descendants of Turkish immigrants to achieve stability at an earlier age than their peers. Education and labour market conditions also affect the age at which these young people can achieve stability in their transition.

\subsection{Possible Future Avenues of Research and Policy Implications}

We need a change of perspective, in the domains of both research and policy, if we are to understand the youth transitions of descendants of migrants. The detailed study of parental resources reveals that future studies need to pay more attention to social class, especially on a micro-level, in order to understand how it affects young people's lives both in the field of ethnic and migration studies and in youth transitions research. While at first glance, many migrant parents seem to be capable of providing only limited resources due to their lower social class background, they can influence their children's trajectories by developing or possessing certain forms of capital. This could just as easily be true of working-class parents from a native background. Future ethnographies should focus on migrant parents and/or families and explore the impact of social class by examining the forms of capital generated at the nexus of social class, gender and ethnicity. In doing so, future studies should go beyond Bourdieu's theoretical framework and remain open to the possibility of uncovering forms of capital that may be specific to groups, localities and experiences.

Furthermore, studying the social trajectories of the second generation in detail revealed that young people are not bound by their parents' forms of capital and are able to develop resources which are crucial for their transitions. This theoretical contribution is key to understanding social reproduction and/or social mobility processes without either ignoring or over-emphasizing agency. It shifts the focus from the "agentic" aspect to the resources that agents are able to acquire within the given structural conditions. Their potential to develop forms of capital should therefore be studied comparatively, across institutional settings and with a sensitivity to variations in social structures. This approach would allow us to determine whether-and how well—countries of residence are fulfilling their obligation towards these groups to provide equal opportunities and whether certain support mechanisms - either financial or informational - are available. When discussing the attendance of young people from ethnic minorities or lower social classes at higher education institutions, we have to pay equal attention to funding mechanisms and access to student grants. We must question whether it is possible for young people to extend their transitions into tertiary education and what kinds of financial pressures they are faced with when doing so. This study made it very clear that financial concerns formed a major obstacle for young people who wanted to con- 
tinue their studies. In Strasbourg, they were faced with an inadequate student grants system, while in Amsterdam they afraid of having to repay their student loan, thereby incurring a huge debt, if they failed to graduate.

However, the comparative design showed how, despite their relatively disadvantaged backgrounds, members of the Turkish second generation are able to achieve successful transitions when provided with the right resources and guidance. Internships and work/study combinations emerged as significant experiences, which merit further scrutiny in both disciplines. It appears that having a student job is not just a factor that might jeopardize educational performance, but one that can also help students to develop resources for their future transitions. The implications for policy are that promoting internship programmes and dual training opportunities may not only help young people to gain early financial independence, easing the pressure on them to earn an income, but may also facilitate the development of social capital that is useful for their future transitions. In Strasbourg, the lack of sufficient dual training opportunities and the fierce competition to win a place on a dual study programme (BTS and Alternance) was revealed as a widespread concern for young people who had to combine work with studying due to financial constraints.

In Vassaf's (1983), study, the descendants of migrants from Turkey complained about "not getting their voices heard". Back then they were complaining about the lack of opportunities, resources and exclusionary practices. After almost 40 years of research on ethnic minorities, this study also highlights that societies and policy makers could still be doing more to respond to their needs and demands. This is an urgent necessity considering the future of the European diverse societies that are home to these ethnic minority youth.

\section{References}

Arnett, J. J., \& Tanner, J. L. (Eds.). (2006). Emerging adults in America: Coming of age in the 21st century. Washington, DC: American Psychological Association.

Beck, U. (1992). Risk society: Towards a new modernity. London/New York: Sage.

Beck, U. (2007). Beyond class and nation: Reframing social inequalities in a globalizing world. The British Journal of Sociology, 58, 679-705.

Bourdieu, P. (1984). Distinction: A social critique of the judgement of taste. Cambridge, MA: Harvard University Press.

Bradley, H., \& Devadason, R. (2008). Fractured transitions: Young adults' pathways into contemporary labour markets. Sociology, 42(1), 119-136.

Bynner, J. (2001). British youth transitions in comparative perspective. Journal of Youth Studies, 4, 5-23.

Côté, J. E. (2014a). Towards a new political economy of youth. Journal of Youth Studies, 17(4), 527-543.

Côté, J. E. (2014b). Youth studies: Fundamental issues and debates. Houndmills: Palgrave Macmillan.

Du Bois-Reymond, M. (2009). Models of navigation and life management. In A. Furlong (Ed.), Handbook of youth and young adulthood new perspectives and agendas (pp. 47-54). Oxon: Routledge.

Erel, U. (2010). Migrating cultural capital: Bourdieu in migration studies. Sociology, 44(4), 642-660. 
Evans, K., \& Furlong, A. (1996). Metaphors of youth transition: Niches, pathway, trajectories or navigations. In J. Bynner, L. Chisholm, \& A. Furlong (Eds.), Youth, citizenship and social change in a European context. Ashgate: Aldershot, Hants.

Friedman, S. (2016). Habitus clivé and the emotional imprint of social mobility. The Sociological Review, 64(1), 129-147.

Furlong, A. (2009). Handbook of youth and young adulthood. New perspectives and agendas. London: Routledge.

Giddens, A. (1991). Modernity and self-identity: Self and society in the late modern age. Stanford: Stanford University Press.

Heinz, W. R. (2009). Youth transitions in an age of uncertainity. In A. Furlong (Ed.), Handbook of youth and young adulthood new perspectives and agendas (pp. 19-29). Oxon: Routledge.

Huschek, D. (2011). Union formation \& partner choice of the second generation Turkish origin in Europe. Doctoral thesis, Vrije Univeristy.

Jones, G. (2009). From paradigm to paradox: Parental support and transitions to independence. In I. Schoon \& R. K. Silbereisen (Eds.), Transitions from school to work: Globalization, individualization, and patterns of diversity (pp. 145-164). New York: Cambridge University Press.

Plug, W., \& Du Bois-Reymond, M. (2006). Transition patterns between structure and agency. In A. Walther, M. D. Bois- Reymond, \& A. Biggart (Eds.), Participation in transition motivation of young adults in Europe for learning and working. Frankfurt Am Main: Peter Lang.

Reay, D. (2004). Gendering Bourdieu's concepts of capitals? Emotional capital, women and social class. The Sociological Review, 52(s2), 57-74.

Ryan, L., Erel, U., \& D’Angelo, A. (2015). Introduction understanding 'Migrant Capital'. In Migrant capital (pp. 3-17). London: Palgrave Macmillan.

Savage, M., Warde, A., \& Devine, F. (2005). Capitals, assets, and resources: Some critical issues. The British Journal of Sociology, 56(1), 31-47.

Skeggs, B. (2004a). Class, self culture. London: Routledge.

Skeggs, B. (2004b). Context and background: Pierre Bourdieu's analysis of class, gender and sexuality. The Sociological Review, 52(2_suppl), 19-33.

Vassaf, G. (1983). Daha Sesimizi Duyuramadık: Avrupa'daki Türk IşÇi Çocukları [We still Couldn't make our voices heard: The children of Turkish workers in Europe]. Istanbul: Belge Yayinlari.

Wallace, C. (1987). For richer, for poorer. London: Tavistock.

Willoughby, B. J., Hall, S. S., \& Luczak, H. P. (2015). Marital paradigms: A conceptual framework for marital attitudes, values, and beliefs. Journal of Family Issues, 36(2), 188-211.

Zhou, M. (2005). Ethnicity as social capital: Community-based institutions and embedded networks of social relations. In G. C. Loury, T. Modood, \& M. Steven (Eds.), Ethnicity, social mobility and public policy: Comparing the US and UK (pp. 131-159). Cambridge: Cambridge University Press.

Open Access This chapter is licensed under the terms of the Creative Commons Attribution 4.0 International License (http://creativecommons.org/licenses/by/4.0/), which permits use, sharing, adaptation, distribution and reproduction in any medium or format, as long as you give appropriate credit to the original author(s) and the source, provide a link to the Creative Commons licence and indicate if changes were made.

The images or other third party material in this chapter are included in the chapter's Creative Commons licence, unless indicated otherwise in a credit line to the material. If material is not included in the chapter's Creative Commons licence and your intended use is not permitted by statutory regulation or exceeds the permitted use, you will need to obtain permission directly from the copyright holder.

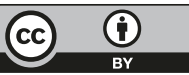




\section{Correction to: Youth Transitions among Descendants of Turkish Immigrants in Amsterdam and Strasbourg:}

\section{Correction to:}

E. Keskiner, Youth Transitions among Descendants of Turkish

Immigrants in Amsterdam and Strasbourg:, IMISCOE

Research Series, https://doi.org/10.1007/978-3-030-11790-0

This book was inadvertently published with incorrect affiliation of the author

"Elif Keskiner". It has now been updated as: Department of Sociology, Vrije Universiteit, Amsterdam, The Netherlands 